Universidade de Brasília - UnB

Instituto de Geociências - IG

Programa de Pós-Graduação em Geologia

\title{
PETROGRAFIA, GEOQUÍMICA E GEOCRONOLOGIA DAS ROCHAS METAVULCÂNICAS E METAPLUTÔNICAS DOS GREENSTONE BELTS FAINA E SERRA DE SANTA RITA: IMPLICAÇÕES PARA O AMBIENTE TECTÔNICO
}

Dissertação de Mestrado no 361

Caio César Aguiar Borges

Orientadora: Profa. Dra. Catarina L.B. Toledo

Co-orientadora: Profa. Dra. Adalene Moreira Silva 


\section{PETROGRAFIA, GEOQUÍMICA E GEOCRONOLOGIA DAS ROCHAS METAVULCÂNICAS E METAPLUTÔNICAS DOS GREENSTONE BELTS FAINA E SERRA DE SANTA RITA: IMPLICAÇÕES PARA O AMBIENTE TECTÔNICO}

Dissertação de mestrado elaborada junto ao curso de Pós-Graduação em Geologia (Área de concentração em Geologia Regional), Instituto de Geociências, Universidade de Brasília, como requisito parcial para a obtenção do título de Mestre em Geologia.

Orientadora: Prof. Dra. Catarina L.B. Toledo Co-orientadora: Profa. Dra. Adalene Moreira Silva

Banca examinadora:

Prof. Dra. Catarina L.B. Toledo (Presidente)

Prof. Dr. Elson Paiva de Oliveira (IG-UNICAMP)

Prof. Dr. César Fonseca Ferreira Filho (IG-UnB)

Prof. Dr. Nilson Francisquini Botelho (IG-UnB) (Suplente) 


\title{
FICHA CATALOGRÁFICA
}

\author{
Borges, Caio César Aguiar
}

Petrografia, geoquímica e geocronologia das rochas metavulcânicas e metaplutônicas dos greenstone belts Faina e Serra de Santa Rita: implicações para o ambiente tectônico, 2016.

$\mathrm{N}^{\circ}$ de páginas: 121

Área de concentração: Geologia Regional

Orientadora: Prof. Dra. Catarina L.B. Toledo 
"No matter where you go, there you are" 


\section{Agradecimentos}

Agradeço primeiramente a Deus.

Agradeço aos meus pais, Divino Borges e Luciene Aguiar, e a minha irmã, Suellen, por todo o apoio, dedicação, ensinamentos e advertências, e por serem meu grande exemplo de sucesso.

Agradeço as minhas orientadoras, Catarina e Adalene, pela confiança, motivação, apoio, paciência e amizade, e por me ajudarem a crescer como aluno e como pessoa.

Agradeço aos professores Hardy, Farid e Jeremie, pelas contribuições a este trabalho e pelas enriquecedoras discussões geológicas.

Agradeço a todos os professores e funcionários do Instituto de Geociências da UnB.

Agradeço a todos os participantes do TF-2014, por todas as contribuições, amizades e parcerias durante o campo.

Agradeço a todos os meus grandes amigos da Geologia.

Agradeço ao CNPq, pela bolsa de mestrado. 


\section{Resumo}

O Terreno Arqueano-Paleoproterozóico de Goiás é um fragmento alóctone da Província Tocantins que foi amalgamado na margem oeste da Faixa Brasília durante o Ciclo Brasiliano. O terreno é composto por uma associação de complexos granito-gnáissicos (TTG) arqueanos e greenstone belts arqueanos a paleoproterozóicos. Os greenstone belts Faina e Serra de Santa Rita localizam-se na porção sul do terreno e são separados pela Falha de Faina. Estes cinturões são compostos por sequências inferiores de rochas metavulcânicas ultramáficas sobrepostas por metabasaltos e sequências superiores de rochas metassedimentares. Os metabasaltos correspondem a anfibolitos restritos ao greenstone belt Serra de Santa Rita e estão associados a lentes de metandesito e intrusões dioríticas a tonalíticas poli-deformadas. O conjunto foi metamorfizado em condições de fácies anfibolito e afetado por retrometamorfismo em fácies xisto verde. O presente trabalho investiga as assinaturas geoquímicas e isotópicas das rochas metavulcânicas e metaplutônicas dos greenstone belts Faina e Serra de Santa Rita com o objetivo de estabelecer os diferentes períodos de magmatismo e o ambiente tectônico de formação destas sequências. Os dados indicam que as rochas ultramáficas apresentam algumas características químicas semelhantes aos boninitos modernos. Os anfibolitos são divididos em dois grupos: basaltos do tipo 1 e basaltos do tipo 2. Os basaltos do tipo 1 são toleíticos e se assemelham aos basaltos de bacias de back-arc. Os basaltos do tipo 2 apresentam elevados teores de $\mathrm{Nb}$ (5-12 ppm) e se assemelham aos basaltos enriquecidos em $\mathrm{Nb}$ (Nb-enriched basalts; $N E B)$ que ocorrem em associação com adakitos em alguns arcos de ilhas fanerozóicos e que também já foram reportados em alguns greenstone belts arqueanos. Os metandesitos, metadioritos e metatonalitos apresentam algumas das principais características químicas diagnósticas dos adakitos, incluindo os baixos valores de $\mathrm{Yb}$ (0,7-1,6 ppm), Y (8-17 ppm) e fracionamento de ETR pesados $\left(\mathrm{La} / \mathrm{Yb}_{\mathrm{cn}}=7-19\right)$. Os metandesitos e metatonalitos são caracterizados por teores mais elevados de $\mathrm{SiO}_{2}(56-68 \%)$ e se assemelham aos adakitos de alta-silica (High-SiO adakites; HSA), ao passo que os metadioritos são caracterizados por menores teores de $\mathrm{SiO}_{2}$ (54-58\%) e teores muito elevados de $\mathrm{MgO}$ (9-15\%), Cr (440-1060 ppm) e Ni (231-473 ppm), se assemelhando aos adakitos de baixa-sílica ( $\mathrm{Low}-\mathrm{SiO}_{2}$ adakites; LSA) ou andesitos magnesianos (high-Mg andesites; HMA). As datações LA-ICP-MS U-Pb em zircão registram dois períodos principais de atividade ígnea na região: 2,96-2,92 $\mathrm{Ga}$ e 2,79 $\mathrm{Ga}$. As rochas cristalizadas no primeiro período $(2,96-2,92 \mathrm{Ga})$ apresentam $\mathrm{T}_{\mathrm{DM}}$ entre 3,08 e 2,99 Ga e $\mathrm{eNd}_{\mathrm{N}}(\mathrm{t})$ entre 2,16 e 2,77, indicando assinatura juvenil e ausência de contaminação com crosta siálica mais antiga nestes magmas. A amostra de metatonalito cristalizada em 2,79 Ga apresenta $\mathrm{T}_{\mathrm{DM}}$ 
de $3,13 \mathrm{Ga} e_{\varepsilon N d}(\mathrm{t})$ inicial igual a -0,30, indicando a influência de contribuição crustal neste segundo período. Os dados sugerem que os protólitos vulcânicos e plutônicos dos greenstone belts Faina e Serra de Santa Rita estão inseridos em um sistema forearc-arc-back-arc intraoceânico. O estágio inicial, em torno de 2,96 Ga, corresponde à geração de lavas ultramáficas em um ambiente de forearc nos estágios iniciais de evolução de um arco de ilhas, de maneira análoga aos boninitos modernos, porém sob elevadas taxas de fusão parcial de um manto hidratado no Arqueano. A evolução do arco e progressão da subducção possibilitou a fusão parcial da placa oceânica subductada e geração de adakitos. A fusão parcial do manto residual que foi previamente metassomatizado com o magma adakítico gerou os basaltos enriquecidos em $\mathrm{Nb}$. A fusão parcial do manto por descompressão gerou derrames basálticos toleíticos na região de back-arc. Em torno de 2,92 Ga, o magma adakítico foi totalmente consumido na reação metassomatica com o manto e a posterior fusão parcial deste manto hibridizado gerou magmatismo andesítico com altos teores de $\mathrm{MgO}, \mathrm{Cr}$ e Ni que se alojou na crosta na forma de intrusões dioríticas. O estágio tardio corresponde à formação de arco continental em torno de 2,79 Ga, marcado pela geração de tonalitos e amalgamação com outros arcos de ilhas e continentais que constituem os complexos Caiçara e Uvá para formar o substrato arqueano da porção sul do Terreno Arqueano-Paleoproterozóico de Goiás.

Palavras-chave: Província Tocantins, Terreno Arqueano-Paleoproterozóico de Goiás, Greenstone belt Faina, Greenstone belt Serra de Santa Rita, Adakitos, Basaltos enriquecidos em $\mathrm{Nb}$. 


\section{Abstract}

The Archean-Paleoproterozoic Terrane of Goiás is an allochthonous fragment of Archean-Paleoproterozoic crust that is a part of the Tocantins Province and was amalgamated to the west margin of the Brasilia Belt during the Neoproterozoic Brasiliano orogeny. The terrane comprises an association of Archean granite-gneisses complexes (TTG) and Archean to Paleoproterozoic greenstone belts. The Faina and Serra de Santa Rita greenstone belts are located in the southern portion of the terrane and are separated by the Faina Fault. These belts are composed of lower metavolcanic sequences that comprise basal ultramafic rocks interpreted as metakomatiites overlain by metabasalts and metasedimentary sequences. The metabasalts correspond to amphibolites restricted to the Serra de Santa Rita greenstone belt and are associated with metandesite lenses and dioritic to tonalitic polydeformed intrusions. These rocks were metamorphosed under amphibolite facies and submitted to greenschist facies retrometamorphism. This work investigate the geochemical and isotopic signatures of the metavolcanic and metaplutonic rocks of the Faina and Serra de Santa Rita greenstone belts aiming to establish the different periods of magmatism and the tectonic enviroment of these sequences. Our data indicate that the ultramafic rocks present some similar chemical characteristics to modern boninites. The amphibolites are subdivided into two groups: The type 1 basalts and the type 2 basalts. The type 1 basalts are tholeiites similar to back-arc basin basalts (BABB). The type 2 basalts have high Nb contents (5-12 ppm) and resemble Nb-enriched basalts (NEB) that occur associated with adakites in some hot Phanerozoic island arcs and were also reported in some Archean greenstone belts. The metandesites, metadiorites and metatonalites show some of the main chemical diagnostic features of adakites, including low Yb (0.7-1.6 ppm), Y (8-17 ppm) and fractionation of HREE $\left(\mathrm{La} / \mathrm{Yb}_{c n}=7-19\right)$. The metandesites and metatonalites are characterized by higher $\mathrm{SiO}_{2}$ contents (56-68\%) and resemble high-SiO ${ }_{2}$ adakites (HSA), while the metadiorites have lower $\mathrm{SiO}_{2}$ (54-58\%) and very high $\mathrm{MgO}$ (9-15\%), $\mathrm{Cr}$ (440-1060 ppm) and $\mathrm{Ni}$ (231-473 ppm) contents, resembling low-SiO ${ }_{2}$ adakites (LSA) or high-Mg andesites (HMA). LA-ICP-MS U$\mathrm{Pb}$ zircon dating show two main periods of igneous activity: 2.96-2.92 $\mathrm{Ga}$ and $2.79 \mathrm{Ga}$. The rocks crystallized in the first period (2.96-2.92 $\mathrm{Ga}$ ) show $T_{D M}$ between 3.08 and $2.99 \mathrm{Ga}$, and $\varepsilon N d(t)$ between 2.18 and 2.77, indicating juvenile magmatic signatures and absence of older sialic crust contamination. A metatonalite sample crystallized at 2.79 Ga shows $T_{D M}$ of 3.13 Ga and $\varepsilon_{E d}(t)$ of -0.30 , indicanting crustal contribution in this second period. The data suggest that the volcanic and plutonic protholiths of the Faina and Serra de Santa Rita greenstone belts are inserted into an intraoceanic forearc-arc-back-arc system. The initial 
stage corresponds to the eruption of ultramafic lava in the forearc region of a proto-island arc, at $2.96 \mathrm{Ga}$. The evolution of the island arc and subduction progression led to oceanic slab-melting and adakite generation. Melting of the residual mantle that was previously metasomatized by adakitic melt generated Nb-enriched basalts. Decompression mantle melting at the back-arc region generated tholeiite flows. At $2.92 \mathrm{Ga}$, the adakitic melt was totally consumed by peridotite mantle and the subsequent melting of these hybridized mantle wedge generated high-Mg andesites that lodged in the crust as dioritic intrusions with high $\mathrm{MgO}, \mathrm{Cr}$ and $\mathrm{Ni}$ contents. The late stage corresponds to a continental arc formation at 2.79 $G a$, marked by tonalitic magmatism and amalgamation with other island and continental arcs that constitute the Uvá and Caiçara TTG complexes to form the Archean substrate of the southern portion of the Archean-Paleoproterozoic Terrane of Goiás.

Keywords: Tocatins Province, Archean-Paleoproterozoic Terrane of Goiás, Faina greenstone belt, Serra de Santa Rita greenstone belt, Adakites, Nb-enriched basalts. 


\section{SUMÁRIO}

Agradecimentos

Resumo

Abstract

\section{CAPÍTULO I - INTRODUCÃ̃}

1. Apresentação

2. Objetivos da dissertação

3. Estruturação da dissertação

4. Síntese da geologia do Terreno Arqueano-Paleoproterozóico de Goiás

4.1. Contexto geológico

4.2. Os complexos TTG

4.3. Os greenstone belts

4.3.1. Estratigrafia

4.3.2. Sequências metavulcânicas

4.3.3. Sequências metassedimentares

4.3.4. Geocronologia e isótopos de carbono em metadolomitos

4.4. Intrusões paleoproterozóicas e influências do Ciclo Brasiliano

CAPÍTULO II - GEOCHEMISTRY AND ISOTOPIC SIGNATURES OF METAVOLCANIC AND METAPLUTONIC ROCKS OF THE FAINA AND SERRA DE SANTA RITA GREENSTONE BELTS, CENTRAL BRAZIL: EVIDENCES FOR A MESOARCHAEAN INTRAOCEANIC ARC

ABSTRACT

1. Introduction

2. Geological setting

2.1. The Archean-Paleoproterozoic Terrane of Goiás 24

2.1.1. The TTG complexes $r$

$\begin{array}{lr}\text { 2.1.2. The greenstone belts } & 26\end{array}$

2.1.3. The Faina and Serra de Santa Rita greenstone belts 27

3. Sampling and analytical methods $\quad 30$

$\begin{array}{lr}\text { 3.1. Sampling } & 30\end{array}$

3.2. Eletron microprobe analyses $\quad 30$

$\begin{array}{lr}\text { 3.3. Whole rock geochemistry } & 30\end{array}$

3.4. U-Pb geochronology $\quad 31$

$\begin{array}{lr}\text { 3.5. Sm-Nd isotopes } & 32\end{array}$

4. Field aspects and petrography $\quad 32$

4.1. Ultramafic rocks and chloritites $\quad 32$

$\begin{array}{lr}\text { 4.2. Amphibolites } & 33\end{array}$

4.3. Metandesites $\quad 34$

4.4. Metadioritesand metatonalites $\quad 34$

5. Whole rock geochemistry $\quad 37$

$\begin{array}{ll}\text { 5.1. Major and trace elements } & 37\end{array}$

5.1.1. Ultramafic rocks and chloritites $\quad 37$

$\begin{array}{lr}\text { 5.1.2. Amphibolites } & 38\end{array}$

$\begin{array}{lr}\text { 5.1.3. Metandesites } & 41\end{array}$

5.1.4. Metadioritesand metatonalites $\quad 42$

\begin{tabular}{lr} 
6. Geochronology & 43 \\
\hline
\end{tabular}

6.1. $\mathrm{U}-\mathrm{Pb} \quad 23$

\begin{tabular}{lr} 
6.2. $\mathrm{Sm}-\mathrm{Nd}$ & 45 \\
\hline
\end{tabular}

7. Discussions $\quad 45$

7.1. Element mobility and crustal contamination $\quad 45$

7.2. Origin of the ultramafic rocks and similarities with boninites 46

$\begin{array}{ll}\text { 7.3. Origin of the chloritites } & 48\end{array}$

7.4. Type 1 basalts: back-arc basin basalts $(B A B B) \quad 49$

7.5. Type 2 basalts: Nb-enriched basalts (NEB)

7.6. Correlations between the metandesites, metadiorites and metatonalites with adakite and 54

high-Mg andesites

$\begin{array}{lr}\text { 8. Geodynamic setting } & 58\end{array}$

\begin{tabular}{lr} 
9. Conclusions & 61 \\
\hline 10. Appencix
\end{tabular}

10. Appendix $\quad 63$

10.1. Coordinates of the samples used in this study $\quad 63$

10.2. Summary of eletron micropobe analyses data 65 


\section{ÍNDICE DE FIGURAS}

Fig. i. Localização e principais subdivisões da Faixa Brasília. O Terreno Arqueano-Paleoproterozóico de Goiás está localizado na porção centro-oeste da faixa. Adaptado de Pimentel et al. (2000).

Fig. ii. Localização e principais componentes do Terreno Arqueano-Paleoproterozóico de Goiás. Adaptado de Jost et al. (2014).

Fig. iii. Mapas geológicos dos greenstone belts da porção norte do Terreno Arqueano-Paleoproterozóico de Goiás. (A) Greenstone belt Crixás. (B) Greenstone belt Guarinos. (C) Greenstone belt Pilar de Goiás. Adaptado de Jost et al. (2014).

Fig. iv. Mapa geológico dos greenstone belts Faina e Serra Santa Rita, porção sul do Terreno Arqueano-Paleoproterozóico de Goiás. Adaptado de Baeta et al. (2000) e Toledo et al. (2014).

Fig. v. Colunas estratigráficas dos greenstone belts do Terreno Arqueano-Paleoproterozóico de Goias. Adaptado de Jost et al. (2014).

Fig. 1. Location of the Brasilia Belt and its main components. The Archean-Paleoproterozoic Terrane of Goiás is located in the midwestern portion of the Brasilia Belt (Modified after Pimentel et al., 2004).

Fig. 2. The Archean Paleoproterozoic Terrane of Goiás and the Faina and Serra de Santa Rita greenstone belts, located in the southern portion of the terrane. (A) Location of the Archean-Paleoproterozoic Terrane of Goiás in the Brasilia Belt. (B) Distribution of the TTG complexes and greenstone belts that constitute the ArcheanPaleoproterozoic Terrane of Goiás; the Faina and Serra de Santa Rita greenstone belts are highlighted. (C) Geological map of the Faina and Serra de Santa Rita greenstone belts (Modified after Baeta et al., 2000 and Toledo et al., 2014).

Fig. 3. Field characteristics of metavolcanic and metaplutonic rocks of the Faina and Serra de Santa Rita greenstone belts. (A) Pillow lavas in ultramafic rocks. (B) Foliated amphibolite outcrop. (C) Foliated metandesite outcrop. (D) Intercalation of metachert and carbonaceous schist that are associated with metandesites and metavolcanoclastic rocks. (E) Angular finegrained mafic enclave in coarse-grained metadiorite. $(F)$ Intrusive contact between metadiorite (upper) and amphibotite (lower).

Fig. 4. Photomicrographs of metavolcanic and metaplutonic rocks of the Faina and Serra de Santa Rita greenstone belts. (A) Tremolite porphyroblasts in ultramafic schist composed of tremolite, chlorite and talc. (B) Pseudomorphs of olivine totally serpentinized and encompassed by Mg-hornblende and tremolite. (C-D) Amphibolite composed of Mg-hornblende partially substituted by actinolite and chlorite, and plagioclase replaced by epidote. (E) Metandesite with preserved plagioclase phenocrysts encompassed by a fine-grained matrix of quartz, plagioclase, muscovite and biotite. $(F)$ Metadiorite composed of $M g$-hornblende, plagioclase and quartz with preserved integranular texture. Crossed polarized lights: $A, B, D, E$ and $F$. Plane polarized lights: D. Abreviations: Ac (actinolite); Chl (chlorite); Ep (epidote); Hbl (hornblende); Mt (magnetite); Pl (plagioclase); $Q z$ (quartz); $\operatorname{Tr}$ (tremolite).

Fig. 5. Chondrite and primitive mantle-normalized diagrams for ultramafic rocks and chloritites of the Faina and Serra de Santa Rita greenstone belts. (A-B) Ultramafic schists and cumulate-textured rocks. (C-D) Chloritites. Normalization values and N-MORB composition are those of Sun and McDonough (1989).

Fig. 6. Classification diagrams for metavolcanic and metaplutonic rocks of the Faina and Serra de Santa Rita greenstone belts. (A) Nb/Y vs. Zr/Ti classification diagram (Winchester and Floyd, 1977). (B-C) Y vs. Zr and Yb vs. La discriminant diagrams of magmatic affinity (Ross and Bédard, 2009). 
Fig. 7. Chondrite and primitive mantle-normalized diagrams for amphibolites of the Faina and Serra de Santa Rita greenstone belts. (A-B) Amphibolites of the type 1 basalts group. (C-D) Amphibolites of the type 2 basalts group. Normalization values and N-MORB composition are those of Sun and McDonough (1989).

Fig. 8. Chondrite and primitive mantle-normalized diagrams for metandesites, metadiorites and metatonalites of the Faina and Serra de Santa Rita greenstone belts. (A-B) Metandesites. (C-D) Metadiorites and metatonalites. Normalization values and N-MORB composition are those of Sun and McDonough (1989).

Fig. 9. LA-ICP-MS U-Pb zircon ages of metavolcanic and metaplutonic rocks of Faina and Serra de Santa Rita greenstone belts. (A) TF14-I-099 (chloritite of the Faina greenstone belt). (B) TF14-XI-016 (chloritite of the Serra de Santa Rita greenstone belt). (C) TF14-XII-178 (amphibolite of the type 2 basalts group). (D) PFG-CA04A (metadiorite) and (E) TF14XII-183 (metatonalite).

Fig. 10. Tectonic discriminant diagrams for metavolcanic and metaplutonic rocks of the Faina and Serra de Santa Rita greenstone belts. (A) Nb/Yb vs. Th/Yb diagram (Pearce, 2008). Dotted fields represent tholeiitic (TH), calc-alkaline (CA) and shoshonitic rocks of convergent margins. Phanerozoic arc, back-arc and forearc fields are those of Matcalf and Shevais (2008). (B) Ta/Yb vs. Th/Yb diagram (Pearce, 1982, 2003). Dotted fields represent tholeiitic (TH) and calc-alkaline (CA) lavas of modern subduction zones.

Fig. 11. Th/Nb vs. Ce/Nb discriminat diagram (modified after Saunders et al., 1988 and Khanna et al., 2015) for amphibolites of the type 1 basalts group of the Serra de Santa Rita greenstone belt; these rocks plot in the Phanerozoic Mariana back-arc basalts field (BABB; Pearce et al., 2005). Abreviations: DMM (depleted MORB mantle component); SDC (subduction zone component).

Fig. 12. Discriminant diagrams distinguishing Nb-enriched basalts (NEB) from classical volcanic arc basalts for the amphibolites of the Serra de Santa Rita greenstone belt. (A) Nb vs. Nb/U diagram (Kepezhinskas et al., 1996). (B) MgOvs. $\mathrm{Nb} /$ La diagram (Kepezhinskas et al., 1996). (C) TiO2 vs.P2O5 diagram (Defant et al., 1992). The amphibolites of the type 1 basalts group plot outside the NEB field on diagrams. The amphibolites of the type 2 basalts group plot in the NEB field on $\mathrm{MgO}$ vs. $\mathrm{Nb} / \mathrm{La}$ and $\mathrm{Nb}$ vs. $\mathrm{Nb} / \mathrm{U}$ diagrams, while on TiO2 vs.P2O5 diagram, these rocks plot outside.

Fig. 13. Discriminant diagrams distinguishing adakites from classical island arc volcanic rocks $(A-B)$ and highSiO2 adakites from low-SiO2 adakites $(C-D)$ for the metandesites, metadiorites and metatonalites of the Serra de Santa Rita greenstone belt. (A) Y vs. Sr/Y diagram (Defant and Drummond, 1990). (B) Ycn vs. La/Ybcn diagram (Martin, 1987, 1999). (C) SiO2 vs $\mathrm{MgO}$ diagram (Martin et al., 2005). (D) SiO2 vs Nb diagram (Martin et al., 2005). The rocks plot predominantly in the adakite fields on $Y$ vs. Sr/Y and Ycn vs. La/Ybcn diagrams. The metandesites and metatonalite plot predominantly in the HAS fields on $\mathrm{SiO} 2$ vs $\mathrm{MgO}$ and $\mathrm{SiO} 2$ vs $\mathrm{Nb}$ diagrams,

Fig. 14. Geodynamic setting evolution stages proposed for the Faina and Serra de Santa Rita greenstone belts. The volcanic and plutonic rocks are inserted into an island arc evolution at 2.96-2.92 Ga and continental arc at $2.79 \mathrm{Ga}$. The Uvá and Caiçara complexes are represented by their oldest TTG rocks $(\sim 3.1 \mathrm{Ga})$. 


\section{ÍNDICE DE TABELAS}

Table 1. Coordinates of the samples of metavolcanic and metaplutonic rocks of the Faina and Serra de Santa Rita greenstone belts that were used for microprobe analyses, whole rock geochemistry and isotopic studies. Datum: WGS 84/UTM zone 22S.

Table 2.1. Amphibole composition data obtained from eletron micropobe analyses (wt. \%).

Table 2.2. Chlorite composition data obtained from eletron micropobe analyses (wt. \%).

Table 2.3. Plagioclase composition data obtained from eletron micropobe analyses (wt. \%).

Table 3. Major element (wt.\%) and trace-element (ppm) data for metavolcanic and metaplutonic rocks of the Faina and Serra de Santa Rita greenstone belts.

Table 4.1. Summary of U-Pb zircon data of sample TF14-I-099 (chloritite of the Faina greenstone belt) obtained by LA-SFICP-MS method.

Table 4.2. Summary of U-Pb zircon data of sample TF14-XI-016 (chloritite of the Serra de Santa Rita greenstone belt) obtained by LA-MS-ICP-MS method.

Table 4.3. Summary of U-Pb zircon data of sample TF14-XII-178 (amphibolite of the Serra de Santa Rita greenstone belt) obtained by LA-SF-ICP-MS method.

Table 4.4. Summary of U-Pb zircon data of sample PFG-CA-004A (metadiorite of the Serra de Santa Rita greenstone belt) obtained by LA-SF-ICP-MS method.

Table 4.5. Summary of U-Pb zircon data of sample TF14-XII-183 (metatonalite of the Serra de Santa Rita greenstone belt) obtained by LA-SF-ICP-MS method.

Table 5. Sm-Nd isotopic data of metavolcanic and metaplutonic rocks of the Serra de Santa Rita greenstone belt. 
CAPÍTULO I - INTRODUCÃ̃O 


\subsection{Apresentação}

O termo greenstone belt é usualmente utilizado para descrever terrenos alongados que consistem de rochas intrusivas e extrusivas de idade arqueana a proterozóica, composição ultramáfica a félsica, associadas a diferentes tipos de rochas metassedimentares (Furnes et al., 2015). Os greenstone belts são entidades geológicas extremamente variadas e complexas e registram múltiplos estágios de deformação, metamorfismo e metassomatismo. As pesquisas em greenstone belts têm crescido exponencialmente nas últimas décadas tendo em vista que estes terrenos fornecem valiosas informações em diversos tópicos das ciências naturais, como a evolução da litosfera, atmosfera, hidrosfera e biosfera da Terra primitiva. O conhecimento avançado nos terrenos granito-greenstones também tem sido fundamental na exploração mineral, pois importantes depósitos de ouro e metais base estão comumente associados (Anhaeusser, 2014).

Um importante pré-requisito para compreender como os crátons arqueanos foram construídos e amalgamados é entender o ambiente tectônico dos greenstone belts arqueanos. Embora a existência da tectônica de placas durante o Arqueano seja um dos assuntos mais debatidos das ciências da Terra, dados geoquímicos, geocronológicos e geofísicos associados a estudos experimentais sugerem que o sistema de tectônica de placas moderno operou desde o Arqueano (Calvert et al., 1995; Polat et al., 1998; Condie, 2000; Smithies et al. 2005; Benn et al., 2006; Cawood et al., 2006; Polat and Kerrich, 2006; Kusky et al., 2013). Assim, o ambiente geodinâmico dos greenstone belts pode ser interpretado em um contexto moderno de tectônica de placas a partir do estudo de sua paleogeografia, da estratigrafia e da assinatura geoquímica e isotópica das rochas vulcânicas e plutônicas associadas (Furnes et al., 2015).

O Terreno Arqueano-Paleoproterozóico de Goiás, localizado na porção centro-oeste do Estado de Goiás, é um fragmento alóctone de crosta arqueana-paleoproterozóica que foi amalgamado na margem oeste da Faixa Brasília durante o Ciclo Brasiliano (Jost et al., 2013). O terreno se extende por cerca de $18.000 \mathrm{~km}^{2}$ e é composto por uma associação de complexos granito-gnáissicos (TTG; tonalito-trondhjemito-granodiorito) e greenstone belts. Os TTG constituem cerca de $80 \%$ do terreno e são representados pelos complexos Anta, Caiamar, Moquém, Hidrolina, Caiçara e Uvá. Os greenstone belts constituem cerca de $20 \%$ do terreno e são representados na porção norte pelos greenstone belts Crixás, Guarinos e Pilar de Goiás, e na porção sul, pelos greenstone belts Faina e Serra de Santa Rita. As sequências supracrustais 
estão metamorfizadas em fácies xisto verde a anfibolito e hospedam importantes depósitos epigenéticos de ouro da região (Jost et al., 2014).

Os registros estratigráficos dos greenstone belts Faina e Serra de Santa Rita, porção sul do Terreno Arqueano-Paleoproterozóico de Goiás, compreendem seções metavulcânicas inferiores de metakomatiitos seguidos de metabasaltos e seções superiores de rochas metassedimentares (Danni et al., 1981, Resende et al., 1998). A reconstituição estratigráfica original destas sequências é complexa devido à superposição de diferentes eventos termotectônicos que promoveram adelgaçamento, espessamento e supressão de unidades geológicas (Jost et al., 2014). Os dados disponíveis sobre a região não são suficientes para a reconstrução detalhada do magmatismo e dos diferentes períodos de acreção crustal, e para a delineação do ambiente tectônico no qual as diferentes unidades foram formadas.

A proposta desta pesquisa é, portanto, analisar o ambiente tectônico de formação dos greenstone belts Faina e Serra de Santa Rita a partir do estudo das assinaturas geoquímicas e isotópicas das rochas metavulcânicas e metaplutônicas associadas. Pretende-se assim contribuir para a caracterização dos diferentes períodos de acreção crustal juvenil que precederam a formação dos sistemas orogênicos arqueanos envolvidos na formação do Terreno Arqueano-Paleoproterozóico de Goiás.

\section{Objetivos da dissertação}

O objetivo central desta dissertação é investigar e discutir o ambiente tectônico de formação dos greenstone belts Faina e Serra de Santa Rita com base no estudo das assinaturas geoquímicas e isotópicas das rochas metavulcânicas e metaplutônicas que compõem a base destas sequências.

Os objetivos específicos incluem:

1. Estudar a distribuição espacial e as características de campo das unidades metavulcânicas e metaplutônicas a partir de mapeamento geológico em escala 1:25.000 (Mapeamento realizado junto ao Trabalho Final de Graduação em Geologia de 2014, designado Projeto Faina-Goiás; Toledo et al., 2014);

2. Estudar a natureza das relações de contato entre os diferentes tipos de rochas metavulcânicas e metassedimentares, buscando estabelecer as relações estratigráficas originais dos greenstone belts; 
3. Caracterização petrográfica das rochas metavulcânicas e metaplutônicas com o intuito de identificar os protólitos das rochas e estudar as assembleias metamórficas diagnósticas dos diferentes eventos termo-tectônicos que afetaram a região de estudo;

4. Caracterização geoquímica e isotópica (U-Pb e $\mathrm{Sm}-\mathrm{Nd})$ das rochas metavulcânicas e metaplutônicas e integração com os demais dados geocronológicos disponíveis para a região visando o reconhecimento dos diferentes períodos de acreção crustal envolvidos na evolução da porção sul do Terreno Arqueano-Paleoproterozóico de Goiás.

\section{Estruturação da dissertação}

Esta dissertação de mestrado está estruturada em três partes principais: a primeira parte (Capítulo I) engloba a apresentação, objetivos principais do trabalho e uma síntese do conhecimento atual da geologia do Terreno Arqueano-Paleoproterozóico de Goiás. A segunda parte (Capítulo II) está organizada em formato de artigo intitulado "GEOCHEMISTRY AND ISOTOPIC SIGNATURES OF METAVOLCANIC AND METAPLUTONIC ROCKS OF THE FAINA AND SERRA DE SANTA RITA GREENSTONE BELTS, CENTRAL BRAZIL: EVIDENCES FOR A MESOARCHAEAN INTRAOCEANIC ARC”, onde são apresentados os materiais e métodos do trabalho, os resultados da pesquisa e as principais discussões. A terceira parte (Capítulo III) engloba uma síntese dos resultados e discussões obtidos na dissertação de mestrado, considerações finais e sugestões para trabalhos futuros.

\section{Síntese da geologia do Terreno Arqueano-Paleoproterozóico de Goiás}

\subsection{Contexto geológico}

A Província Tocantins (Almeida et al., 1981) representa um amplo orógeno Brasiliano/Pan-africano da Plataforma Sul-Americana, formado pela colisão entre os crátons Amazônico, São Francisco/Congo e Paranapanema (atualmente coberto por rocha fanerozóicas da Bacia do Paraná), que levou a amalgamação do supercontinente Gondwana Ocidental no Neoproterozóico. A província é constituída por três cinturões de dobramento: a Faixa Paraguai, na porção sudoeste, a Faixa Araguaia, na porção noroeste, e a Faixa Brasília, que contorna toda a margem oeste do Cráton do São Francisco (Fig. i) (Pimentel et al., 2000).

A Faixa Brasília pode ser dividida em um segmento norte, com direção estrutural dominante NE-SW, e um segmento sul, com direção NW-SE. A separação entre os segmentos é estabelecida pela Sintaxe dos Pirineus, que marca a mudança das direções estruturais e 
configura a superposição de estruturas do segmento norte ao segmento sul (Araújo Filho, 2000). Ambos os segmentos são divididos nas zonas externa e interna (Fig. i).

A zona externa é composta por espessas sequências de rochas sedimentares de margem passiva, metamorfizadas em baixo grau e seu embasamento, estruturadas em faixas de dobramentos e empurrões com vergência em direção ao cráton do São Francisco. A zona interna engloba: (1) um núcleo metamórfico do orógeno, conhecido como Complexo Granulítico Anápolis-Itauçu (Piuzana et al., 2003) e Complexo Uruaçu (DellaGiustina et al., 2009), rochas metassedimentares distais do Grupo Araxá (Seer et al., 2001) e fragmentos ofiolíticos (Strieder \& Nilson, 1992); (2) o Maciço de Goiás, composto principalmente por fragmentos cratônicos alóctones que constituem o Terreno Arqueano-Paleoproterozóico de Goiás (Jost et al., 2013), uma cobertura paleoproterozóica dobrada e metamorfizada e complexos máfico-ultramáficos acamadados com sequências metavulcanossedimentares associadas (Ferreira Filho et al., 1992; Ferreira-Filho et al., 1994; Moraes et al., 2000); e (3) o Arco Magmático de Goiás, de idade neoproterozóica, constituído por sequências metavulcanossedimentares e ortognaisses que representam uma vasta área de crosta juvenil e continental gerada durante a convergência de placas entre 900 e $630 \mathrm{Ma}$ (Pimentel et al., 1991, 1997; Pimentel and Fuck, 1992; Junges et al., 2002, 2003). A atividade ígnea no Arco Magmático de Goiás ocorreu em dois episódios: entre 890 e 800 Ma, em um contexto de arcos intraoceânicos; e entre 660 e 600 Ma, em ambiente de margem continental ativa no final do Ciclo Brasiliano (Laux et al., 2005).

O Terreno Arqueano-Paleoproterozóico de Goiás é um fragmento alóctone de crosta arqueana-paleoproterozóica que está localizado na porção central da Província Tocantíns e que foi amalgamado na margem oeste da Faixa Brasília durante o Ciclo Brasiliano (Jost et al., 2013). O terreno possui formato aproximadamente oval com direção NE-SW e seus limites com as unidades geológicas adjacentes são tectônicos (Jost et al., 2014). Os principais componentes do Terreno Arqueano-Paleoproterozóico de Goiás são complexos granitognáissicos (TTG), greenstone belts e intrusões tardias de idades variadas (Fig. ii). 


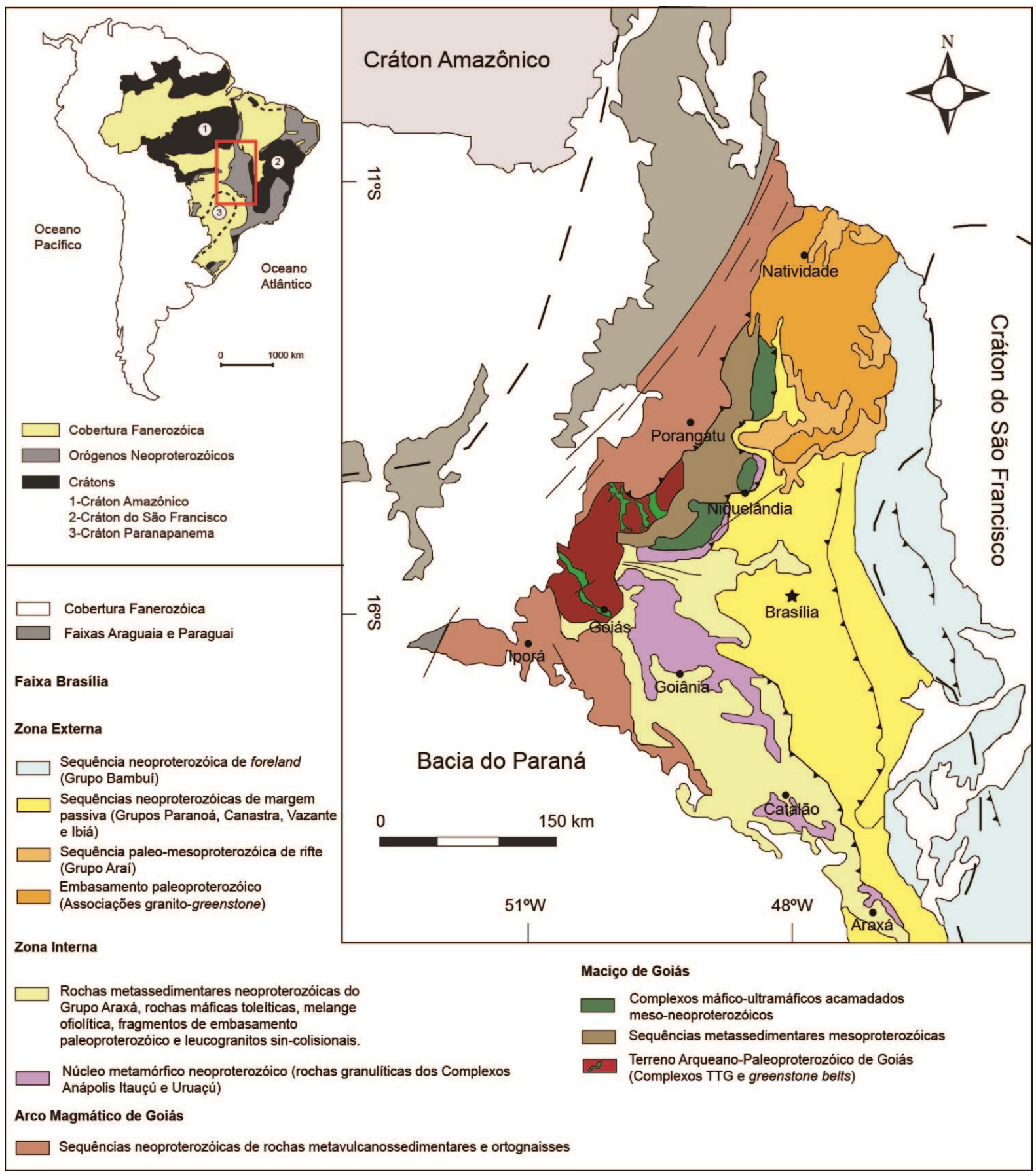

Fig. i. Localização e principais subdivisões da Faixa Brasília. O Terreno Arqueano-Paleoproterozóico de Goiás está localizado na porção centro-oeste da faixa. Adaptado de Pimentel et al. (2000). 


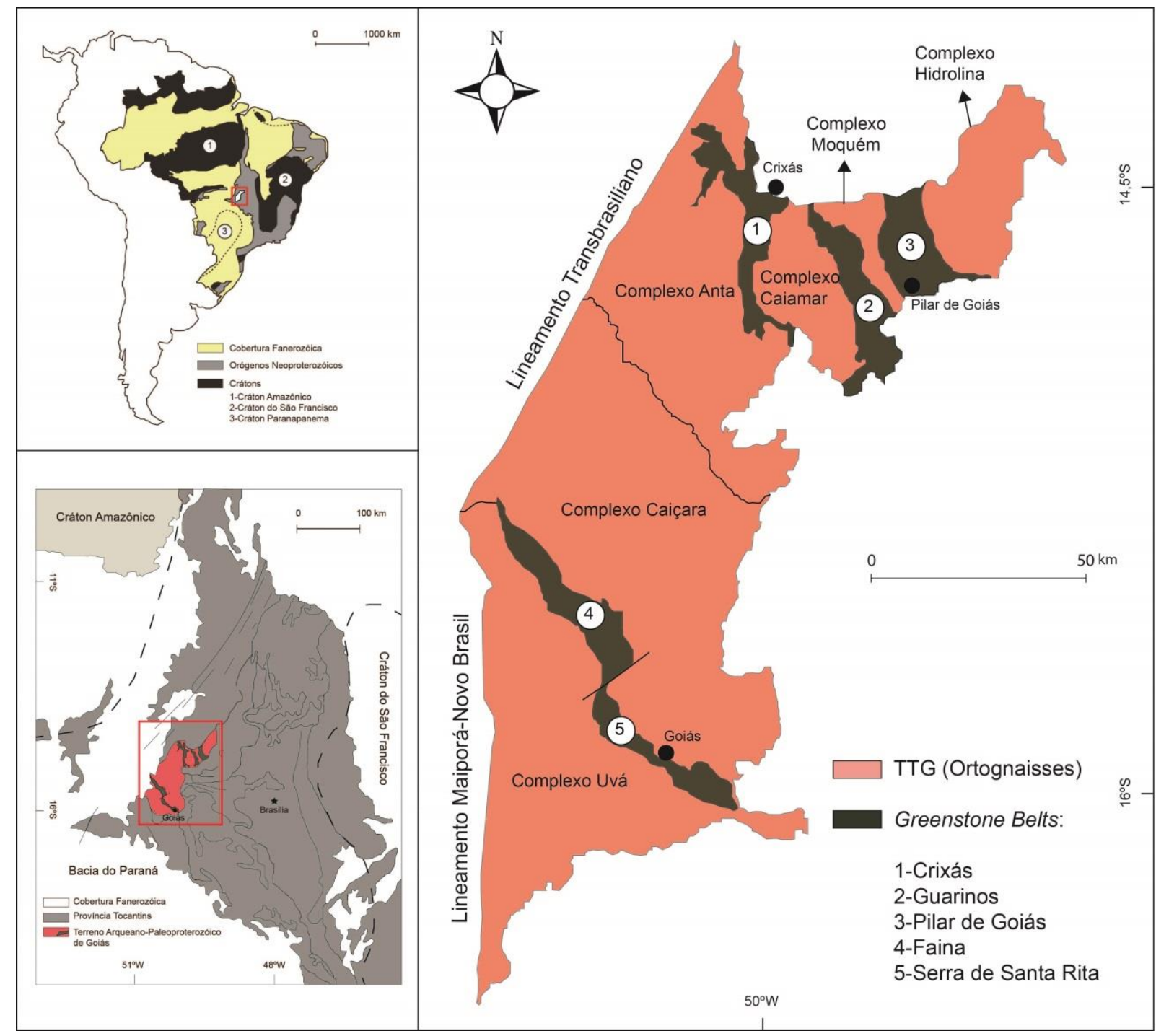

Fig. ii. Localização e principais componentes do Terreno Arqueano-Paleoproterozóico de Goiás. Adaptado de Jost et al. (2014).

\subsection{Os complexos $T T G$}

Os complexos TTG compreendem cerca de $80 \%$ do Terreno ArqueanoPaleoproterozóico de Goiás e consistem de ortognaisses tonalíticos a granodioríticos, subordidamente graníticos, reunidos em seis complexos que diferem no arranjo estrutural, associações litológicas e idades. Na porção norte do terreno, localizam-se os complexos Anta, Caiamar, Moquém e Hidrolina. Na porção sul, localizam-se os complexos Caiçara e Uvá (Fig. ii).

Os complexos TTG da porção norte estão divididos em dois estágios de granitogênese distintos. O primeiro estágio compreende ortognaisses de composição tonalítica a granodiorítica, subordinadamente granítica, que ocorrem nos complexos Hidrolina, Caiamar e 
na parte leste do complexo da Anta, com idades de cristalização U-Pb em zircão entre 2845 e 2785 Ma e valores de $\varepsilon_{\varepsilon d}$ iniciais entre $+2,41$ e -0,63. Cristais herdados de zircão de 3,15 a 3,3 Ga e idades-modelo Sm-Nd de 3,0 Ga indicam que estes magmas juvenis foram contaminados por crosta siálica mais antiga, da qual, até o presente, não há evidências de exposição (Queiroz et al., 2008). O segundo estágio de granitogênese está registrado no Complexo Moquém e compreende corpos tabulares foliados de granodiorito e granito com idades de cristalização entre 2711 e 2707 Ma. Os valores negativos de $\varepsilon$ d iniciais $(-2,00$ e -2,20) e cristais herdados de zircão do ciclo anterior indicam que estas rochas são de derivação crustal. Os dados de U-Pb em zircão não detectaram reciclagem isotópica durante o Paleoproterozóico e Neoproterozóico devido à atuação de processos sob temperatura inferior à da estabilidade isotópica do sistema U-Pb-Th no mineral (Queiroz et al., 2008).

O Complexo Caiçara, localizado na porção sul do terreno, é composto predominantemente por ortognaisses tonalíticos com idade de cristalização U-Pb em zircão de 3,14 Ga e idade-modelo Sm-Nd mínima de 3,1 Ga (Beghelli Junior, 2012). Os ortognaisses são intrudidos por corpos menores de granodiorito, granito e rochas da série charnockítica, com idades de cristalização U-Pb próximas de 2,8 Ga e idades-modelo Sm-Nd em torno de 2,9 Ga (Beghelli Junior, 2012). O Complexo Uvá, localizado no extremo meridional do terreno, é constituído por dois grupos de ortognaisses (Jost et al., 2005, 2013). O grupo dominante é o mais antigo e compreende ortognaisses polideformados de composição tonalítica a granodiorítica e um stock de diorito. Os ortognaisses tonalíticos apresentam idades de cristalização U-Pb em zircão entre 3040 e 2930 Ma (Jost et al., 2013). O stock de diorito apresentou idade U-Pb em zircão de $2934 \pm 5$ Ma (Pimentel et al., 2003). O segundo grupo corresponde a corpos tabulares de tonalito e monzogranito com idades de cristalização U-Pb em zircão entre 2764 e 2846 Ma (Jost et al., 2005, 2013). Portanto, o substrato arqueano da região é policíclico e os complexos TTG da porção sul do Terreno ArqueanoPaleoproterozóico de Goiás são mais antigos que os complexos TTG da porção norte.

\subsection{Os greenstone belts}

Os greenstone belts compreendem cerca de $20 \%$ do Terreno ArqueanoPaleoproterozóico de Goiás e ocorrem em cinco faixas estreitas e alongadas de comprimentos variáveis localizadas entre os complexos TTG (Fig. ii). Na porção norte do terreno, localizamse os greenstone belts Crixás, Guarinos e Pilar de Goiás (Fig. iii). Na porção sul, localizam-se os greenstone belts Faina e Serra de Santa Rita, que estão separados por uma falha direcional 
N $30^{\circ}$ E designada Falha de Faina (Fig. iv). O contato dos greenstone belts com os complexos TTG adjacentes é tectônico e a ocorrência, apesar de rara, de klippen nos ortognaisses indica que estas rochas supracrustais estão alóctones (Jost et al. 2005, 2013). Os registros estratigráficos dos cinco greenstone belts são compostos por seções inferiores de metakomatiitos sobrepostos por metabasaltos, e seções superiores de rochas metassedimentares. O conjunto de rochas foi submetido a metamorfismo em fácies xisto verde a anfibolito e a reconstituição estratigráfica original das faixas é complexa devido ao estado fragmentário, pela deformação policíclica, adelgaçamento, espessamento e a raridade de horizontes-guias, o que dificulta a correlação através das descontinuidades estruturais e ígneas (Jost et al., 2014).

Os greenstone belts do Terreno Arqueano Paleoproterozóico de Goiás possuem elevada importância econômica por hospedarem os significativos depósitos epigenéticos de ouro do Estado de Goiás e apresentarem potencial para depósitos singenéticos de ferro em formações ferríferas bandadas, ferro e manganês do tipo SEDEX, ouro do tipo VMS, ouro associado à albitito, paleoplacer aurífero e níquel e cobre sulfetado associado à metakomatiito. No entanto, os depósitos singenéticos potenciais ainda necessitam de estudos mais aprofundados na região (Jost et al., 2014). 

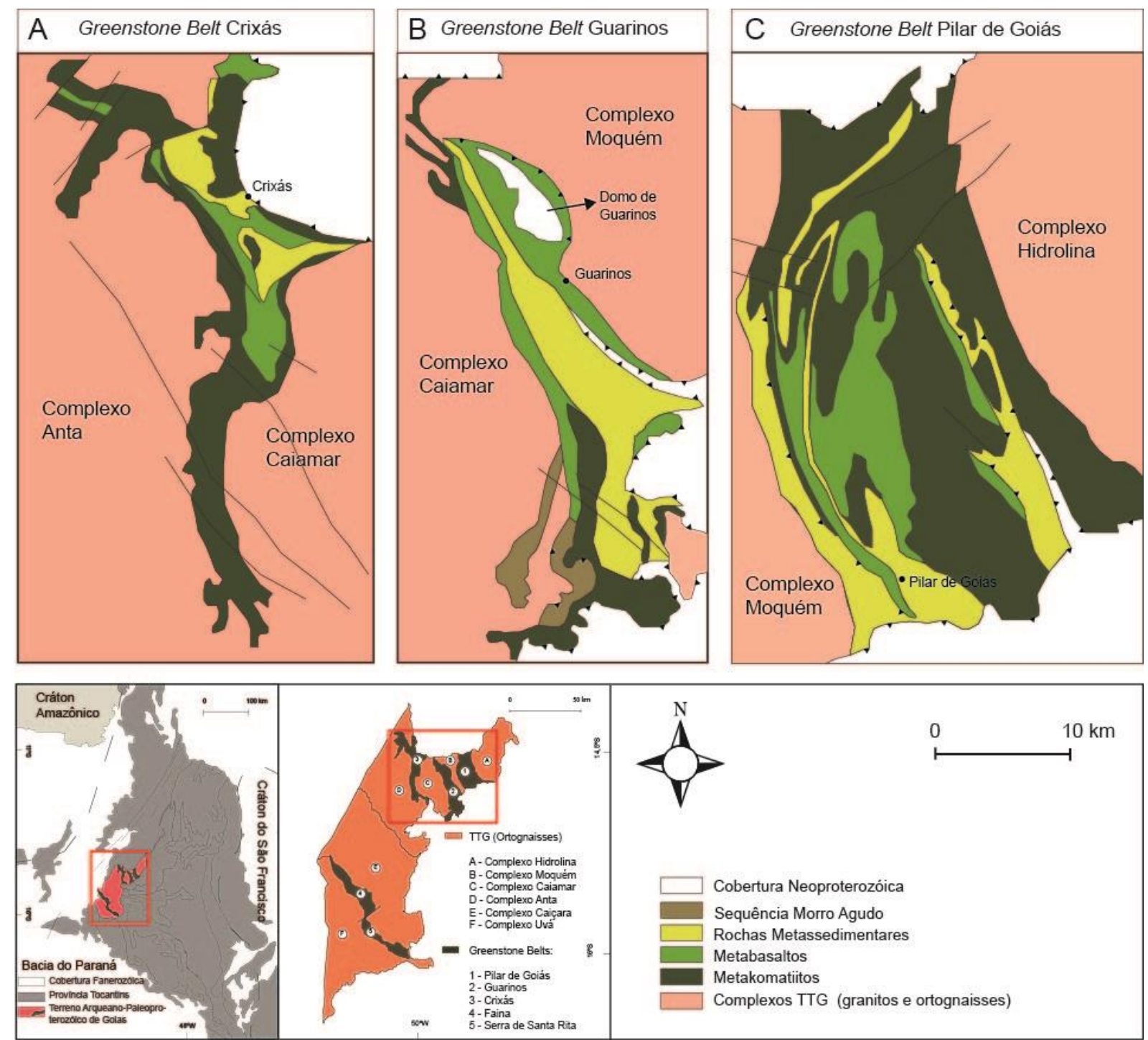

Fig. iii. Mapas geológicos simplificados dos greenstone belts da porção norte do Terreno ArqueanoPaleoproterozóico de Goiás. (A) Greenstone belt Crixás. (B) Greenstone belt Guarinos. (C) Greenstone belt Pilar de Goiás. Adaptado de Jost et al. (2014). 


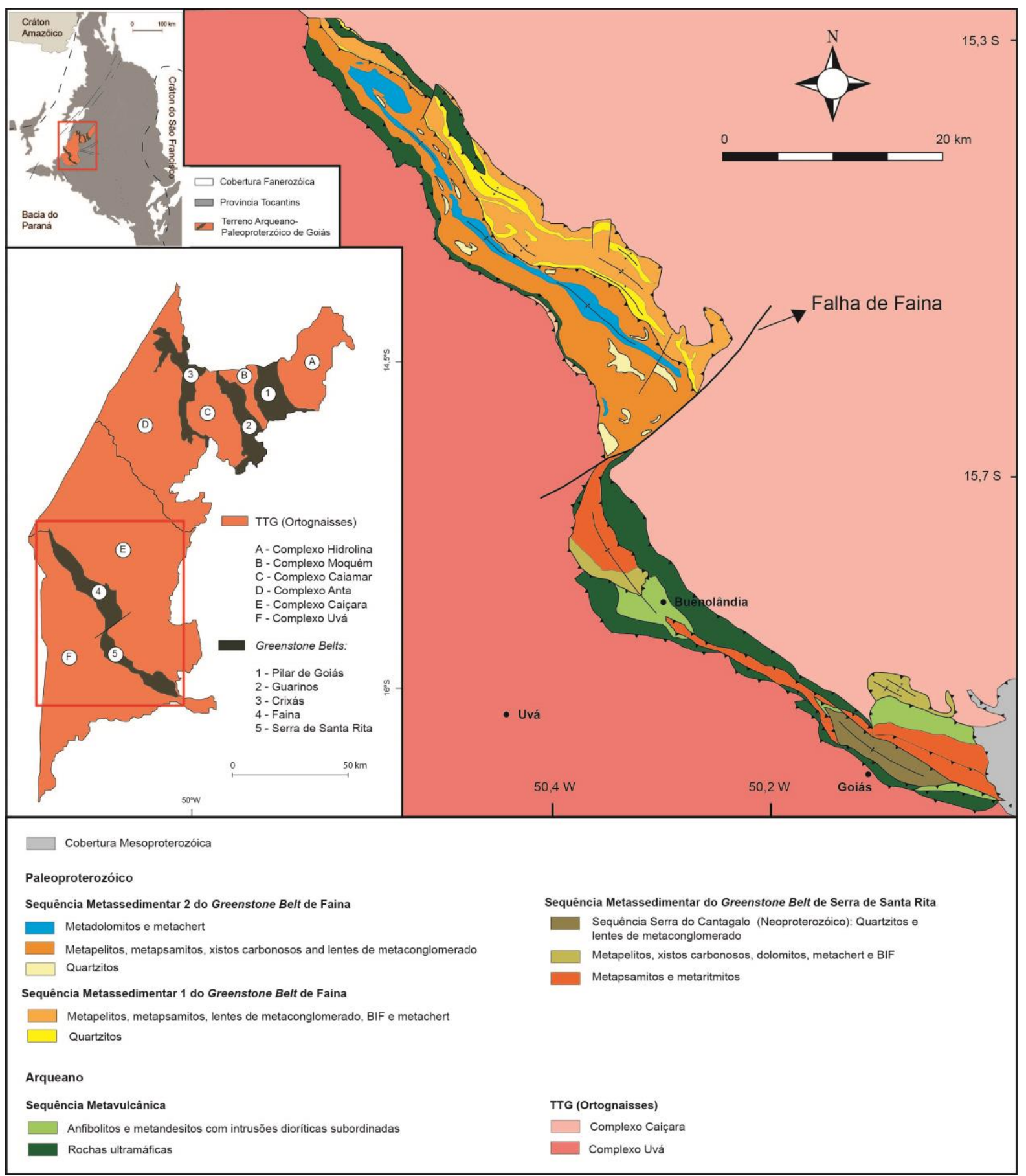

Fig. iv. Mapa geológico dos greenstone belts Faina e Serra Santa Rita, porção sul do Terreno ArqueanoPaleoproterozóico de Goiás. Adaptado de Baeta et al. (2000) e Toledo et al. (2014). 


\subsubsection{Estratigrafia}

O modelo estratigráfico inicial dos greenstone belts da porção norte do Terreno Arqueano-Paleoproterozóico de Goiás (greenstone belts Crixás, Guarinos e Pilar de Goiás) deve-se a Danni \& Ribeiro (1978), que reuniram as rochas metavulcanossedimentares da região no Grupo Pilar de Goiás, tendo por área-tipo o greenstone belt Pilar de Goiás. Sabóia (1979) subdivide este grupo, da base para o topo, nas formações Córrego Alagadinho, Rio Vermelho e Ribeirão das Antas, para designar, respectivamente, os metakomatiitos, metabasaltos e rochas metassedimentares, com adoção da Sequência Crixás como seção-tipo. Considerando as diferenças nos contrastes litológicos, ritmos de vulcanismo preservado de ambiente deposicional das seções sedimentares, Jost \& Oliveira (1991) propuseram considerar os três greenstone belts do norte como unidades independentes e criaram os grupos Crixás, Guarinos e Pilar de Goiás para reunir os respectivos conteúdos estratigráficos, com subdivisões em unidades formais.

Nos greentone belts da porção sul do terreno (greenstone belts Faina e Serra de Santa Rita), a primeira proposta estratigráfica deve-se a Danni et al. (1981) que subdividiram as faixas em uma sequência inferior (Sequência Serra de Santa Rita) composta de rochas metavulcânicas e metassedimentares interpretadas como arqueanas, e outra superior (Sequência Serra do Cantagalo) de rochas metassedimentares mais jovens, em discordância sobre a inferior. Teixeira (1981) propôs reunir as rochas sob o Grupo Goiás Velho, com uma unidade basal constituída por rochas metavulcânicas, incluindo metakomatiitos, metabasaltos e metavulcânicas félsicas e uma unidade superior metassedimentar, que inclui as rochas da Sequência Serra do Cantagalo de Danni et al. (1981). O autor também observou que as rochas supracrustais de ambas as faixas apresentavam algumas diferenças que permitiria desmembrálas no greenstone belt Goiás (sinônimo de greenstone belt Serra de Santa Rita) e no greenstone belt Faina, separados por uma falha dextral. Resende et al. (1998), tendo em vista que ambas as faixas possuem sequências metavulcânicas inferiores semelhantes, mas distintas sucessões metassedimentares superiores, propuseram o modelo estratigráfico atual para os greenstone belts Faina e Serra de Santa Rita. 


\subsubsection{Sequências metavulcânicas}

A base das colunas estratigráficas dos greenstone belts do Terreno ArqueanoPaleoproterozóico de Goiás é composta por metakomatiitos sobrepostos por metabasaltos. Os metakomatiitos caracterizam as formações Córrego Alagadinho (greenstone belt Crixás), Serra do Cotovelo (greenstone belt Guarinos), Córrego Fundo (greenstone belt Pilar de Goiás) e Manoel Leocádio (greenstone belts Faina e Serra de Santa Rita). Os metabasaltos estão reunidos nas formações Rio Vermelho (greenstone belt Crixás), Serra Azul (greenstone belt Guarinos), Cedrolina (greenstone belt Pilar de Goiás) e na Formação Digo-Digo (greenstone belts Faina e Serra de Santa Rita).

Os metakomatiitos preservam feições vulcânicas originais, tais como texturas spinifex, cumulática, estruturas de resfriamento rápido, brechas de fluxo e pillow lavas (Danni et al., 1981; Teixeira, 1981; Teixeira et al., 1981; Kuyumjian \& Teixeira, 1982; Danni et al., 1986; Profumo, 1993; Jost et al., 1995). Os metabasaltos compreendem derrames predominantemente toleííticos, por vezes almofadados e variolíticos. Localmente ocorrem diques e sills de dolerito e gabro. Formações ferríferas, gonditos e metachert podem ocorrer intercalados aos metakomatiitos e metabasaltos em proporções variadas. A variação nas proporções das intercalações de rochas metassedimentares químicas nas sequências metavulcânicas dos diferentes greenstone belts sugere que cada faixa retém ritmos distintos de vulcanismo ou estados de preservação disitintos (Jost et al., 2014). Rochas metavulcanoclásticas são descritas por Resende et al. (1998) no greenstone belt Serra de Santa Rita e são posicionadas na interface entre os metabasaltos e o pacote metassedimentar.

\subsubsection{Sequências metassedimentares}

As seções metassedimentares dos cinco greenstone belts do Terreno ArqueanoPaleoproterozóico de Goiás são significamente contrastantes. No greenstone belt Crixás as rochas metassedimentares compreendem a Formação Ribeirão das Antas, caracterizada por uma seção de metapelitos carbonosos de ambiente euxênico, com eventuais intercalações de metadolomitos, alguns oolíticos, e metabasaltos. A deposição dos pelitos foi progressiva e gradualmente sincrônica com grauvacas rítmicas, as quais passam a predominar no topo da seção metassedimentar (Jost \& Oliveira, 1991) (Fig. vA).

No greenstone belt Guarinos, o pacote metassedimentar se inicia com a Formação São Patricinho, composta por metarritmitos finos ricos em clorita. A presença de clastos de 
metabasalto sugere que esta unidade provavelmente foi formada a partir da erosão das rochas metavulcânicas sotopostas. Acima dos metabasaltos e metarritmitos ocorre a Formação Aimbé, composta por zonas de alteração hidrotermal com condutos exalativos e lentes de paraconglomerado sobrepostos por metargilitos e espessos pacotes de formação ferrífera bandada (Resende \& Jost, 1994, 1995a). A unidade passa gradualmente para a Formação Cabaçal, composta por espessos pacotes de metapelitos carbonosos, subdivididos em três membros. O membro inferior compreende metapelitos carbonosos com intercalações de metabasalto e lentes de gondito. O membro intermediário é um horizonte contínuo longitudinal no greenstone belt e que, no extremo sul, é composto por gondito que passa, a norte, para uma associação de gondito e barita maciça, com passagem gradual para formação ferrífera bandada e barita e, no extremo norte, para formação ferrífera bandada. No topo do horizonte ocorre metachert. $\mathrm{O}$ membro superior compreende apenas metapelitos carbonosos com raras lentes de metachert. Assim como no greenstone belt Crixás, os metapelitos carbonosos desta formação contém alguns intervalos com intercalações de metagrauvacas, as quais predominam no topo da sequência. Jost et al. (1995) designaram as metagrauvacas como Membro Superior da Formação Cabaçal e Jost et al. (2012) como Formação Mata Preta (Fig. vB)

No greenstone belt Pilar de Goiás, as unidades metassedimentares ocorrem em duas escamas tectônicas (Resende \& Jost, 1995b) (Fig. vC). A unidade inferior, denominada Formação Boqueirão e localizada tectonicamente acima dos metakomatiitos e metabasaltos, é formada por metarenitos finos calcíferos e lentes de metadolomito e é interpretada como um resíduo de margem continental passiva alóctone. A unidade superior, denominada Formação Serra do Moinho, está tectonicamente em contato sobre a Formação Boqueirão e é composta por metagrauvacas que apresentam semelhanças com as metagrauvacas dos greenstone belts Crixás e Guarinos, diferindo pela menor espessura das camadas e pela textura fina a muito fina. O tamanho médio da granulometria destas rochas cresce do greenstone belt Pilar de Goiás até os greenstone belts Guarinos e Crixás, sugerindo que o greenstone belt Crixás seria mais proximal da área-fonte (Jost et al., 2014).

No greenstone belt Faina, as seções metassedimentares representam dois ciclos plataformais completos, o primeiro reunido na Formação Fazenda Tanque e o segundo nas formações Serra de São José e Córrego do Tatú (Resende et al., 1998). A base das sequências em ambos os ciclos é composta por metaconglomerado, seguido de metarenitos, espessos pacotes de metapelitos e metadolomitos sobrepostos por formações ferríferas bandadas. O 
metaconglomerado basal do primeiro ciclo ocorre em raras lentes de metadiamictito com matriz rica em clorita, e com clastos de metabasalto, metakomatiito e quartzo leitoso. $\mathrm{O}$ metaconglomerado basal do segundo ciclo, denominado de Formação Arraial Dantas por Carvalho et al. (2013), é uma camada-guia longitudinalmente disposta ao longo do greenstone belt e que se estende por cerca de $40 \mathrm{~km}$, com $90 \mathrm{~m}$ de espessura média. Este compreende uma associação de metarenitos impuros, metapelitos e metaconglomerados em canais, ora suportados por matriz (diamictitos) e ora por clastos. Os clastos são irregulares, pouco arredondados, sem esfericidade, e compostos de metarenito, às vezes com pirita, quartzito, veio de quartzo, formação ferrífera bandada, gnaisses, granitos, xistos e raros turmalinitos. A natureza dos clastos indica que o metaconglomerado do primeiro ciclo foi alimentado com detritos de área-fonte máfico-ultramáfica, possivelmente as rochas metavulcânicas sotopostas, ao passo que os clastos do metaconglomerado do segundo ciclo indicam erosão de rochas do primeiro ciclo e áreas-fonte cratônicas, com rochas de variados graus metamórficos (Resende et al., 1998; Carvalho et al., 2013) (Fig. vD).

No greenstone belt Serra de Santa Rita, a sequência metassedimentar é agrupada na base pela Formação Fazenda Limeira, formada por metapelitos carbonosos os quais, para o topo, dão lugar a metachert, formações ferríferas bandadas e metadolomitos. Esta formação está sotoposta em discordância erosiva a metaturbiditos da Formação Fazenda Cruzeiro, interpretados como o extravasamento do segundo ciclo sedimentar do greenstone belt Faina, através da quebra continental em direção ao ambiente marinho mais profundo do greenstone belt Serra de Santa Rita (Resende et al., 1998) (Fig. vE)

Estudos de proveniência e modelamento da composição química das áreas-fonte das cargas detríticas dos greenstone belts Faina e Serra de Santa Rita realizados por Resende et al. (1999) indicam que os protólitos do primeiro ciclo sedimentar do greenstone belt Faina e os metapelitos carbonosos do greenstone belt Serra de Santa Rita foram alimentados por áreasfonte dominadas por rochas ultramáficas e máficas, subordinadamente félsicas. Em contraste, as cargas clásticas do segundo ciclo do greenstone belt Faina e os metarritmitos de topo do greenstone belt Serra de Santa Rita provieram de áreas-fonte dominadas por material granítico, o que implica em significativa mudança nas caraterísticas das áreas-fonte de um ciclo ao outro. 


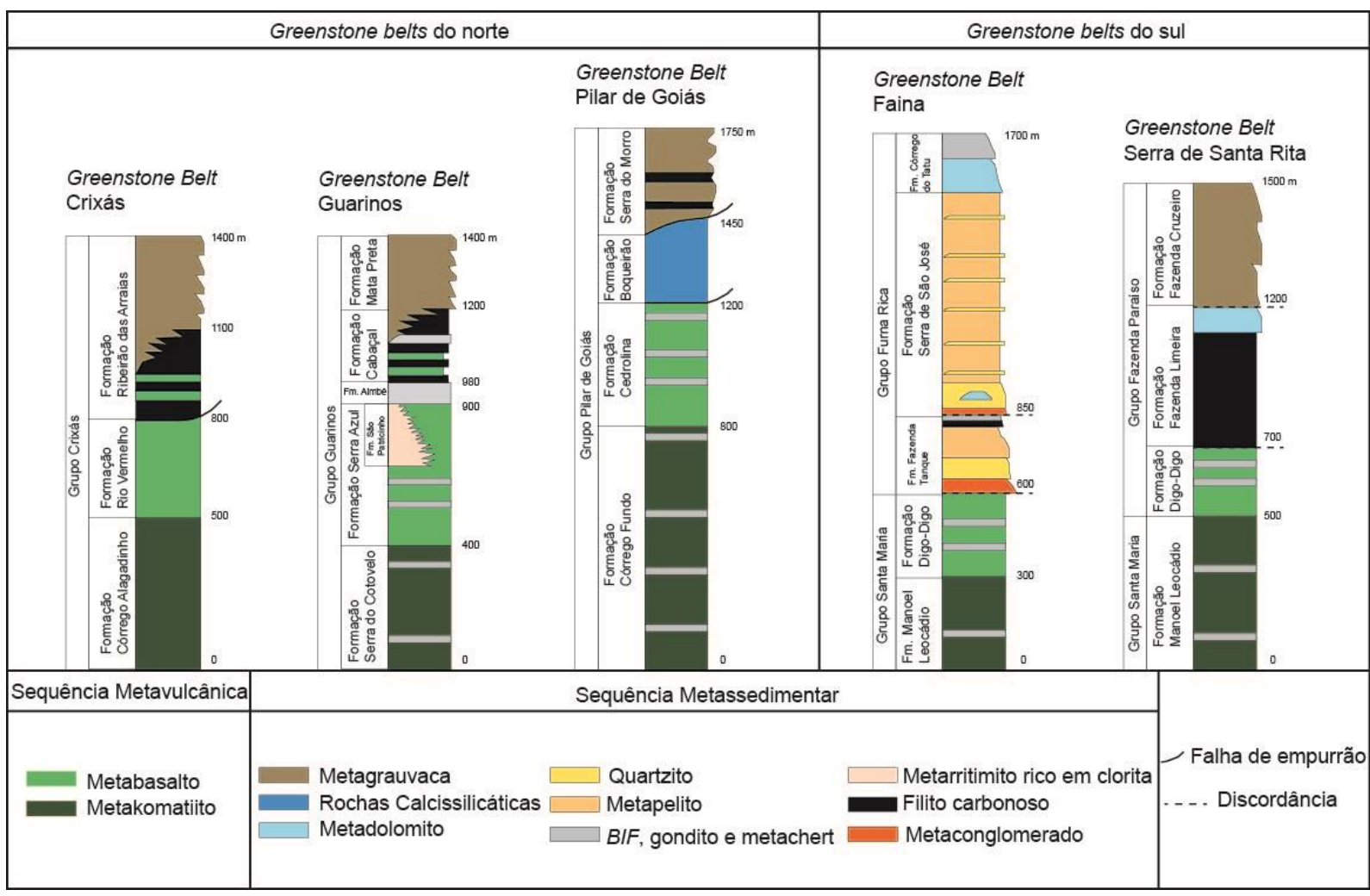

Fig. v. Colunas estratigráficas dos greenstone belts do Terreno Arqueano-Paleoproterozóico de Goias. Adaptado de Jost et al. (2014).

\subsubsection{Geocronologia e isótopos de carbono em metadolomitos}

As datações dos metakomatiitos e metabasaltos do greenstone belt Crixás foram obtidas a partir de idades isocrônicas $\mathrm{Sm}-\mathrm{Nd}$ de $2825 \pm 98 \mathrm{Ma}, \mathrm{Pb}-\mathrm{Pb}$ em rocha total de

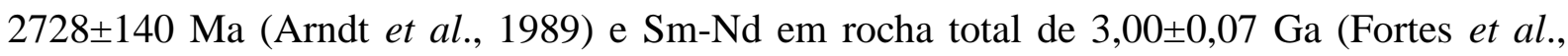
2003). Isto indica que as rochas metavulcânicas do greenstone belt Crixás são do Arqueano.

No greenstone belt Guarinos, uma amostra de metaturbidito com clastos de metabasalto pertencente à Formação São Patricinho revelou que os cristais detríticos mais jovens de zircão, texturalmente homogêneos como típico de rochas máficas, geraram a idade U-Pb concordante de $2180+36 /-30 \mathrm{Ma}$, indicando uma idade paleoproterozóica para a sequencia metassedimentar superior do greenstone belt Guarinos (Jost et al., 2012). As relações de contato lateral entre a Formação São Patricinho e os metabasaltos da Formação Serra Azul e a proveniência parcial da carga clástica a partir de rochas máficas, sugerem que os metabasaltos do greenstone belt Guarinos também sejam paleoproterozóicos. Os demais cristais de zircão apresentaram crescimento oscilatório típico de rochas félsicas e geraram idades de $2420 \pm 22$ a $2511 \pm 45$ Ma e de $2714 \pm 21$ a $2849 \pm 27$ Ma. A proveniência destes cristais 
detríticos de zircão pode ser justificada pelo espectro geocronológico dos ortognaisses e dos diques máficos adjacentes (Jost et al., 2014).

No greenstone belt Pilar de Goiás, uma amostra de metabasalto atribuído à Formação Cedrolina e coletada imediatamente abaixo da escama de empurrão com rochas calcissilicáticas da Formação Boqueirão continha uma única população de cristais de zircão

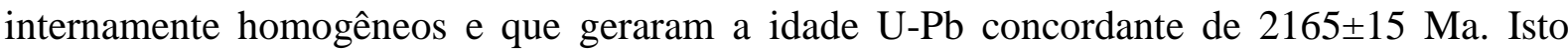
indica que parte da seção metavulcânica do greenstone belt Pilar de Goiás também é paleoproterozóica (Jost et al., 2014).

No greenstone belt Faina, Resende et al. (1999) obtiveram uma idade modelo Sm-Nd $\mathrm{T}_{\mathrm{DM}}$ de 3,0 Ga em amostra da matriz do metaconglomerado basal do primeiro ciclo sedimentar, rico em clastos de rochas máficas e ultramáficas, e para o metapelito carbonoso da base do pacote metassedimentar do greenstone belt Serra de Santa Rita, de proveniência clástica idêntica. Os autores interpretaram que esta idade modelo poderia refletir a idade das rochas metavulcânicas da base destes greenstone belts. Novos dados LA-ICP-MS U-Pb em zircão de uma amostra de anfibolito (metabasalto) do greenstone belt Serra de Santa Rita são apresentados neste trabalho e confirmam que as seções metavulcânicas destes greenstone belts são do Mesoarqueano ( 2,96 Ga).

Portanto, os dados isotópicos disponíveis indicam que as seções metavulcânicas dos greenstone belts Crixás, Faina e Serra de Santa Rita são arqueanas, ao passo que nos greenstone belts Guarinos e Pilar de Goiás as seções metavulcânicas são provavelmente paleoproterozóicas (riacianas).

Em relação às rochas metassedimentares, dados geocronológicos $\mathrm{Sm}-\mathrm{Nd}$ do topo da seção do greenstone belt Crixás mostraram que a área-fonte da carga detrítica tem idades entre 2,5 e 2,3 Ga (Fortes et al., 2003). A datação U-Pb em cristais de zircão detrítico em amostras de metagrauvacas do greenstone belt Crixás registraram idades no amplo intervalo de $3354 \pm 40 \mathrm{Ma}$ a $2209 \pm 28 \mathrm{Ma}$ (Tassinari et al., 2006; Jost et al., 2008). Tais dados mostram proveniência da carga clástica das rochas metassedimentares do greenstone belt Crixás a partir de áreas-fonte com rochas do Arqueano ao Paleoproterozóico (Riaciano).

No greenstone belt Guarinos a datação U-Pb em cristais de zircão detrítico em formação ferrífera bandada da Formação Aimbé revelou uma população de zircão com idade U-Pb de 2627 \pm 19 Ma e outra com idade de 2232 \pm 39 Ma (Jost et al., 2008). Em amostras de 
metagrauvacas da Formação Mata Preta foi relatada uma população dominante de zircão detrítico com idade U-Pb de 2176 \pm 11 Ma (Jost et al., 2012). No greenstone belt Pilar de Goiás, rochas calcissilicáticas da Formação Boqueirão revelaram idade isocrônica Sm-Nd de 2,2 Ga (Jost et al., 2008) e dados U-Pb em cristais de zircão detrítico de uma amostra de metagrauvaca da Formação Serra do Moinho revelaram que os cristais de zircão mais jovens possuem idade de $2178 \pm 19 \mathrm{Ma}$ (Jost et al., 2014).

Nos greenstone belts Faina e Serra de Santa Rita, as idades-modelo Sm-Nd das áreasfonte da carga detrítica dos pacotes metassedimentares inferiores varia entre 3,0 e 2,8 Ga, enquanto a dos pacotes superiores varia entre 2,7 e 2,6 Ga (Resende et al., 1999). Dados U-Pb em cristais de zircão detrítico em rochas metassedimentares do greenstone belt Faina apresentaram idades no amplo intervalo entre 3330 e 2815 Ma (Brant et al., 2015).

Portanto, se conclui que os protólitos sedimentares dos greenstone belts do Terreno Arqueano Paleoproterozóico de Goiás foram alimentados a partir do Riaciano, mas com forte contribuição de carga clástica do Arqueano. Tais idades impactam sobre a principal época metalogenética do terreno, pois a maioria dos depósitos minerais estão hospedados em rochas metassedimentares (Jost et al., 2014).

As assinatura isotópicas $\delta 13 \mathrm{C}$ em metadolomitos presentes como lentes em intervalos estratigráficos dos cinco greenstone belts foram investigadas por Fortes (1996) e Santos et al. (2008) nos greenstone belts da porção norte do terreno, e por Resende et al. (1998) e Jost et al. (2008) nos greenstone belts da porção sul. Os metadolomitos dos greenstone belts da porção norte e do topo do primeiro ciclo sedimentar dos greenstone belts da porção sul possuem valores de $\delta 13 \mathrm{C}$ muito positivos, variáveis de +10 a $+14 \%$. Estas assinaturas, combinadas com os dados isotópicos $\mathrm{U}-\mathrm{Pb}$, indicam que a deposição desses dolomitos ocorreu durante o evento Lomagundi (=Jatulian C-isotope anomaly). Este evento corresponde à primeira pronunciada anomalia de $\delta 13 \mathrm{C}$ em dolomitos terrestres, distribui-se mundialmente entre 2,22 e 2,06 Ga (Melezhik et al., 2007) e decorreu do declínio da glaciação Huroniana (Snowball Earth), com duração de 300 Ma (Kopp et al. 2005), entre o final do Sideriano e o início do Riaciano.

Os dados de $\delta 13 \mathrm{C}$ dos metadolomitos são compatíveis com a idade dos cristais detríticos de zircão mais jovens das rochas metassedimentares dos três greenstone belts do norte e das rochas calcissilicáticas do greenstone belt Pilar de Goiás, depositadas em equilíbrio com a água do mar. Já nos metadolomitos de topo do segundo ciclo sedimentar do 
greenstone belt de Faina os valores de $\delta 13 \mathrm{C}$ situam-se entre -0.66 e $+0.66 \%$, sugestivo de que a sua deposição ocorreu ao final da Anomalia Lomagundi, mas ainda durante o Riaciano, com provável extensão ao início do Orosiriano (Jost et al., 2014).

\subsection{Intrusões paleoproterozóicas e influências do Ciclo Brasiliano}

Após a cratonização do substrato no Arqueano, em torno de 2,7 Ga, o Terreno Arqueano-Paleoproterozóico de Goiás também apresenta o registro de atividade magmática do Paleoproterozóico representada por: (1) enxame de diques máficos nos complexos Caiçara e Anta com idades Sm-Nd de 2,3 a 2,5 Ga, correspondentes a uma fase de distensão crustal (Corrêa da Costa, 2003); (2) intrusão de enxame de diques máficos e de um diorito em lineamento transcorrente da porção sul do Complexo Hidrolina (Danni et al., 1986), de idade

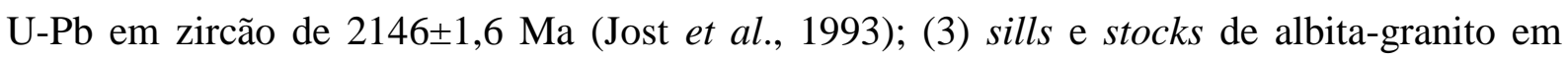
falhas de empurrão de vergência para o norte (Jost et al., 1992) em rochas metassedimentares dos greenstone belts da porção norte do terreno, com idade U-Pb em zircão de $2145 \pm 12 \mathrm{Ma}$ (Queiroz, 2000); (4) diques máficos que cortam a mineralização aurífera de Crixás, com zircão magmático de idade U-Pb de 2170 17 Ma (Jost et al., 2010). Estes dados sugerem que, após a cratonização arqueana, o terreno foi palco de um ciclo aparentemente completo de abertura durante o Sideriano, seguido por fechamento de orógeno no Riaciano. A esparsa distribuição regional destes eventos sugere que estes ocorreram em posição marginal a uma faixa móvel (Jost et al., 2014).

Entre o final do Riaciano e o Neoproterozóico, o Terreno Arqueano-Paleoproterozóico de Goiás aparentemente permaneceu-se estável. A sua amalgamação à Faixa Brasília durante o Ciclo Brasiliano resultou nos seguintes efeitos do Neoproterozóico registrados: (1) intrusões de muscovita-granito nos complexos Uvá e Caiçara e no greenstone belt Serra de Santa Rita

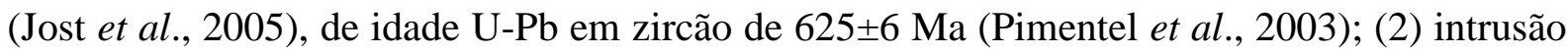
de um dique de albitito aurífero do extremo norte do greenstone belt Guarinos, com idade U$\mathrm{Pb}$ em zircão hidrotermal de $729 \pm 15 \mathrm{Ma}$ (Rodrigues, 2011); (3) anatexia parcial de ortognaisses do Complexo Moquém, sob a forma de finas bandas félsicas de idade U-Pb em

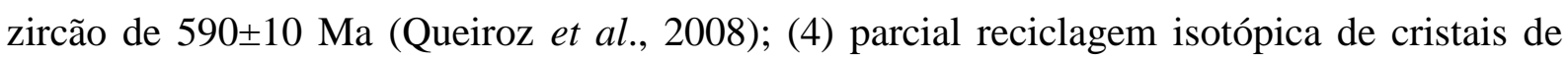
zircão magmáticos da maioria das amostras dos ortognaisses arqueanos, evidenciada por interceptos inferiores de idade U-Pb entre 750 e $590 \mathrm{Ma}$ (Queiroz et al., 2008) e reciclagem de cristais detríticos de rochas metassedimentares dos greenstone belts Crixás, Guarinos e Pilar de Goiás entre 500-450 Ma (Tassinari et al., 2006; Jost et al., 2008); (5) metamorfismo 
de paragêneses de zonas de alteração hidrotermal de depósito aurífero do greenstone belt Crixás, com idades K-Ar, Rb-Sr, Ar-Ar e Sm-Nd de 600 a 550 Ma (Fortes, 1996; Fortes et al., 2003). Estes dados indicam que a influência do Ciclo Brasiliano sobre as rochas da região foi restrita e coincide com a época da amalgamação do terreno na Faixa Brasília (Jost et al., 2014). 


\section{CAPÍTULO II - GEOCHEMISTRY AND ISOTOPIC SIGNATURES OF METAVOLCANIC AND}

METAPLUTONIC ROCKS OF THE FAINA AND SERRA DE SANTA RITA GREENSTONE BELTS,

CENTRAL BRAZIL: EVIDENCES FOR A MESOARCHEAN INTRAOCEANIC ARC 


\section{ABSTRACT}

The Archean-Paleoproterozoic Terrane of Goiás, located in Central Brazil, is an allochthonous part of the Neoproterozoic Tocatins Province and consists of an association of six Archean TTG complexes (orthogneisses and granites) and five gold-bearing ArcheanPaleoproterozoic greenstone belts. The Faina and Serra Santa Rita greenstone belts, located in the southern portion of the terrane, are investigated by geochemistry and isotope geology to establish the time of magmatism and tectonic environment. Our data show that the ultramafic rocks have some similar chemical characteristics to modern boninites, whereas the amphibolites are subdivided into two groups: the type 1 basalts group are tholeiites with flat REE patterns and are similar to back-arc basin basalts; the type 2 basalts group have high $\mathrm{Nb}$ contents and are comparable to $\mathrm{Nb}$-enriched basalts. Acid to intermediate rocks present some of the main chemical diagnostic features of adakites, in which the metandesites and metatonalites are comparable to high- $\mathrm{SiO}_{2}$ adakites, and the metadiorites, characterized by very high $\mathrm{MgO}, \mathrm{Cr}$ and $\mathrm{Ni}$ contents, are comparable to low- $\mathrm{SiO}_{2}$ adakites or high-Mg andesites. Metavolcanic and metaplutonic rocks show two main periods of magmatic crystallization ages with juvenile and slightly crustal contaminated rocks, respectively. The first occurred at 2.96-2.92 Ga with positive $\varepsilon N d(t)$ values of 2.16 to 2.77 , while the second formed at $2.79 \mathrm{Ga}$ with slightly negative $\varepsilon_{\mathrm{Nd}}(\mathrm{t})$ value of -0.30 . The volcanic and plutonic protholiths of the both greenstone belts were formed in an intraoceanic forearc-arc-back-arc system. The initial stage corresponds to ultramafic lava eruption in the forearc region of a proto-island arc, at $2.96 \mathrm{Ga}$. The evolution of the island arc and subduction progression led to oceanic slab-melting and generation of adakites. At $2.92 \mathrm{Ga}$, the adakitic melt was totally consumed by peridotite mantle and the subsequent melting of these hybridized mantle wedge generated high- $\mathrm{Mg}$ andesites that lodged in the crust as dioritic intrusions with high $\mathrm{MgO}, \mathrm{Cr}$ and $\mathrm{Ni}$ contents. The late stage corresponds to a continental arc formation at $2.79 \mathrm{Ga}$, marked by tonalitic magmatism and amalgamation with other island arcs and continental arcs of the TTG complexes of the Archean-Paleoproterozoic Terrane of Goiás.

Keymords: Tocantins Province, Goiás Massif, Archean-Paleoproterozoic Terrane of Goás, Faina greenstone belt, Serra de Santa Rita greenstone belt, Nb-enriched basalts, Adakites. 


\section{Introduction}

Archean greenstone belts are components of several cratons and present a wide variety of igneous and sedimentary rocks that carry the imprint of different tectonic environments, magmatic episodes and stages of metamorphism, deformation, metasomatism and mineralization (Anhaeusser, 2014; Pearce, 2014). The geochemical studies on metavolcanic rocks of greenstone belts have revealed two main types of associations: (1) a plume-related association composed of komatiites and tholeiitic basalts at oceanic and continental plateaus (e.g. Campbell et al., 1989; Herzberg, 1992; Xie et al., 1993; Arndt, 1994; Dostal and Mueller, 1997, 2004; Puchtel et al., 1998; Polat, 2009); and (2) a subduction-related association composed of calc-alkaline basalts, andesites, dacites and rhyolites, with minor occurrences of boninites, picrites, adakites, high- $\mathrm{Mg}$ andesites and $\mathrm{Nb}$-enriched basalts. (e.g. Kerrich et al., 1998; Hollings and Kerrich, 2000; Wyman et al., 2000, Polat and Kerrich, 2004; Hollings, 2002; Percival et al., 2003; Polat and Hofmann, 2003; Shchipansky et al., 2004; Polat and Kerrich, 2006; Ujike et al., 2007; Manikyamba et al., 2009; Khanna et al., 2015).

The Archean-Paleoproterozoic Terrane of Goiás, located in Central Brazil, is an allochthonous part of the Tocantins Province, a large Brasiliano/Pan-African orogen of the South American Platform formed during the Neoproterozoic Brasiliano orogeny. The terrane amalgamated to the province during the late stages of the orogeny and consists of an association of six Archean TTG complexes (tonalite-trondhjemite-granodiorite orthogneisses) and five Archean to Paleoproterozoic (Rhyacian) greenstone belts (Jost et al., 2013). The greenstone belts comprise lower units of metakomatiites overlain by metabasalts and upper units of metasedimentary rocks and host diverse types of gold deposits (Jost et al. 2014). The available data regarding the region are currently not sufficient for a detailed reconstruction of the magmatism and the different periods of crustal accretion, and to outline the tectonic environment in which the different units were formed.

The main purpose of this study is to provide an interpretation of the tectonic setting of the Faina and Serra de Santa Rita greenstone belts, located in the southern portion of the Archean-Paleoproterozoic Terrane of Goiás, based on new geochemical and isotopic data of metavolcanic and metaplutonic rocks. We suggest that these rocks constitute an association generated in subduction settings, which include adakite-like rocks, high-Mg andesites and $\mathrm{Nb}$ enriched basalts occurrences. We intent to contribute to the different juvenile crustal accretion 
characterization, which preceded the formation of the Archean orogenic systems, and to comprehend the mechanism of crustal growth involved in the formation of the southern portion of the Archean-Paleoproterozoic Terrane of Goiás.

\section{Geological setting}

The Tocantins Province (Almeida et al., 1981) represents a large Brasiliano/PanAfrican orogen of the South American Platform formed by the collision of the Amazonian, São Francisco-Congo and Paranapanema cratons, the later is current covered by Cenozoic rocks of the Paraná Basin, that led to the amalgamation of the supercontinent Western Gondwana in the Neoproterozoic. The province consists of three fold belts: the Paraguai Belt, on the southwestern portion, the Araguaia Belt, on the northern portion, and the Brasilia Belt, that borders the western edge of the São Francisco Craton (Pimentel et al., 2000).

The Brasilia Belt, located in Central Brasil (Fig. 1), is divided into a NE-SW northern branch and a NW-SE southern branch. The separation of these two branches is established by the Pirineus Syntaxis that marks the change of the structural directions and configures the superimposition of the northern structures onto the southern counterparts (Araújo Filho, 2000). Both branches are divided into the External and Internal Zones (Fig. 1). The External Zone includes thick sequences of low-grade metasedimentary rocks and their basements structured in fold-and-thrust belts verging towards the São Francisco Craton. The Internal Zone comprises: (1) the metamorphic core of the orogen, known as Anápolis-Itauçu Granulitic Complex (Piuzana et al., 2003) and Uruaçu Complex (DellaGiustina et al., 2009), distal metasedimentary rocks of the Araxá Group (Seer et al., 2001) and ophiolitic fragments (Strieder \& Nilson, 1992); (2) the Goiás Massif, composed mainly of allochtonous cratonic fragments that constitute the Archean-Paleoproterozoic Terrane of Goiás (Jost et al., 2013), a Paleoproterozoic metasedimentary cover and Meso- to Neoproterozoic mafic-ultramafic layered complexes associated with metavolcanosedimentary sequences (Ferreira Filho et al., 1992; Ferreira-Filho et al., 1994; Moraes et al., 2000); and (3) the Neoproterozoic Goiás Magmatic Arc, composed of metavolcanosedimentary sequences and orthogneisses disposed on a broad area of juvenile and continental crust generated during plate convergence between 990 and 630 Ma (Pimentel et al., 1991, 1997; Pimentel and Fuck, 1992; Pimentel et al., 2000, 2004; Junges et al., 2002, 2003; Laux et al., 2005) (Fig.1). 


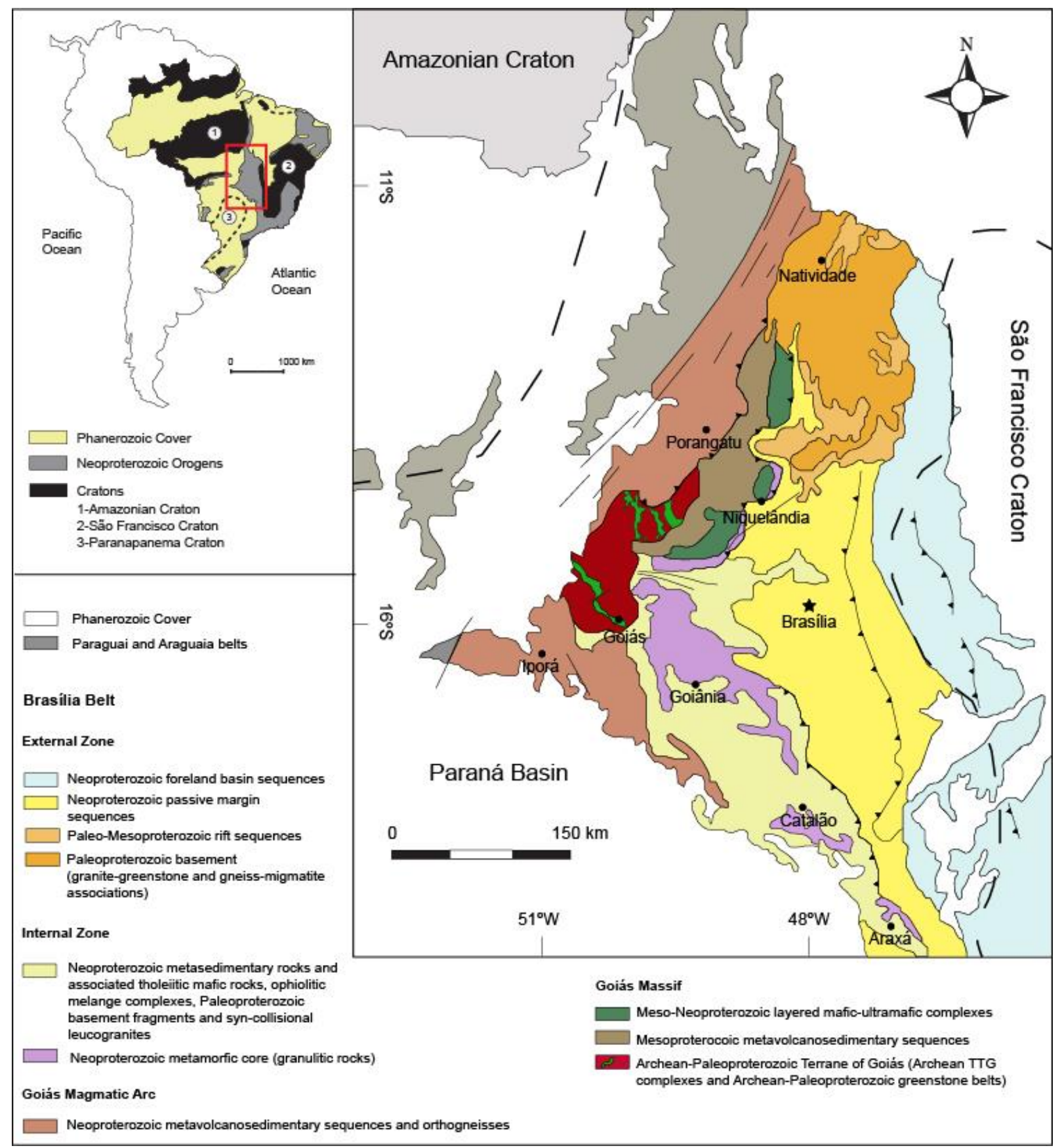

Fig. 1. Location of the Brasilia Belt and its main components. The Archean-Paleoproterozoic Terrane of Goiás is located in the midwestern portion of the belt (Modified after Pimentel et al., 2004).

\subsection{The Archean-Paleoproterozoic Terrane of Goiás}

The Archean-Paleoproterozoic Terrane of Goiás is located in the midwestern portion of the Brasilia Belt (Fig. 2A) and is composed of an association of six Archean TTG complexes (orthogneisses) and five Archean to Paleoproterozoic greenstone belts. The cratonization of the Archean substrate occurred at around $2.7 \mathrm{Ga}$ and the region was also subject to Paleoproterozoic magmatic activity related to crustal distension in the Siderian and 
closing of the orogen in the Rhyacian (Danni et al., 1986; Jost et al., 1992, 1993, 2010, 2014; Queiroz, 2000; Corrêa da Costa, 2003). The amalgamation of the Archean-Paleoproterozoic Terrane of Goiás to the Brasilia Belt during the Brasiliano orogeny in the Neoproterozoic resulted in granitic intrusions, partial anatexis of Archean orthogneisses and hydrothermal alteration broadly distributed (Fortes et al., 1996, 2003; Pimentel et al., 2003; Jost et al., 2005, 2008, 2014; Tassinari et al., 2006; Queiroz et al., 2008; Rodrigues, 2011).

\subsubsection{The TTG complexes}

The TTG complexes comprise tonalitic to granodioritic and minor granitic orthogneisses that differ in the structural framework, lithology associations and magmatic crystallization ages. In the northern portion of the terrane, are located the Anta, Caiamar, Moquém and Hidrolina complexes, and in the southern portion, the Caiçara and Uvá complexes (Fig. 2B). Two stages of magmatism were recognized in the northern complexes. The first stage corresponds to juvenile poly-deformed tonalitic, granodioritic and granitic orthogneisses of the Hidrolina and Caiamar complexes and part of the Anta Complex, with U$\mathrm{Pb}$ zircon crystallization ages between 2845 and $2785 \mathrm{Ma}$ and initial $\varepsilon \mathrm{Nd}$ values of -1.0 to +2.41. Inherited zircon crystals of 3.3 to $3.15 \mathrm{Ga}$ and Sm-Nd model age of $3.0 \mathrm{Ga}$ indicate that these magmas were contaminated by older sialic crust (Queiroz et al., 2008). The second stage, restricted to the Moquém Complex and part of the Anta Complex, corresponds to sheetlike granitic to granodioritic intrusions of crustal derivation with $\mathrm{U}-\mathrm{Pb}$ zircon crystallization ages between 2792 and $2707 \mathrm{Ma}$ and initial $\varepsilon_{\mathrm{Nd}}$ value of -2.2 (Queiroz et al., 2008).

The Caiçara Complex, located in the southern portion of the terrane, is composed predominantly of tonalitic orthogneisses with $\mathrm{U}-\mathrm{Pb}$ zircon crystallization age of $3.14 \mathrm{Ga}$ and minimum Sm-Nd model age of 3.1 Ga (Beghelli Junior, 2012). The tonalitic orthogneisses are intruded by smaller granodiorites, granites and charnorckites plutons with $\mathrm{U}-\mathrm{Pb}$ crystallization ages of 2.8 Ga and Sm-Nd model ages of 2.9 Ga (Beghelli Junior, 2012). The Uvá Complex is located in the southernmost portion of the terrane and is constituted of two orthogneisses groups (Jost et al., 2005, 2013). The dominant group is the oldest and comprehends polydeformed tonalitic to granodioritic orthogneisses and a diorite stock. The tonalitic orthogneisses present U-Pb zircon crystallization ages between 3040 and 2930 Ma (Jost et al., 2013 ) and the diorite stock presents U-Pb zircon crystallization age of $2934 \pm 5 \mathrm{Ma}$ (Pimentel et al., 2003). The second group corresponds to sheet-like tonalite and monzogranite intrusions with U-Pb zircon crystallization age of 2846 and $2764 \mathrm{Ma}$ (Jost et al., 2005, 2013). Therefore, 
the Archean substrate of the region is polycyclic and the TTG complexes of the southern portion of the Archean-Paleoproterozoic Terrane of Goiás are older than the northern counterparts.

\subsubsection{The greenstone belts}

The greenstone belts occur as five elongated and irregularly shaped sequences situated between the TTG complexes. It the northern portion, are located the Crixás, Guarinos and Pilar de Goiás greenstone belts, and in the southern portion, the Faina and Serra de Santa Rita greenstone belts (Fig. 2B). Their contacts with the adjacent TTG rocks are tectonic and marked by northwest-verging thrust faults (Jost et al., 2005, 2013). The stratigraphy of the greenstone belts comprises lower metavolcanic sequences of metakomatiites overlain by metabasalts and upper metasedimentary sequences. The rocks underwent a greenschist to amphibolite facies metamorphism and the stratigraphic reconstruction is complex due to the fragmentary state, polycyclic deformation, thinning, thickening and the rarity of marker horizons, which hinders the correlation through the structural and igneous discontinuities (Jost et al., 2014).

Primary volcanic features are locally preserved and include pillow lavas, spinifex and cumulate textures, polyhedral disjunctions, flux breccia and vesicles (Danni et al., 1981; Teixeira, 1981; Teixeira et al., 1981; Kuyumjian \& Teixeira, 1982; Danni et al., 1986; Profumo, 1993; Jost et al., 1995). Intercalation of banded iron formation, gondite and metachert can occur in different proportions among the metavolcanic rocks. The crystallization ages of the volcanic protoliths of the five greenstone belts range from Archean to Paleoproterozoic. The metakomatiites of the Crixás greenstone belt presented $\mathrm{Sm}-\mathrm{Nd}$ isochronic age of 3.00 $\pm 0.07 \mathrm{Ga}$ (Fortes et al., 2003). On the other hand, U-Pb zircon data for the Guarinos and Pilar de Goiás greenstone belts indicate that the metabasalts are from the Rhyacian, with ages at around $2.1 \mathrm{Ga}$ (Jost et al., 2012; Jost et al., 2014). New LA-ICP-MS $\mathrm{U}-\mathrm{Pb}$ zircon data for the Faina and Serra de Santa Rita greenstone belts are presented here and indicate a Mesoarchean age for their metavolcanic sequences (2.96 Ga).

The metasedimentary sequences of the greenstone belts are markedly constrasting (Jost \& Oliveira, 1991; Resende \& Jost, 1994, 1995a, 1995b; Jost et al., 1995, 2012; Resende et al., 1998). Several isotopic data have shown provenance of the clastic load from the Archean to the Paleoproterozoic (Rhyacian) (Resende et al., 1999; Fortes et al., 2003; Tassinari et al., 2006; Jost et al., 2008; Jost et al., 2012; Jost et al., 2014; Brant et al., 2015). 
Isotopic data of metadolomites of the northern greenstone belts and of the first sedimentary cycle of the southern greenstone belts revealed highly positive $\delta 13 \mathrm{C}$ values, variable from +10 to +14\%o (Fortes, 1996; Resende et al., 1998; Jost et al., 2008; Santos et al., 2008). These values are comparable to the first $\delta 13 \mathrm{C}$ positive anomaly in Earth's dolomites that is worldwide distributed between 2.2 and $2.06 \mathrm{Ga}$, known as Lomagundi-Jatuli positive $\delta 13 \mathrm{C}$ excursion (Melezhik et al., 2007). These data suggest that the deposition of the dolomites of these greenstone belts occurred due to the Huronian glaciation (Snowball Earth) decay, between the end of the Siderian and the beginning of the Rhyacian (Jost et al., 2014). In the Faina greenstone belt, the $\delta 13 \mathrm{C}$ values in metadolomites of the second sedimentary cycle fell between -0.66 and $+0.66 \%$, suggesting that the deposition occurred at the end of the Lomagundi-Jatuli anomaly, but still during the Rhyacian, with likely extension into the early Orosirian (Resende et al., 1999; Jost et al., 2014).

In summary, the available isotopic data indicate that the metasedimentary rocks of the five greenstone belts of the Archean-Paleoproterozoic Terrane of Goiás and the metavolcanic rocks of the Guarinos and Pilar de Goiás greenstone belts have Paleoproterozoic (Rhyacian) ages, whereas the metavolcanic rocks of the Crixás, Faina and Serra de Santa Rita greenstone belts have Mesoarchean ages.

\subsubsection{The Faina and Serra de Santa Rita greenstone belts}

The Faina and Serra de Santa Rita greenstone belts, located in the southern portion of the Archean-Paleoproterozoic Terrane of Goiás, are disposed in a NW-SE synform and are separated by the Faina Fault (Fig. 2C). These greenstone belts are located between the Caiçara and Uvá complexes and their contacts are tectonic and marked by high-angle northeastverging shear zones that completely obliterate their original architecture (Resende et al., 1998; Jost et al., 2005).

The Faina and Serra de Santa Rita greenstone belts comprise lower metavolcanic sequences unconformably overlain by metasedimentary rocks. The metavolcanic rocks are more abundant in the Serra de Santa Rita greenstone belt and in the northern portion of the Faina greenstone belt and have predominantly ultramafic composition (Fig. 2C). The mafic metavolcanic rocks correspond to amphibolites restricted to the Serra de Santa Rita greenstone belt and are associated with lenses of metandesites and metavolcanoclastic rocks. Dioritic to tonalitic poly-deformed intrusions also occur among these rocks. The metavolcanic 
sequences were affected by at least two greenschist to amphibolite facies metamorphic events. The overlying metasedimentary sequences register only the greenschist facies metamorphism.

The metasedimentary sequences of the Faina and Serra de Santa Rita greenstone belts differ from each other in several aspects and were probably developed under different conditions and sedimentary environments. Two metasedimentary sequences separated by a thrust fault occur in the Faina greenstone belt (metasedimentary sequences 1 and 2) (Fig. 2C). These two sequences represent two transgressive cycles of increasing depth (Resende et al., 1998). The base of both sequences is composed of metaconglomerates, followed by metarenites, thick packages of metapelites and metadolomites overlain by banded iron formations. The basal metaconglomerate of the first sedimentary cycle is in contact with the lower metavolcanic unit by an erosive unconformity and occurs as metadiamictite lenses with clasts of metabasalt, metakomatiite and milky quartz. This conglomerate protolith was fed with clasts from a mafic-ultramafic source area, possibly the underlying metavolcanic rocks (Resende et al., 1998). The basal metaconglomerate of the second cycle is associated with impure metarenites and metapelites. The nature of the clasts indicates that this conglomerate protolith was formed by the erosion of rocks from the first sedimentary cycle and cratonic source areas (Resende et al., 1998; Carvalho et al., 2013).

The sedimentation in the Serra de Santa Rita greenstone belt occurred in a deep marine environment progressing to a shallow water. The metasedimentary sequence is composed of lower carbonaceous schists overlain by metachert, banded iron formation and metadolomites. These rocks are overlain by metaturbidites that are interpreted as an "extravasation" of the second sedimentary cycle of the Faina greenstone belt through a continental break towards the deeper marine environment of the Serra de Santa Rita greenstone belt (Resende et al., 1998). 


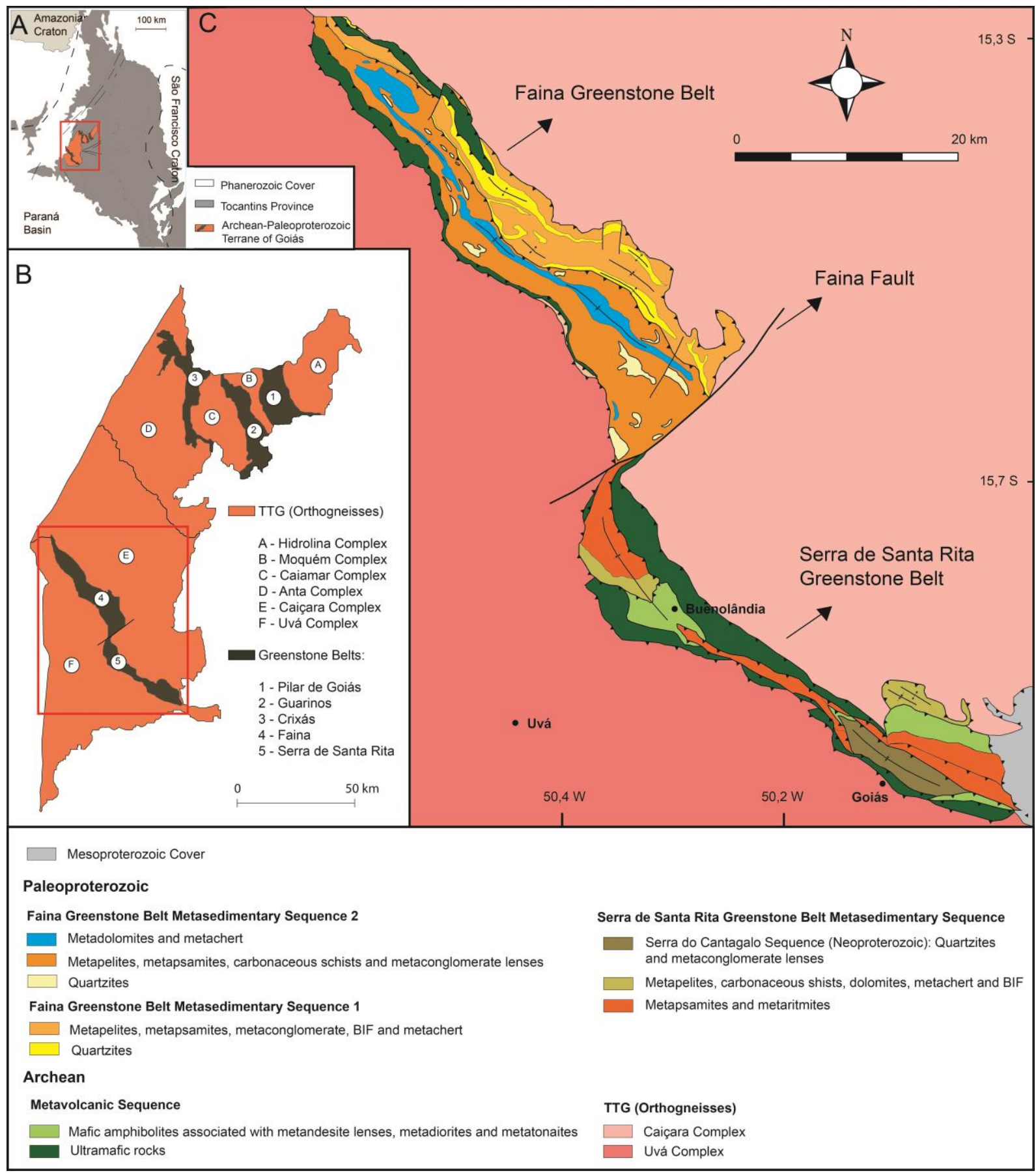

Fig. 2. The Archean Paleoproterozoic Terrane of Goiás and the Faina and Serra de Santa Rita greenstone belts, located in the southern portion of the terrane. (A) Location of the Archean-Paleoproterozoic Terrane of Goiás in the Brasilia Belt. (B) Distribution of the TTG complexes and greenstone belts that constitute the ArcheanPaleoproterozoic Terrane of Goiás; the Faina and Serra de Santa Rita greenstone belts are highlighted. (C) Geological map of the Faina and Serra de Santa Rita greenstone belts (Modified after Baeta et al., 2000 and Toledo et al., 2014). 


\section{Sampling and analytical methods}

\subsection{Sampling}

The studied samples were collected during two field works of geological mapping of the Faina greenstone belt and part of the Serra de Santa Rita greenstone belt on a 1:25.000 scale. The samples of ultramafic rocks were collected from outcrops along the Faina and Serra de Santa Rita greenstone belts. The samples of amphibolites, metandesites, metadiorites and metatonalites were collected from outcrops in specific areas of the Serra de Santa Rita greenstone belt. In addition to the rocks collected from outcrops, this study includes data of four metandesite samples from drilling cores located in the southern portion of the Serra de Santa Rita greenstone belt. The most representative and preserved samples were selected for petrographic, geochemical and isotopic studies. The location and coordinates of the samples are listed in Table 1 (Appendix).

\subsection{Electron microprobe analysis}

Mineral chemical analyses were conducted in order to support the petrographic characterization of metavolcanic and metaplutonic rocks of the Faina and Serra de Santa Rita greenstone belts. The analyses were performed at the Electron Microprobe Laboratory of the University of Brasilia (UnB), with a JEOL JXA-8230 equipment operating at $20 \mathrm{kv}$ and 20 $\mathrm{nA}$. The minerals analyzed include amphiboles, chlorite, plagioclase and oxides. The data are listed in tables 2.1-2.3 (Appendix).

\subsection{Whole-rock geochemistry}

The samples selected for whole rock geochemical analyses were pulverized and analyzed at the ALS Geochemistry laboratory in Goiânia, Brazil, following standard laboratory procedures. Major elements were determined by X-Ray Fluorescence (XRF) and are presented in weight oxides percentages. The rare earth elements (REE), high field strength elements (HFSE) and large ion lithophile elements (LILE) were determined by ICP-MS and the metals $\mathrm{Ag}, \mathrm{As}, \mathrm{Cd}, \mathrm{Co}, \mathrm{Cu}, \mathrm{Li}, \mathrm{Mo}, \mathrm{Ni}, \mathrm{Pb}, \mathrm{Sc}, \mathrm{Tl}$ and $\mathrm{Zn}$ were determined by ICP-AES. Major element analyses were recalculated to $100 \mathrm{wt} . \%$ anhydrous basis for inter-comparisons. Chondrite and primitive mantle compositions, used for normalizations, and the N-MORB composition are those of Sun and McDonough (1989). Europium (Eu/Eu*) and cerium $\left(\mathrm{Ce} / \mathrm{Ce}^{*}\right)$ anomalies were calculated with respect to the neighboring elements on chondritenormalized REE diagrams, following method of Taylor and McLennan (1985). Mg-numbers 
(\#Mg) were calculated as the molecular ratios of $\mathrm{Mg} /\left(\mathrm{Mg}+\mathrm{Fe}^{2+}\right) \times 100$. Major and trace elements data are listed in Table 3 (Appendix).

\subsection{U-Pb geochronology}

The initial preparation of five selected samples for U-Pb zircon dating was conducted at the Geochronology Laboratory of the University of Brasilia (UnB) by traditional methods of crushing, milling and sieving. The concentration of non-magnetic grains was conducted using a Frantz isodynamic magnetic separator. The individual zircon crystals were manually separated from the non-magnetic concentrate under a binocular microscope. All zircon grains were mounted in epoxy mounts and polished until they were revealed. Images of zircon were obtained using optical, cathodluminescence and back-scatter electron microscopes. The zircon crystals were dated by the LA-MC-ICP-MS method at the Geochronology Laboratory of the University of Brasilia (UnB) and with the LA-SF-ICP-MS method at the Geochronology Laboratory of the Federal University of Ouro Preto (UFOP). Sample TF14-XI-016 (chloritite) was dated using a laser ablation system (New Wave UP213) coupled to a MC-ICP-MS (Neptune) at the UnB. Isotope data were acquired using static mode with spot size of $30 \mu \mathrm{m}$. Samples TF14-I-099 (chloritite), TF14-XII-178 (amphibolite), PFG-CA-04A (metadiorite) and TF14-XI-183 (metatonalite) were dated by the SF-LA-ICP-MS method using a ThermoFinnigan Element 2 sector field ICP-MS coupled to a CETAC213 ultraviolet laser system at the UFOP. Laser spot size of $20 \mu \mathrm{m}$ was used and data were acquired in peak jumping mode during $20 \mathrm{~s}$ background measurement followed by $20 \mathrm{~s}$ sample ablation.

For both laboratories, raw data were corrected for background signal, and laserinduced elemental fractional and instrumental mass discrimination were corrected by the reference zircon (GJ-1) (Jackson et al., 2004). The common Pb correction was based on the $\mathrm{Pb}$ composition model (Stacey \& Kramers 1975). To evaluate the accuracy and precision of

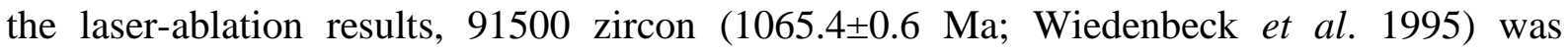
analyzed at the UnB laboratory, while at the UFOP laboratory, the Plešovice zircon $(337 \pm 1$

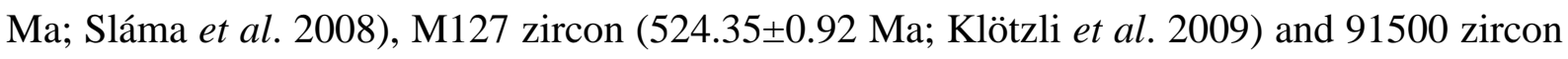
were analyzed. The external error is calculated after propagation error of the GJ-1 mean and the individual zircon sample (or spot). Buhn et al. (2009) and Santos (2015) described the detailed analytical methods and data treatment. The age calculation was carried out using Isoplot-Ex (Ludwig, 2003). The LA-MC-ICP-MS and LA-SF-ICP-MS U-Pb isotopic analytical data are listed in tables 4.1-4.5 (Appendix). 


\subsection{Sm-Nd isotopes}

The five selected samples for whole-rock $\mathrm{Sm}-\mathrm{Nd}$ isotopic analyses were pulverized using an agate mill and analyzed at the Geochronology Laboratory of the University of Brasilia (UnB). Whole-rock powders ( 100 mg of sample powder) were spiked with a combined ${ }^{150} \mathrm{Nd}^{-149} \mathrm{Sm}$ tracer and dissolved using a solution of 5:1 $\mathrm{HF}^{-\mathrm{HNO}_{3}}$ in Savillex® tvials on a hot plate. After cooling and evaporation of the $\mathrm{HF}-\mathrm{HNO}_{3}$ solution, samples were re-dissolved in the Savillex ${ }^{\circledR}$ vials with $7 \mathrm{ml}$ of $6 \mathrm{~N} \mathrm{HCl}$, evaporated, and then taken up in $3 \mathrm{ml}$ of $2.5 \mathrm{~N} \mathrm{HCl}$. The chemical extraction of $\mathrm{Sm}$ and $\mathrm{Nd}$ follows the conventional chromatographic procedure described by Gioia \& Pimentel (2000). Each sample was dried out to a solid and then loaded with $0.25 \mathrm{~N} \mathrm{H}_{3} \mathrm{PO}_{4}$ on appropriated filament (Ta for Sm and $\mathrm{Re}$ for Nd). All samples were analysed using a Thermo Scientific TRITONTM Plus Thermal Ionization Mass Spectrometer (TIMS) operating in the static multi-collector mode at the UnB. $100-120$ ratios were collected with a 0.5 to 1 -volt ${ }^{144} \mathrm{Nd}$ beam. $\mathrm{Nd}$ ratios were normalized to ${ }^{146} \mathrm{Nd} /{ }^{144} \mathrm{Nd}=0.7219$. All analyses were adjusted for variations in instrumental bias due to periodic adjustment of collector positions as monitored by measurements of our internal standards. Repeated measurements on the USGS BHVO-1 standard gave ${ }^{143} \mathrm{Nd} /{ }^{144} \mathrm{Nd}=0.512996 \pm 0.000006(2 \mathrm{SD} ; \mathrm{n}=7)$ during the course of this study. Average blank values were $<100 \mathrm{pg}$ for $\mathrm{Sr}$ and $\mathrm{Sm}$, and $<500 \mathrm{pg}$ for $\mathrm{Nd}$. Correction for blank was insignificant for $\mathrm{Nd}$ isotopic compositions and generally insignificant for $\mathrm{Sm} / \mathrm{Nd}$ ratios. Neodymium crustal residence (or depleted mantle) model ages $\left(\mathrm{T}_{\mathrm{DM}}\right.$ ) were calculated following the depleted mantle model of De Paolo (1981). Sm-Nd isotopic data are listed in Table 5 (Appendix).

\section{Field aspects and petrography}

\subsection{Ultramafic rocks and chloritites}

The metavolcanic rocks of ultramafic composition are the most abundant in the Faina and Serra de Santa Rita greenstone belts. These rocks are predominantly ultramafic schists and fine- to medium-grained massive rocks. Primary igneous features are locally preserved and comprise pillow lavas and cumulate-textured zones. The pillow lavas occur in massive fine-grained rocks in the southern portion of the Serra de Santa Rita greenstone belt and attest the subaqueous volcanic character of these ultramafic rocks (Fig. 3A). The ultramafic schists are composed of variable quantities of chlorite, talc and tremolite, which mark the tectonic foliation of these rocks. Magnetite, chromite and apatite occur as accessory minerals. Syn- to 
post-tectonic euhedral tremolite porphyroblasts and post-tectonic magnetite porphyroblasts are common (Fig. 4A).

The rocks with preserved cumulate textures are massive and characterized by pseudomorphs of cumulus olivine totally replaced by serpentine. The olivine pseudomorphs are encompassed by tremolite, $\mathrm{Mg}$-hornblende and talc that substituted the original igneous intercumulus minerals, characterizing mesocumulate and orthocumulate reliquiar textures (Fig. 4B). Similar cumulate textures are recognized at the base of thick komatiite lava flows of several worldwide greenstone belts (Arndt, 2008). However, the texture variations observed in the classical layered komatiite flow occurrences, such as spinifex-textured horizons, were not recognized in ultramafic rocks of the Faina and Serra de Santa Rita greenstone belts.

Some centimeter- to meter-thick irregular chloritite layers are interleaved with ultramafic schists and cumulate-textured rocks. The chloritites are composed mainly of $\mathrm{Mg}$ chlorite $(>95 \%)$ in a diablastic texture or rarely oriented according to the tectonic foliation. Apatite, magnetite and zircon are accessory minerals in these rocks. The chloritites' chemical characteristics will be discussed later, which permit to distinguish them from the other ultramafic rocks; they are not interpreted here as metavolcanic rocks, unlike the ultramafic schists and cumulate-textured rocks of the Faina and Serra de Santa Rita greenstone belts.

\subsection{Amphibolites}

The mafic metavolcanic rocks are restricted to the Serra de Santa Rita greenstone belt and are represented by fine- to medium-grained amphibolites (Fig. 3B). These rocks are composed mainly of Mg-hornblende and plagioclase (albite), with subordinate epidote, actinolite, chlorite and biotite. Magnetite, titanite and apatite are accessory minerals. Tectonic foliation is well marked by the preferential orientation of amphiboles and chlorite. The igneous texture is rarely preserved; it is characterized by subhedral plagioclase phenocrysts composing reliquiar porphyritic texture and minor intergranular texture domains. The mineral assemblage of these rocks, formed by hornblende + plagioclase (albite) \pm epidote, indicates that the metamorphic peak reached amphibolite facies. Nonetheless, retrometamorphic processes under greenschist facies are evidenced by the presence of chlorite, actinolite and biotite, which substitute in several degrees the hornblende crystals, predominately at the edges (Figs. 4C and 4D). The plagioclase is totally or partially replaced by epidote and has a sodic composition $\left(\mathrm{An}_{1-3}\right)$. The albitic composition of the plagioclase must be related to 
retrometamorphic processes under greenschist facies, but can also be result of late hydrothermal alteration processes.

\subsection{Metandesites}

Metandesite lenses occur among the amphibolites in the southern portion of the Serra de Santa Rita greenstone belt. The metandesites are interlayered with metavolcaniclastic rocks, metapelites, carbonaceous schists and metacherts with sulfide dissemination (Figs. 3C and 3D). Normally, the metamorphism and deformation obliterate the primary structures making it difficult to recognize the protoliths of these rocks. In the less deformed regions, the metandesites present preserved igneous texture and consist of euhedral to subhedral plagioclase (albite) phenocrysts embedded in a fine-grained groundmass of quartz, plagioclase (albite), muscovite and biotite (Fig. 4E). The plagioclase is partially replaced by epidote and the biotite is partially or fully substituted by chlorite. The strongly albitic composition of the plagioclase $\left(\mathrm{An}_{0.1-0.4}\right)$ may reflect the superimposed greenschist facies retrometamorphism and hydrothermal alteration. In the most deformed rocks, the original porphyritic texture is obliterated; the plagioclase phenocrysts are less preserved and highly saussuritized and the biotite is fully replaced by chlorite. Carbonate-rich venules oriented according to the foliation of the rocks are common.

\subsection{Metadiorites and metatonalites}

Dioritic intrusions also metamorphosed under amphibolite facies occur among the amphibolites of the Serra de Santa Rita greenstone belt. At the edge of these intrusions are found angular enclaves of fine-grained amphibolites that are possibly xenoliths of the greenstone belt's metavolcanic rocks (Figs. 3E and 3F). Mafic microgranular xenoliths are locally observed which may represent mingling features. The metadiorites are medium- to coarse-grained rocks composed of $\mathrm{Mg}$-hornblende, plagioclase (albite) and quartz. Titanite, magnetite and zircon are accessory minerals. Hornblende may be partially substituted by actinolite and very often encompassed by films of chlorite related to the greenschist facies retrometamorphism. Plagioclase is highly replaced by epidote and has an albitic composition $\left(\mathrm{An}_{0.7-2.4}\right)$ that is probably also a result of the greenschist facies retrometamorphism and hydrothermal alteration. The least deformed rocks present original subhedral granular texture and minor intergranular texture domains (Fig. 4F). In the deformed rocks, the foliation is well marked by the preferential orientation of amphiboles and chlorite. In narrow shear zones, milonites are formed and the hornblende and plagioclase are fully substituted by actionolite 
and epidote, respectively. Subordinated to the metadiorites occur highly deformed tonalitic intrusions composed of quartz, plagioclase (albite) and Mg-hornblende. In these rocks, the hornblende is replaced by actinolite and chlorite, and the plagioclase is strongly saussuritized.
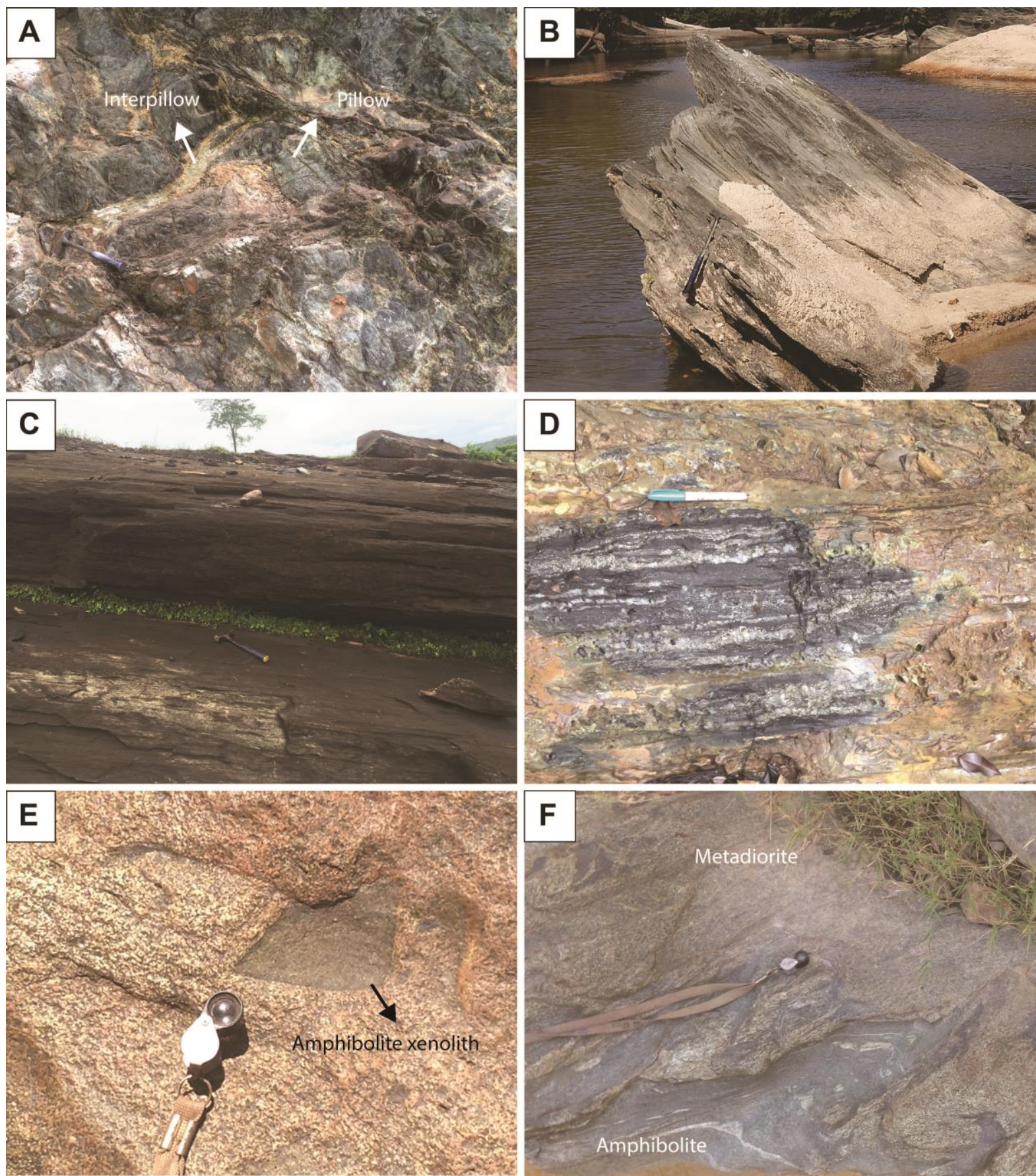

Fig. 3. Field characteristics of metavolcanic and metaplutonic rocks of the Faina and Serra de Santa Rita greenstone belts. (A) Pillow lavas in ultramafic rocks. (B) Foliated amphibolite outcrop. (C) Foliated metandesite outcrop. (D) Intercalation of metachert and carbonaceous schist that are associated with metandesites and metavolcanoclastic rocks. (E) Angular fine-grained amphibolite (metabasalt) xenolith in coarse-grained metadiorite. (F) Irregular contact between metadiorite (upper) and amphibotite (lower). 

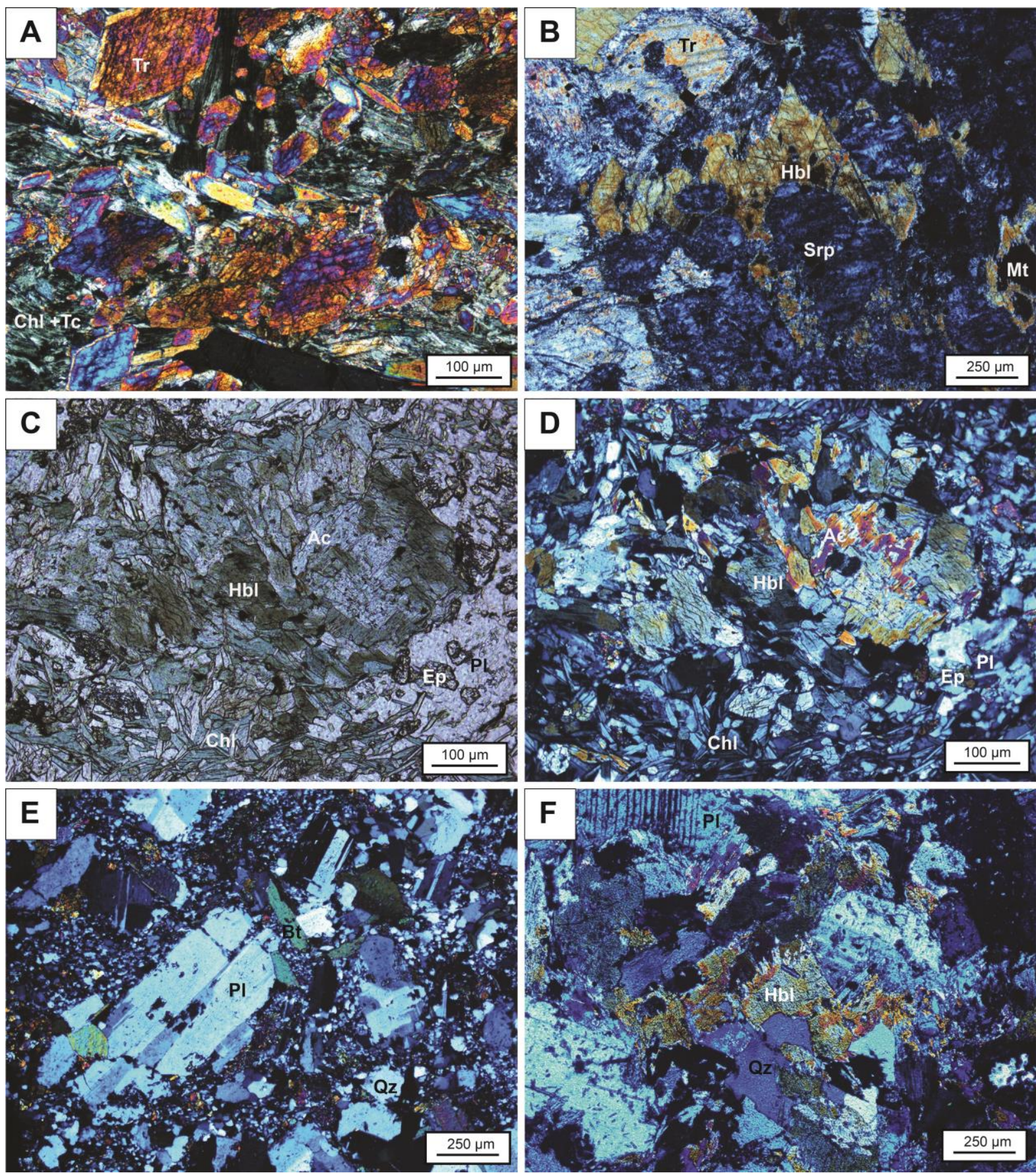

Fig. 4. Photomicrographs of metavolcanic and metaplutonic rocks of the Faina and Serra de Santa Rita greenstone belts. (A) Tremolite porphyroblasts in ultramafic schist composed of tremolite, chlorite and talc. (B) Pseudomorphs of olivine totally serpentinized and encompassed by Mg-hornblende and tremolite. (C-D) Amphibolite composed of Mg-hornblende partially substituted by actinolite and chlorite, and plagioclase replaced by epidote. (E) Metandesite with preserved plagioclase phenocrysts embedded in a fine-grained groundmass of quartz, plagioclase, muscovite and biotite. (F) Metadiorite composed of Mg-hornblende, plagioclase and quartz with original integranular texture. Crossed polarized light: A, B, D, E and F. Plane polarized light: D. Abreviations: Ac (actinolite); Chl (chlorite); Ep (epidote); Hbl (hornblende); Mt (magnetite); Pl (plagioclase); Qz (quartz); Tr (tremolite). 


\section{Whole rock geochemistry}

\subsection{Major and trace elements}

\subsubsection{Ultramafic rocks and chloritites}

The ultramafic rocks of the Faina and Serra de Santa Rita greenstone belts are characterized by $\mathrm{SiO}_{2}=45-55$ wt. $\%, \mathrm{MgO}=20-32$ wt. $\%, \mathrm{Fe}_{2} \mathrm{O}_{3}=9-16$ wt. $\%, \mathrm{Al}_{2} \mathrm{O}_{3}=3-8$ wt. $\%$, $\mathrm{TiO}_{2}=0.1-0.6$ wt. $\%, \mathrm{P}_{2} \mathrm{O}_{5}=0.01-0.06$ wt. $\%, \mathrm{Ni}=905-2560$ ppm, $\mathrm{Cr}=1320-2910$ ppm and $\# \mathrm{Mg}=75-87$ (Table 3). The ultramafic rocks have low REE contents ( $\left.\sum \mathrm{REE}=5-43 \mathrm{ppm}\right)$ and on chondrite-normalized diagram show flat to enriched LREE patterns $\left(\mathrm{La} / \mathrm{Sm}_{\mathrm{cn}}=1.01-4.27\right.$, $\left.\mathrm{La} / \mathrm{Yb}_{\mathrm{cn}}=0.61-6.36\right)$ and flat to slightly fractionated HREE patterns ( $\left.\mathrm{Gd} / \mathrm{Yb}_{\mathrm{cn}}=0.59-1.94\right)$. Ushaped REE patterns, marked by MREE depletion relative to LREE and HREE, are observed in two samples (TF14-075B and TF14-II-125A). Negative Ce anomalies are presented in some samples $(\mathrm{Ce} / \mathrm{Ce} *=0.24-0.77)$, while a pronounced negative Eu anomaly $\left(\mathrm{Eu} / \mathrm{Eu}^{*}=0.55\right)$ is only observed in the sample TF14-00 (Fig. 5A). On primitive mantle-normalized diagram these rocks show variable negative $\mathrm{Nb}$, $\mathrm{Ti}$ and $\mathrm{Zr}$ anomalies (Fig. 5B).

The chloritites of the Faina and Serra de Santa Rita greenstone belts are characterized by high $\mathrm{MgO}=28-31$ wt.\% and $\# \mathrm{Mg}=77-82$ and differ from the other ultramafic rocks by the lower contents of $\mathrm{SiO}_{2}$ (31-32 wt.\%), Ni (110-410 ppm) and $\mathrm{Cr}$ (80-940 ppm), and by higher contents of $\mathrm{Al}_{2} \mathrm{O}_{3}$ (21-23 wt.\%), $\mathrm{TiO}_{2}$ (1.0-1.4 wt.\%), $\mathrm{P}_{2} \mathrm{O}_{5}$ (0.1-0.4 wt.\%) and REE ( $\left.\sum \mathrm{REE}=93-303 \mathrm{ppm}\right)$ (Table 3). On chondrite-normalized diagram, the chloritites show LREE enrichment $\left(\mathrm{La} / \mathrm{Sm}_{\mathrm{cn}}=3.91-4.97, \mathrm{La} / \mathrm{Yb}_{\mathrm{cn}}=11.12-27\right)$ and HREE depletion $\left(\mathrm{Gd} / \mathrm{Yb}_{\mathrm{cn}}\right.$ $=1.60-3.58)$, with negative to positive $\mathrm{Eu}$ anomalies $\left(\mathrm{Eu} / \mathrm{Eu}^{*}=0.72-1.40\right)$ (Fig. 5C). On

primitive mantle-normalized diagram, the chloritites present pronounced negative $\mathrm{Nb}$ anomalies $\left(\mathrm{Nb} / \mathrm{Th}_{\mathrm{pm}}=0.09-0.41\right)$ and negative to positive $\mathrm{Zr}\left(\mathrm{Zr} / \mathrm{Sm}_{\mathrm{pm}}=0.79-2.14\right)$ and $\mathrm{Ti}$ $\left(\mathrm{Ti} / \mathrm{Sm}_{\mathrm{pm}}=0.24-0.60\right)$ anomalies (Fig. 5D). 

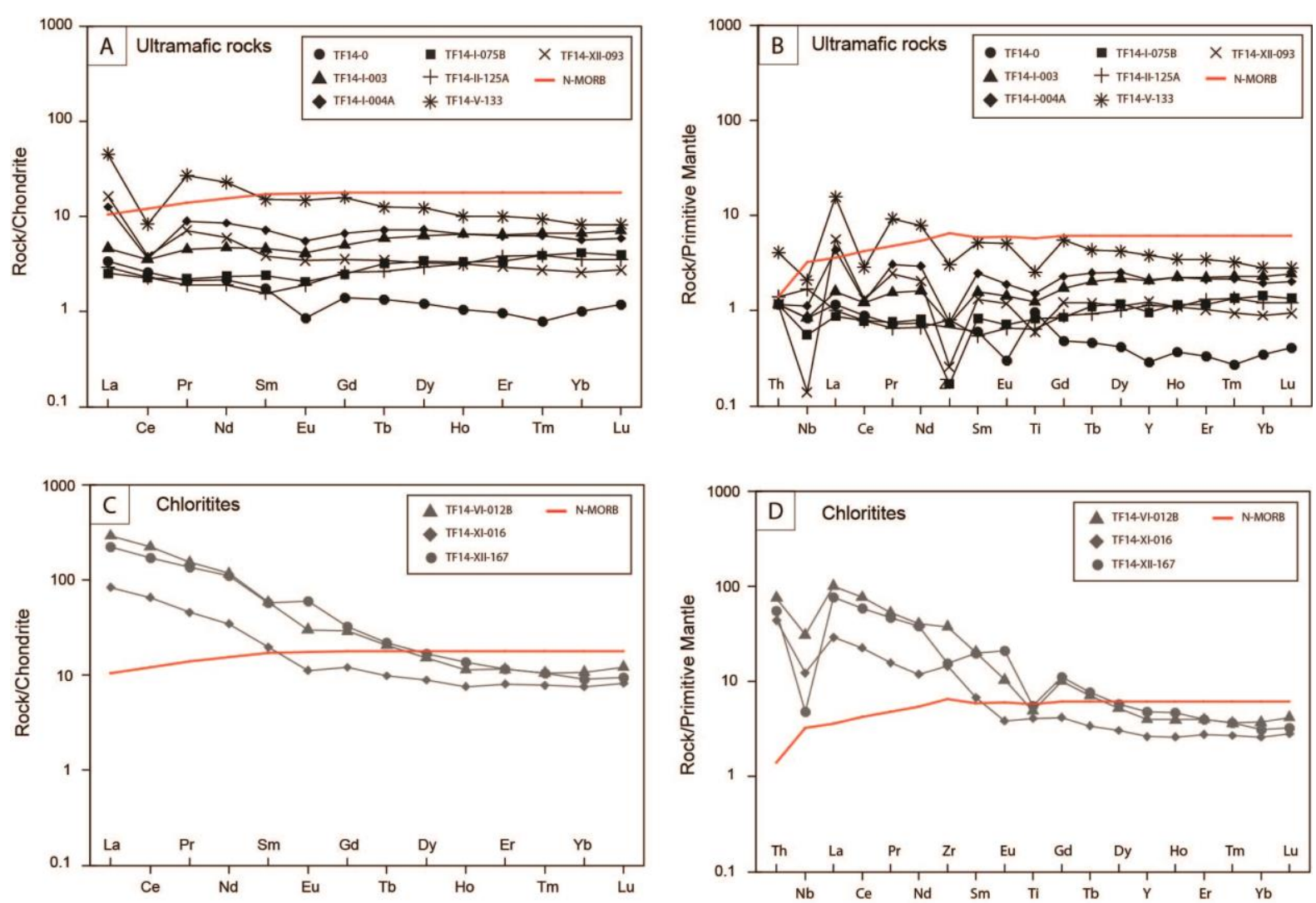

Fig. 5. Chondrite and primitive mantle-normalized diagrams for ultramafic rocks and chloritites of the Faina and Serra de Santa Rita greenstone belts. (A-B) Ultramafic schists and cumulate-textured rocks. (C-D) Chloritites. Normalization values and N-MORB composition are those of Sun and McDonough (1989).

\subsubsection{Amphibolites}

The amphibolites of the Serra de Santa Rita greenstone belt are characterized by $\mathrm{SiO}_{2}=53-55$ wt. $\%, \mathrm{Al}_{2} \mathrm{O}_{3}=9-16$ wt. $\%, \mathrm{Fe}_{2} \mathrm{O}_{3}=9-12$ wt.\%, $\mathrm{MgO}=7-15$ wt.\%, $\mathrm{CaO}=6-13$ wt.\%, $\mathrm{TiO}_{2}=0.4-1.2$ wt.\% and $\# \mathrm{Mg}=56-72$ (Table 3). These rocks are classified as basalts on $\mathrm{Nb} / \mathrm{Y}$ vs $\mathrm{Zr} / \mathrm{Ti}$ diagram and only one sample (TF14-XII-178) plots in the limit of the alkali basalts field due to the high $\mathrm{Nb}$ content (Fig. 6A). Based on the trace-elements behavior, the amphibolites can be subdivided into two groups: type 1 basalts and type 2 basalts. The type 1 basalts are characterized by the highest contents of $\mathrm{MgO}$ (9-15 wt.\%), Mg\# (60-72), Cr (5701280 ppm) and $\mathrm{Ni}$ (191-384 ppm), show toleiitic magmatic affinity on Y vs Zr and $\mathrm{Yb}$ vs $\mathrm{La}$ diagrams (Figs. 6B and 6C), and have the lowest absolute REE contents ( $\sum \mathrm{REE}=15-28 \mathrm{ppm}$ ). On chondrite-normalized diagram, the type 1 basalts have relatively flat REE patterns marked by $\mathrm{La} / \mathrm{Sm}_{\mathrm{cn}}=0.94-1.14, \mathrm{La} / \mathrm{Yb}_{\mathrm{cn}}=0.75-1.53$ and $\mathrm{Gd} / \mathrm{Yb}_{\mathrm{cn}}=1.00-1.67$. Slightly positive $\mathrm{Eu}$ anomaly $\left(\mathrm{Eu} / \mathrm{Eu}^{*}=1.24\right)$ is observed in one of the samples (PFG-CA-19A) (Fig. 7A). On 
primitive mantle-normalized diagram, the type 1 basalts show relatively flat patterns without any significant anomalies (Fig. 7B).

The type 2 basalts are characterized by lower MgO (7-9 wt.\%), Mg\# (56-67), Cr (340$430 \mathrm{ppm})$ and $\mathrm{Ni}(110-237 \mathrm{ppm})$ and by higher REE contents $\left(\sum E T R=60-82 \mathrm{ppm}\right)$ compared to the type 1 basalts. Two samples (TF14-XII-015B and PFG-CA-16A) show sub-alkaline transitional magmatic affinity and one sample (TF14-XII-178) show calc-alkaline magmatic affinity according to $\mathrm{Y} v s \mathrm{Zr}$ and $\mathrm{Yb}$ vs La diagrams (Figs. 6B and 6C). On chondritenormalized diagram, the type 2 basalts have enriched LREE patterns and flat to slightly depleted HREE patterns marked by $\mathrm{La} / \mathrm{Sm}_{\mathrm{cn}}=1.62-2.73, \mathrm{La} / \mathrm{Yb}_{\mathrm{cn}}=1.93-2.3$ e $\mathrm{Gd} / \mathrm{Yb}_{\mathrm{cn}}=1.31-$ 1.95, without $\mathrm{Eu}$ anomalies (Fig. 7C). On primitive mantle-normalized diagram, the type 2 basalts show slightly negative to positive $\mathrm{Nb}$ anomalies $\left(\mathrm{Nb} / \mathrm{Th}_{\mathrm{pm}}=0.68-1.27\right)$ and negative $\mathrm{Ti}$ anomalies $\left(\mathrm{Ti} / \mathrm{Sm}_{\mathrm{pm}}=0.49-0.84\right)$ (Fig. 7D). The type 2 basalts are also characterized by high $\mathrm{Nb}$ contents (5-12 ppm), whereas the type 1 basalts present low values (1-2 ppm) (Table 3$)$. 
A

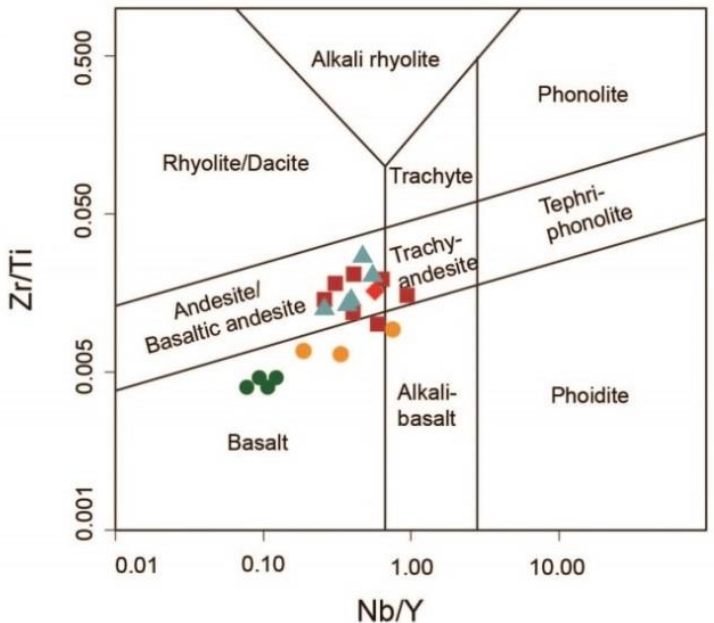

B

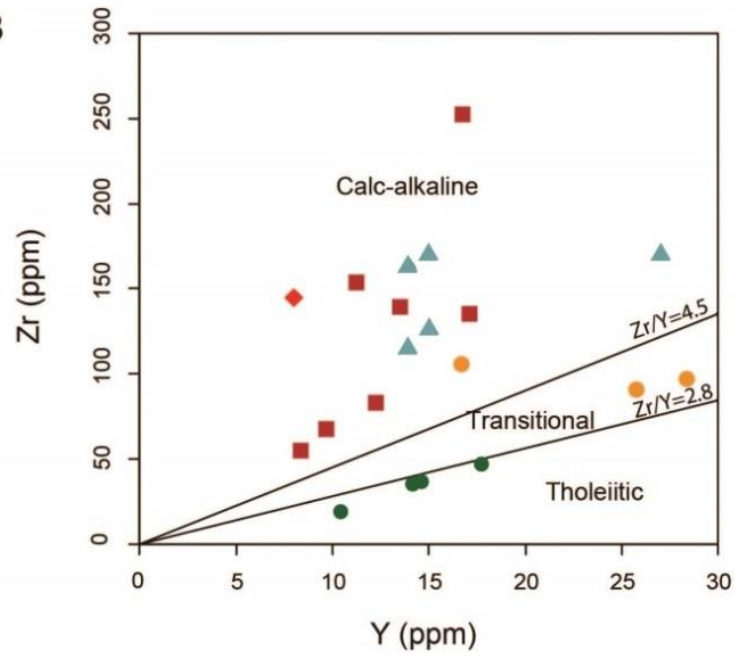

- Amphibolites (Type 1 Basalts)

- Amphibolites (Type 2 Basalts)

Metandesites

- Metadiorites

Metatonalite

C

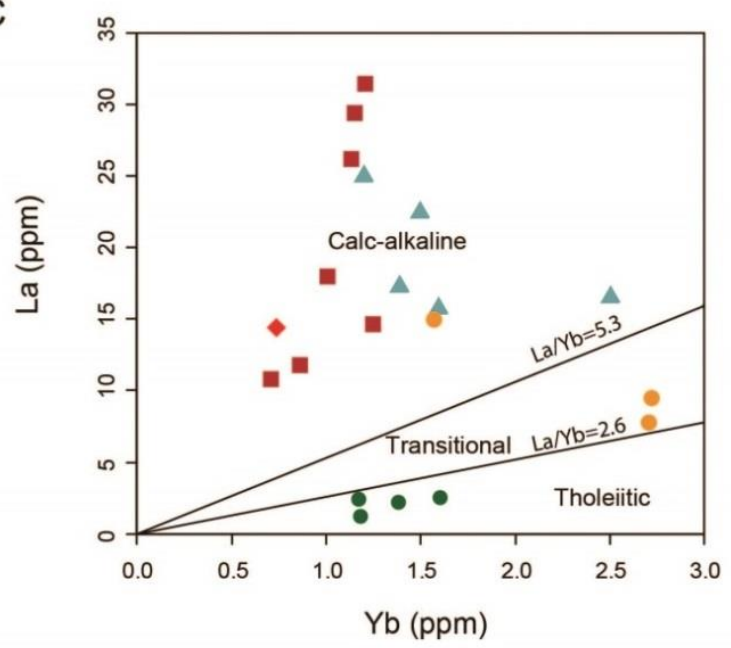

Fig. 6. Classification diagrams for metavolcanic and metaplutonic rocks of the Faina and Serra de Santa Rita greenstone belts. (A) Nb/Y vs. Zr/Ti classification diagram (Winchester and Floyd, 1977). (B-C) Y vs. Zr and Yb vs. La discriminant diagrams of magmatic affinity (Ross and Bédard, 2009). 

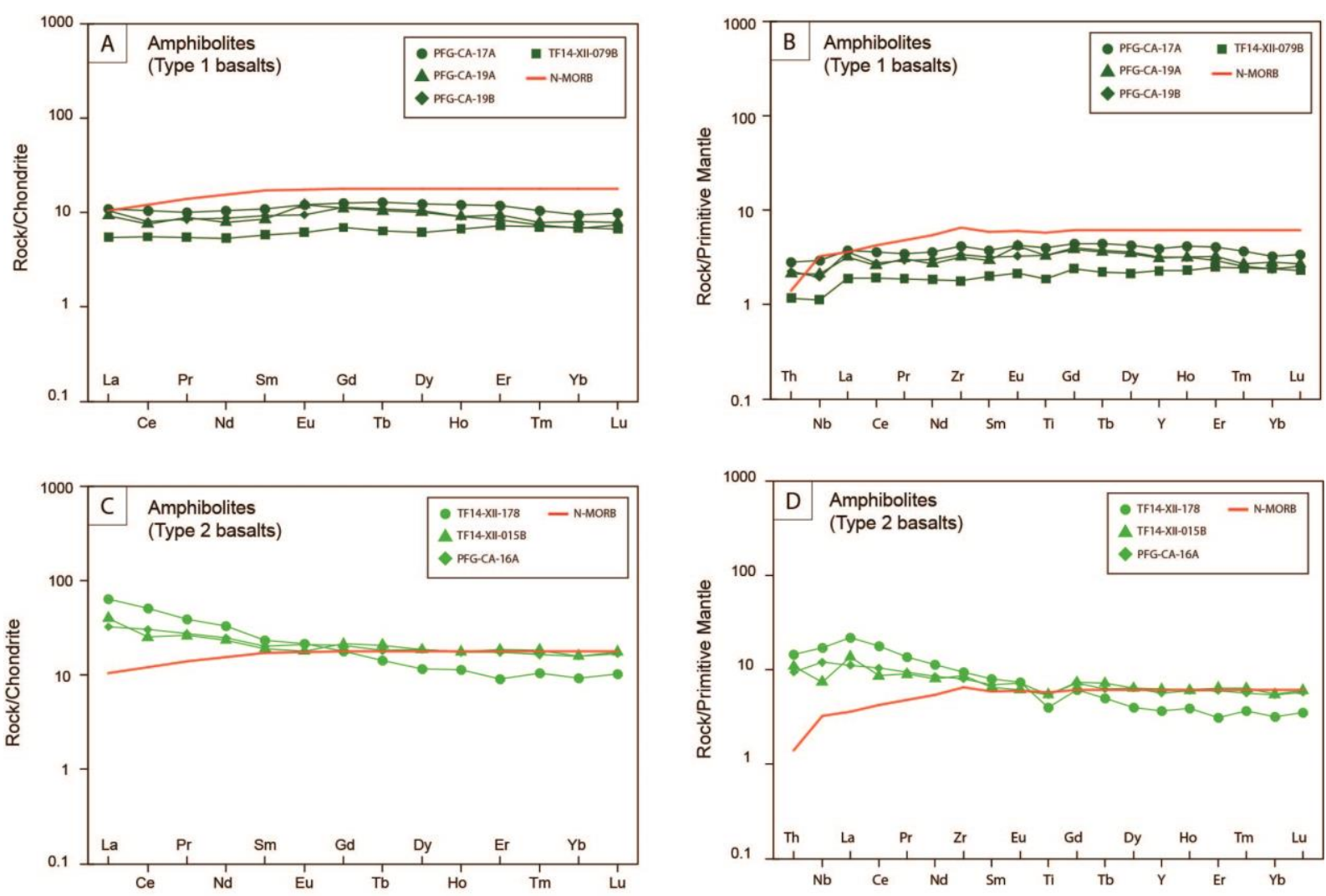

Fig. 7. Chondrite and primitive mantle-normalized diagrams for amphibolites of the Faina and Serra de Santa Rita greenstone belts. (A-B) Amphibolites of the type 1 basalts group. (C-D) Amphibolites of the type 2 basalts group. Normalization values and N-MORB composition are those of Sun and McDonough (1989).

\subsubsection{Metandesites}

The metandesites of the Serra de Santa Rita greenstone belts are characterized by $\mathrm{SiO}_{2}=56-68$ wt. $\%, \mathrm{Al}_{2} \mathrm{O}_{3}=16-20$ wt. $\%, \mathrm{Fe}_{2} \mathrm{O}_{3}=5-8$ wt. $\%, \mathrm{Na}_{2} \mathrm{O}=4-6$ wt. $\%, \mathrm{CaO}=3-6$ wt. $\%$, $\mathrm{MgO}=3-6$ wt. $\%, \mathrm{TiO}_{2}=0.5-1.1$ wt. $\%, \mathrm{~K}_{2} \mathrm{O}=0.1-1.4$ wt. $\%, \mathrm{Cr}=60-240$ ppm and $\mathrm{Ni}=51-128$ ppm (Table 3). These rocks are classified as andesites and basaltic andesites on $\mathrm{Nb} / \mathrm{Y}$ vs $\mathrm{Zr} / \mathrm{Ti}$ diagram (Fig. 6A) and have calc-alkaline magmatic affinity according to $\mathrm{Y} v s \mathrm{Zr}$ and $\mathrm{Yb} v s$ La diagrams (Figs. 6B and 6C). On chondrite-normalized diagram, the metandesites have enriched LREE patterns and depleted HREE patterns marked by $\mathrm{La} / \mathrm{Sm}_{\mathrm{cn}}=2.55-4.12$, $\mathrm{La} / \mathrm{Yb}_{\mathrm{cn}}=4.70-14.58$ and $\mathrm{Gd} / \mathrm{Yb}_{\mathrm{cn}}=1.66-2.34$ (Fig. 8A). On primitive mantle-normalized diagram, the metandesites show pronounced negative $\mathrm{Nb}$ and $\mathrm{Ti}$ anomalies $\left(\mathrm{Nb} / \mathrm{Th}_{\mathrm{pm}}=0.26-\right.$ 0.35; $\left.\mathrm{Ti} / \mathrm{Sm}_{\mathrm{pm}}=0.08-0.16\right)$, and slightly positive $\mathrm{Zr}$ anomalies $\left(\mathrm{Zr} / \mathrm{Sm}_{\mathrm{pm}}=1.35-1.71\right)$ (Fig. 8B). 


\subsubsection{Metadiorites and metatonalites}

The metadiorites of the Serra de Santa Rita greenstone belt are characterized by $\mathrm{SiO}_{2}=54-58$ wt. $\%, \mathrm{Al}_{2} \mathrm{O}_{3}=13-15$ wt. $\%, \mathrm{MgO}=9-15$ wt. $\%, \mathrm{Fe}_{2} \mathrm{O}_{3}=7-10$ wt.\%, $\mathrm{CaO}=5-7$ wt.\%, $\mathrm{Na}_{2} \mathrm{O}=1-5$ wt.\%, $\mathrm{TiO}_{2}=0.4-1.2$ wt. $\%$ and $\mathrm{K}_{2} \mathrm{O}=0.1-1.4$ wt. $\%$. These rocks present unusual high \#Mg (70-81), Cr (440-1060 ppm) and Ni (200-456 ppm) contents (Table 3). The only analyzed sample of metatonalite (TF14-XII-183) show higher $\mathrm{SiO}_{2}$ (66 wt.\%) and lower $\mathrm{Fe}_{2} \mathrm{O}_{3}$ (5 wt.\%), $\mathrm{MgO}$ (1.7 wt.\%), \#Mg (42), Cr (330 ppm) and Ni (120 ppm) than the metadiorites (Table 3). On TAS classification diagram for plutonic rocks (Middlemost, 1994; not presented), the rocks plot predominantly in the field of quartz-diorites with the exception of the metatonalite sample, that plots consistently in the tonalite field. The metadiorites and metatonalite plot predominantly in the andesite and basaltic andesite field on $\mathrm{Nb} / \mathrm{Yb}$ vs $\mathrm{Zr} / \mathrm{Ti}$ diagram (Fig. 6A), and show calc-alkaline magmatic affinity on $\mathrm{Y} v s \mathrm{Zr}$ and $\mathrm{Yb} v s \mathrm{La}$ diagrams (Figs. 6B and 6C).

The metadiorites and metatonalites are characterized by $\sum \mathrm{ETR}=50-162 \mathrm{ppm}$ and on chondrite-normalized diagram they present enriched LREE patterns and depleted HREE patterns marked by $\mathrm{La} / \mathrm{Sm}_{\mathrm{cn}}=2.91-4.18, \mathrm{La} / \mathrm{Yb}_{\mathrm{cn}}=8.49-18.61$ and $\mathrm{Gd} / \mathrm{Yb}_{\mathrm{cn}}=1.75-3.93$. Only the metatonalite sample shows positive Eu anomaly $\left(\mathrm{Eu} / \mathrm{Eu}^{*}=1.30\right)$ (Fig. 8C). On primitive mantle-normalized diagram the metadiorites present pronounced negative $\mathrm{Nb}$ and $\mathrm{Ti}$ anomalies $\left(\mathrm{Nb} / \mathrm{Th}_{\mathrm{pm}}=0.22-0.84 ; \mathrm{Ti} / \mathrm{Sm}_{\mathrm{pm}}=0.24-0.45\right)$, and slightly negative $\mathrm{Zr}$ anomalies $\left(\mathrm{Zr} / \mathrm{Sm}_{\mathrm{pm}}=0.83-0.92\right)$ (Fig. 8D). 

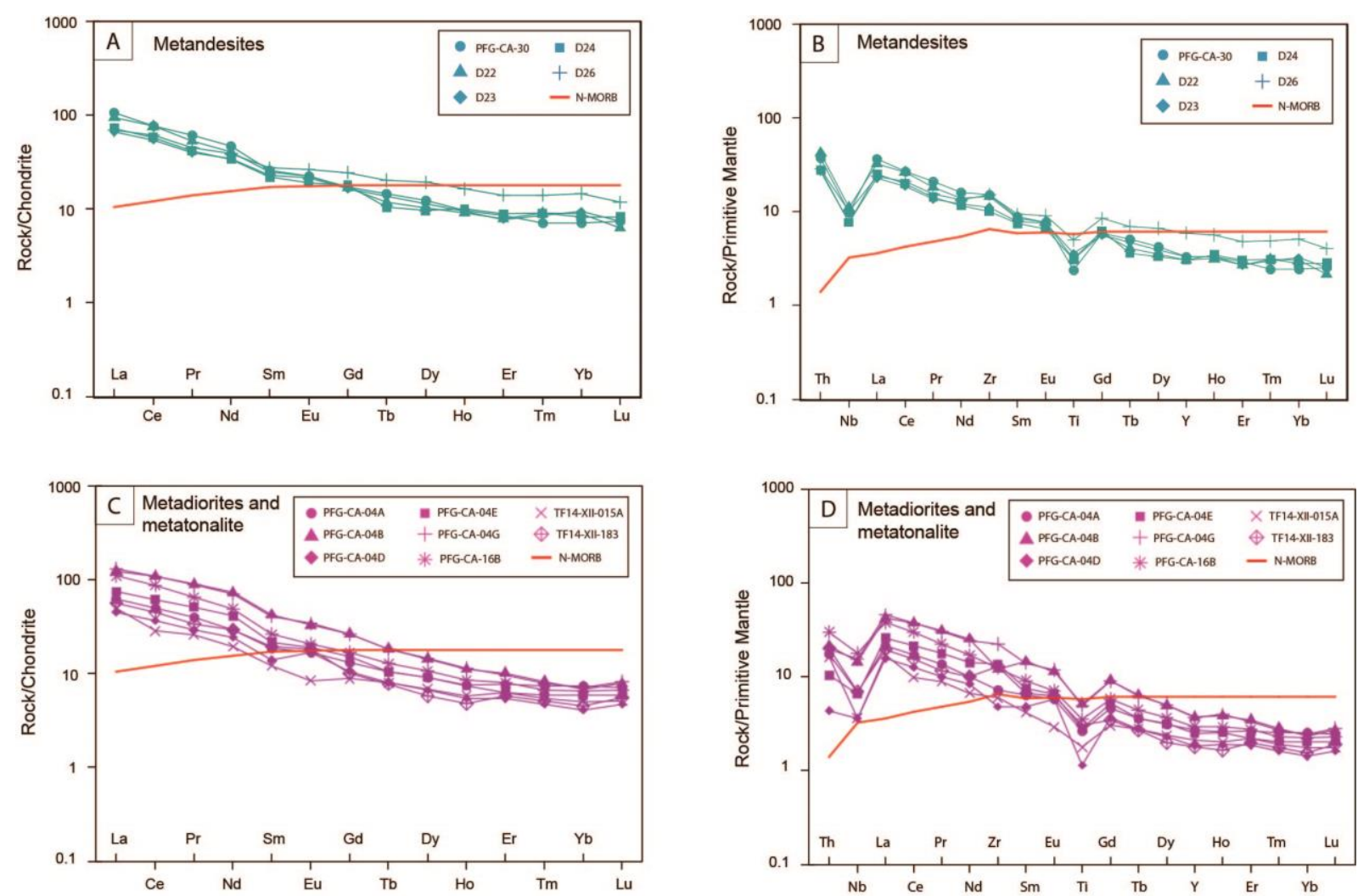

Fig. 8. Chondrite and primitive mantle-normalized diagrams for metandesites, metadiorites and metatonalites of the Faina and Serra de Santa Rita greenstone belts. (A-B) Metandesites. (C-D) Metadiorites and metatonalites. Normalization values and N-MORB composition are those of Sun and McDonough (1989).

\section{Geochronology}

\section{1. $U-P b$}

LA-MC-ICP-MS and LA-SF-ICP-MS U-Pb zircon dating were conducted in five samples: a chloritite from the Faina greenstone belt (TF14-I-099), a chloritite from the Serra de Santa Rita greenstone belt (TF14-XI-016), an amphibolite that belong to the type 2 basalts group (TF14-XII-178), a metadiorite (PFG-CA-04A) and a metatonalite (TF1-XII-183). With the exception of the sample TF14-XI-016, the zircon crystals data of all samples provided discordia diagrams and ages defined by upper intercepts, interpreted as the magmatic crystallization ages of the protoliths. Lower intercepts have a high associated error, but when indicating ages between 500 and 900 Ma may reflect the Neoproterozoic Brasiliano Cycle resetting of $\mathrm{U}-\mathrm{Pb}$ system.

The chloritite sample of the Faina greenstone belt yielded a discordia defining the upper intercept age of 2921 \pm 64 Ma (Fig. 9A). The chloritite sample of the Serra de Santa Rita greenstone belt yielded the concordant age of 2960.3 \pm 5.5 Ma (Fig. 9B). The amphibolite 
sample yielded a discordia defining the upper intercept age of 2959.5 $\pm 6.1 \mathrm{Ma}$ (Fig. 9C). The metadiorite sample yielded a discordia defining the upper intercept age of $2922.8 \pm 2.8 \mathrm{Ma}$ (Fig. 9D). The metatonalite sample yielded a discordia defining the upper intercept age of $2794 \pm 14 \mathrm{Ma}$ (Fig. 9E). These ages mark two main periods of igneous activity: 2.96-2.92 Ga and $2.79 \mathrm{Ga}$.
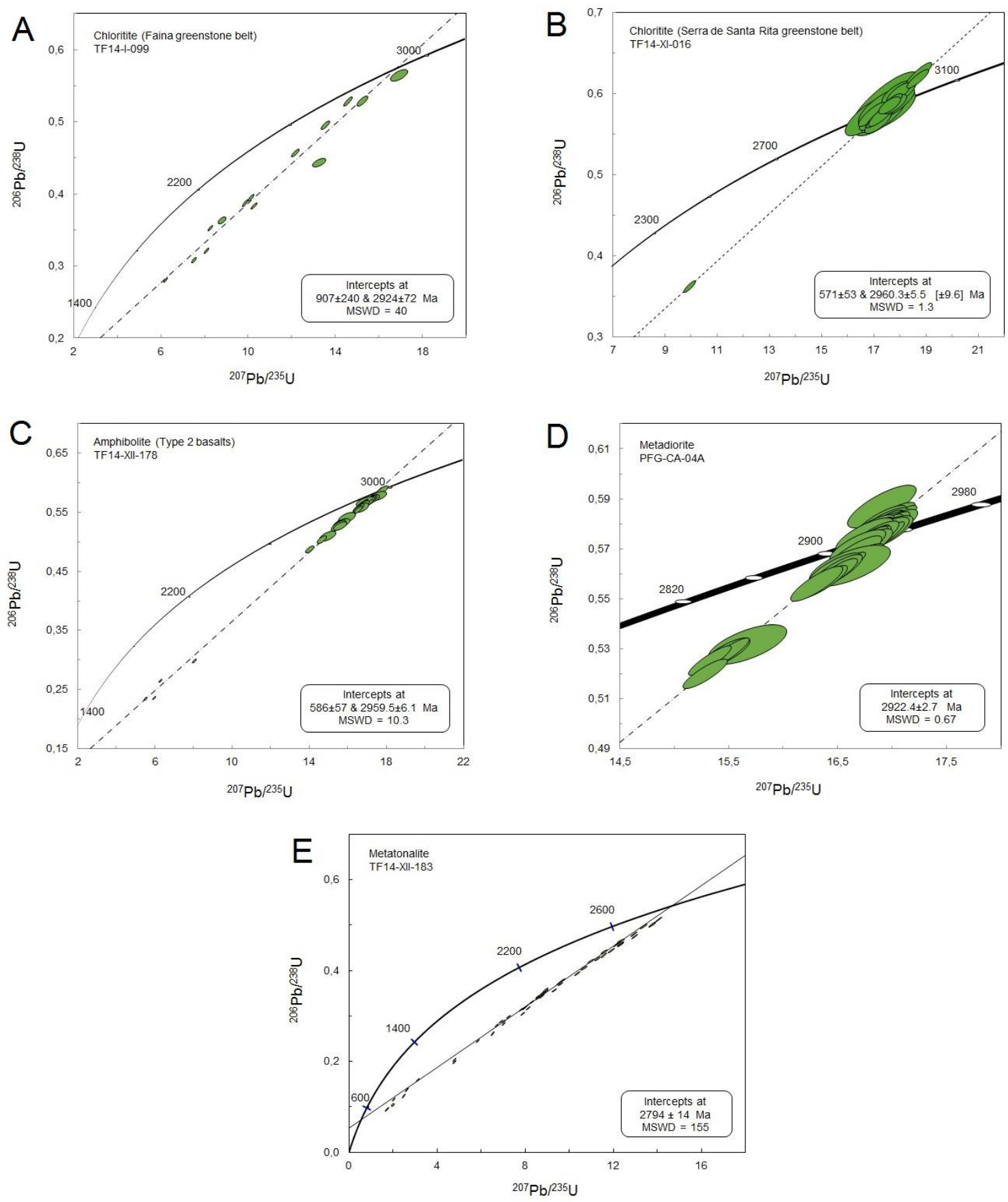

Fig. 9. LA-ICP-MS U-Pb zircon ages of metavolcanic and metaplutonic rocks of Faina and Serra de Santa Rita greenstone belts. (A) TF14-I-099 (chloritite of the Faina greenstone belt). (B) TF14-XI-016 (chloritite of the 
Serra de Santa Rita greenstone belt). (C) TF14-XII-178 (amphibolite of the type 2 basalts group). (D) PFG-CA04A (metadiorite) and (E) TF14-XII-183 (metatonalite).

\section{2. $\mathrm{Sm}-\mathrm{Nd}$}

The whole-rock Sm-Nd isotopic analyses were carried out in four samples: an amphibolite of the type 2 basalts group (TF14-XII-178), two metadiorites (PFG-CA-04A and PFG-CA-04E), and a metatonalite (TF14-XII-183). The amphibolite presented $\mathrm{T}_{\mathrm{DM}}=3.08 \mathrm{Ga}$ and $\varepsilon_{\mathrm{Nd}}=2.18$ for the magmatic crystallization age of $2.96 \mathrm{Ga}$. The metadiorites PFG-CA-04A and PFG-CA-04E presented, respectively, $\mathrm{T}_{\mathrm{DM}}$ of 3.03 and $2.99 \mathrm{Ga}$, and $\varepsilon \mathrm{Nd}$ of 2.18 and 2.77 for the magmatic crystallization age of $2.92 \mathrm{Ga}$. The metatonalite presented $\mathrm{T}_{\mathrm{DM}}=3.13 \mathrm{Ga}$ and $\varepsilon N d=-0.30$ for the magmatic crystallization age of $2.79 \mathrm{Ga}$ (Table 5).

\section{Discussion}

\subsection{Element mobility and crustal contamination}

The recognition of the primary chemical composition of igneous rocks in Archean greenstone belts sometimes is difficult due to the effects of metamorphism, hydrothermal alteration and deformation. The metavolcanic and metaplutonic rocks of the Faina and Serra de Santa Rita greenstone belts were submitted to at least two thermal-tectonic events under greenschist to amphibolite conditions and to several deformation degrees. Nonetheless, several studies have demonstrated that in Archean volcanic rocks exposed to hydrothermal alteration and to greenschist to amphibolite facies metamorphism, the elements $\mathrm{Al}, \mathrm{Ti}, \mathrm{Fe}, \mathrm{P}$, HFSE (Th, Nb, Ta, Zr and Hf), REE and transition metals (Cr, Ni, Sc, V, Y e Co) are relatively immobile, while the elements $\mathrm{Na}, \mathrm{K}, \mathrm{Ca}, \mathrm{LILE}(\mathrm{Cs}, \mathrm{Rb}, \mathrm{Ba}$ e $\mathrm{Sr}$ ) and $\mathrm{Pb}$ tend to be mobile (Hart et al., 1974; Condie et al., 1977; Kerrich and Fryer, 1979; Dostal et al., 1980; Ludden et al., 1982; Murphy and Hynes, 1986; Arndt, 1994; Polat and Hofmann, 2003). Therefore, in this study the geochemical data discussions are focused mainly on the elements that are relatively immobile during post-magmatic processes.

The ultramafic rocks of the Faina and Serra de Santa Rita greenstone belts are commonly associated with high loss on ignition (LOI=4-11 wt.\%) and four of these samples present pronounced negative $\mathrm{Ce}$ anomalies $\left(\mathrm{Ce} / \mathrm{Ce}^{*}=0.24-0.77\right)$. Samples with $\mathrm{Ce} / \mathrm{Ce} *<0.9$ and $\mathrm{Ce} / \mathrm{Ce}^{*}>1.1$ are considered "highly altered" and present LREE mobility (Polat and Hofmann, 2003). Thus, the ultramafic rocks with strong negative Ce anomalies must have suffered some kind of trace-element mobility. Three amphibolite samples (TF14-XII-015B, 
PFG-CA-19A e PFG-CA-19B) and one metadiorite sample (TF14-XII-015A) also present $\mathrm{Ce} / \mathrm{Ce}^{*}$ values lower than 0.9 , although the chondrite- and primitive mantle-normalized patterns of these rocks are coherent with the other samples without $\mathrm{Ce}$ anomalies on the corresponding geochemical diagrams. Therefore, we consider that the geochemical signature of these rocks might also be used in the interpretation of their original chemical composition.

The evaluation regarding crustal contamination in the precursor magma of the Faina and Serra de Santa Rita greenstone belts can be assessed on the basis of the pillow lava structures in ultramafic rocks and the spatial association of metachert and carbonaceous schist interlayered with amphibolites and metandesites. Such characteristics are more consistent with an oceanic rather than a continental setting for the volcanism. The positive initial $\mathrm{ENd}$ values (2.18-2.77) observed in the amphibolite and metadiorites with magmatic crystallization ages between 2.96 and $2.92 \mathrm{Ga}$ are also not consistent with continental crust interaction in this period. The metatonalite that presented magmatic crystallization age of $2.79 \mathrm{Ga}$ and initial $\varepsilon \mathrm{Nd}$ of $-0,30$ indicates that interaction with continental crust occurred in this second period.

\subsection{Origin of the ultramafic rocks and similarities with boninites}

Spinifex textures are well described in metakomatiites of the Crixás greenstone belt, in the northern portion of the Archean-Paleoproterozoic Terrane of Goiás (Teixeira et al., 1981; Teixeira et al., 1981; Kuyumjian \& Teixeira, 1982), but textures of this kind are not yet recognized in the Faina and Serra de Santa Rita greenstone belts. However, the presence of pillowed structures in ultramafic rocks of the Serra de Santa Rita greenstone belt is extremely important because it indicates the subaqueous volcanic character of these sequences. Therefore, the ultramafic protholiths of the Faina and Serra de Santa Rita greenstone belts are correlated to komatiites.

The komatiites are traditionally divided into two groups: alumina depleted komatiites (ADK) and alumina undepleted komatiites (AUK) (Nesbitt et al., 1979; Arndt, 1994). The ADK are characterized by low $\mathrm{Al}_{2} \mathrm{O}_{3} / \mathrm{TiO}_{2}(\leq 10)$, high $\mathrm{CaO} / \mathrm{Al}_{2} \mathrm{O}_{3}(\sim 1.5)$ and $\mathrm{Gd} / \mathrm{Yb}_{\mathrm{cn}}=1.1-$ 1.7. The AUK have nearly chondritic $\mathrm{Al}_{2} \mathrm{O}_{3} / \mathrm{TiO}_{2}$ ratios ( 20), $\mathrm{CaO} / \mathrm{Al}_{2} \mathrm{O}_{3}(\sim 1)$ and flat chondrite-normalized HREE patterns. The ultramafic rocks of the Faina and Serra de Santa Rita greenstone belts are characterized by $\mathrm{Al}_{2} \mathrm{O}_{3} / \mathrm{TiO}_{2}(12.3-44.8), \mathrm{CaO} / \mathrm{Al}_{2} \mathrm{O}_{3}(0.6-1.1)$ and $\mathrm{Gd} / \mathrm{Yb}_{\mathrm{cn}}(0.7-1.9)$ ratios quite varied, which hinders their classification into one of the two komatiite groups, although they still present more similarity with AUK. This complexity may 
be related to different sources for komatiitic lava in the region, but the element mobility due to post-magmatic processes cannot be disregarded.

The origin of komatiites in greenstone belts has been commonly attributed to hightemperature mantle plumes generating a typical tholeiite-komatiite association (e.g. Campbell et al., 1989; Herzberg, 1992; Xie et al., 1993; Arndt, 1994; Condie, 1994; Dostal and Mueller, 1997, 2004; Puchtel et al., 1998; Polat, 2009). Nonetheless, studies have also suggested an origin related to subduction zones, in forearc enviroments, for some Archean komatiites and komatiitic basalts in analogy with Phanerozoic boninites (e.g. Barberton greenstone belt; Parman et al., 2001, 2004; Parman and Grove, 2004).

The boninites are characterized by high $\mathrm{SiO}_{2}(>53$ wt.\%) and \#Mg (>60), and low $\mathrm{TiO}_{2}(<0.5$ wt.\%) and are exclusive of subduction zones. The boninitic magmas are generated by hydrous melting of a refractory mantle at shallow depths (Crawford et al., 1989). The boninites are normally associated to forearc regions in the initial stages of subduction in intraoceanic arcs (Pearce et al., 1992). According to experimental data, komatiitic magma can also be produced by mantle hydrous melting at relatively low temperatures, between 1500 and $1600^{\circ} \mathrm{C}$. These temperatures are significantly cooler than estimates of mantle temperatures assuming an anhydrous plume origin for komatiites $\left(>1900^{\circ} \mathrm{C}\right)$ (Parman et al., 2001).

The ultramafic rocks of the Faina and Serra de Santa Rita greenstone belts have some chemical characteristics comparable to boninites, such as low $\mathrm{TiO}_{2}(0.1-0.6 \mathrm{wt} . \%)$, negative $\mathrm{Nb}$ and $\mathrm{Ti}$ anomalies observed in some samples (Fig. 5B), and the U-shaped REE patterns, which are observed in three samples (TF14-000, TF14-075B and TF14-II-125A) (Fig. 5A). Based on these chemical characteristics and also on the context of the other metavolcanic and metaplutonic rocks associated with the ultramafic rocks of the Faina and Serra de Santa Rita greenstone belts, as will be discussed that are related to subduction zones, we suggest that the komatiites of the Faina and Serra de Santa Rita greenstone belts were generated by hydrous melting of a depleted mantle in a forearc setting, as analogous to boninites. The Mesoarchean high geothermal gradient favored the production of komatiitic magma in these environments. 


\subsection{Origin of the chloritites}

The mineralogy and chemical composition of the chloritites indicate that these rocks underwent intense hydrothermal alteration that resulted in the extremely low $\mathrm{SiO}_{2}(31-32$ wt.\%) and high $\mathrm{Al}_{2} \mathrm{O}_{3}$ (21-23 wt.\%). Even with the high values of loss on ignition (LOI=11 wt.\%), the chloritites do not present $\mathrm{Ce}$ anomalies $\left(\mathrm{Ce} / \mathrm{Ce}^{*}=0.98-1.06\right)$ like some of the Faina and Serra de Santa Rita ultramafic rocks. The chloritites are spatially related to ultramafic schists and cumulate-textured rocks, which may also suggest that the photolith of the chloritites could also be komatiites that were quite submitted to hidrotermal alteration. Nonetheless, the chloritites present chemical characteristics very different from those rocks.

The chloritites are characterized by enriched LREE patterns and negative $\mathrm{Nb}$ and $\mathrm{Ti}$ anomalies, typical features of subduction-related magmas (Perfit et al., 1980; Sauders et al., 1991; Hawkesworth et al., 1993; Pearce and Peate, 1995; Kelemen et al., 2003; Pearce, 2008). At subduction zones, the mantle wedge is metasomatized by slab-derived fluids produced by dehydration of the subducting oceanic crust. These fluids do not transport $\mathrm{Nb}$ and $\mathrm{Ta}$ (Tatsumi et al., 1986; Tatsumi and Nakamura, 1986), which are concentrated in the subducting slab and gives origin to the $\mathrm{Nb}$ and $\mathrm{Ta}$ depletion of arc magmas generated by fluid-induced melting of the mantle wedge. The magmas with subduction signature are also enriched in LILE and LREE, while the residual slab is recycled into the mantle (McColloch and Gamble, 1991).

Considering that the trace-element composition of the chloritites can be used to interpret the primary composition of their protholiths, it is likely that those protholiths are subduction-related. Although the ultramafic rocks of the Faina and Serra de Santa Rita greenstone belts are here interpreted as komatiites erupted in a forearc setting, similar to modern boninites, the chloritites differ from them by much higher $\mathrm{TiO}_{2}$ (1.0-1.4 wt.\%), $\mathrm{P}_{2} \mathrm{O}_{5}$ (0.1-0.4 wt.\%) and LREE enrichment. Moreover, the chondrite- and primitive mantlenormalized patterns of the chloritites (Figs. 5C and 5D) are similar to the metadiorites (Figs. 8C and 8D) and more less with the amphibolites (type 2 basalts group) patterns (Figs. 7C and 7D). These rocks present geochemical characteristics consistent with subduction zones, as will be discussed latter. The two chloritite samples that were dated also presented U-Pb zircon ages of 2.92 and $2.96 \mathrm{Ga}$, similar to the obtained ages for the metadiorite and amphibolite (type 2 basalts group) samples, respectively.

However, the pronounced $\mathrm{Nb}$ and $\mathrm{Ti}$ negative anomalies of the chloritites (Fig. 5C) are not observed in the amphibolites (Fig. 7D), and the $\mathrm{MgO}$ contents of the amphibolites 
$(\mathrm{MgO}=7-9$ wt.\%) are lower than those of the metadiorites $(\mathrm{MgO}=9-15$ wt.\%). The high $\mathrm{MgO}$ contents of the chloritites $(\mathrm{MgO}=28-31 \mathrm{wt} . \%)$ indicate that these rocks were formed from high-Mg precursors rocks. Thus, it is more likely that the chloritites have been generated from hydrothermalism (chloritization) acting in the high-Mg diorites that intruded the metavolcanic rocks of the Faina and Serra de Santa Rita greenstone belts. The formation of chloritites from the metamorphism and hydrothermalism of mafic and intermediate rocks is a common process, although in the Faina and Serra de Santa Rita greenstone belts it was not possible to obtain a direct field observation of the chloritites and their protholith.

\subsection{Type 1 basalts: back-arc basin basalts (BABB)}

The amphibolites corresponding to the type 1 basalts of the Serra de Santa Rita greenstone belt are characterized by tholeiitic magmatic affinity and flat chondrite-normalized REE patterns (Fig. 7A). These characteristics are similar to transitional MORB type basalts (T-MORB), but are also related to Phanerozoic oceanic plateau basalts (OPB) (e.g. Mahoney et al., 1995, Kerr et al., 1997) and to Archean intra-oceanic tholeiitic flows (e.g. Polat and Kerrich, 2000). Several of the Archean oceanic plateau tholeiitic basalts are interlayered with komatiites in a typical plume-related tholeiite-komatiite association (e.g. Campbell et al., 1989; Herzberg, 1992; Xie et al., 1993; Arndt, 1994; Condie, 1994; Dostal and Mueller, 1997, 2004; Puchtel et al., 1998; Polat, 2009). In general, the Phanerozoic OPB are chemically uniform, with $\mathrm{La} / \mathrm{Sm}_{\mathrm{cn}}=0.6-0.7, \mathrm{Ce} / \mathrm{Yb}_{\mathrm{cn}}=0.8-0.9$ and low $\mathrm{Zr} / \mathrm{Nb}(10-16), \mathrm{Zr} / \mathrm{Ta}(260-275)$ and $\mathrm{La} / \mathrm{Ta}$ (15-17) ratios (Floyd, 1989). However, the type 1 basalts of the Serra de Santa Rita greenstone belt are characterized by higher $\mathrm{La} / \mathrm{Sm}_{\mathrm{cn}}=0.9-1.1$ and $\mathrm{Ce} / \mathrm{Yb}_{\mathrm{cn}}=0.8-1.2$, and different $\mathrm{Zr} / \mathrm{Nb}=22-27, \mathrm{Zr} / \mathrm{Ta}=180-235$ and $\mathrm{La} / \mathrm{Ta}=11-13$ ratios than the average values of OPB.

$\mathrm{On} \mathrm{Nb} / \mathrm{Yb}$ vs. $\mathrm{Th} / \mathrm{Yb}$ and $\mathrm{Ta} / \mathrm{Yb}$ vs. Th/Yb diagrams, mantle plume-derived intraplate basalts and MORB without relation to subduction zones plot in the MORB-OIB field, while volcanic rocks related to subduction zones and crustal contamination plot obliquely and subparallel to the MORB-OIB field. This indicates addition of Th relatively to $\mathrm{Yb}$ by subduction processes or crustal assimilation. $\mathrm{On} \mathrm{Ta} / \mathrm{Yb} v s$. Th/Yb diagram, the type 1 basalts of the Serra de Santa Rita greenstone belt plot in the MORB-OIB field (Fig. 10B). However, on $\mathrm{Nb} / \mathrm{Yb} v s$. $\mathrm{Th} / \mathrm{Yb}$ diagram these rocks plot above the MORB-OIB field, in the region of the Phanerozoic back-arc basin basalts (BABB) (Fig. 10A). The Nb/Yb ratio of most of the type 1 basalts samples $(\mathrm{Nb} / \mathrm{Yb}=1.1-1.3)$ are higher than average for the $\mathrm{N}-\mathrm{MORB}(\mathrm{Nb} / \mathrm{Yb}=0.76$; Sun 
and McDonough, 1989), which indicates that the mantle source of these basalts is more enriched in $\mathrm{Nb}$ relatively to the $\mathrm{N}-\mathrm{MORB}$, but similar to some back-arc basin basalts (e.g. Pearce et al., 2005; Khanna et al., 2015).

The discriminant diagram $\mathrm{Tb} / \mathrm{Nb} v s . \mathrm{Ce} / \mathrm{Nb}$ (Fig. 11) can be used to test the magmatic source in oceanic basins. In this model, the compositional heterogeneity of basaltic lava flow in oceanic basins is due to the variable mixture of three basic components: (1) a depleted mantle (MORB) with low $\mathrm{Th} / \mathrm{Nb}$ ratio and high $\mathrm{Ce} / \mathrm{Nb}$ ratio; (2) a subduction zone component with high $\mathrm{Th} / \mathrm{Nb}$ and $\mathrm{Ce} / \mathrm{Nb}$ ratios; and (3) a residual plate component. On this diagram, the type 1 basalts of the Serra de Santa Rita greenstone belt plot between the MORB and arc fields, and in the region where the composition of the Phanerozoic Mariana back-arc basin basalts concentrate (Pearce et al., 2005). Thus, the type 1 basalts of the Serra de Santa Rita greenstone belt have chemical characteristics that are similar to modern back-arc basin basalts $(\mathrm{BABB})$ and are here interpreted as tholeiite flows originated by shallow decompression mantle melting related to the opening of a back-arc basin in the Mesoarchean. 


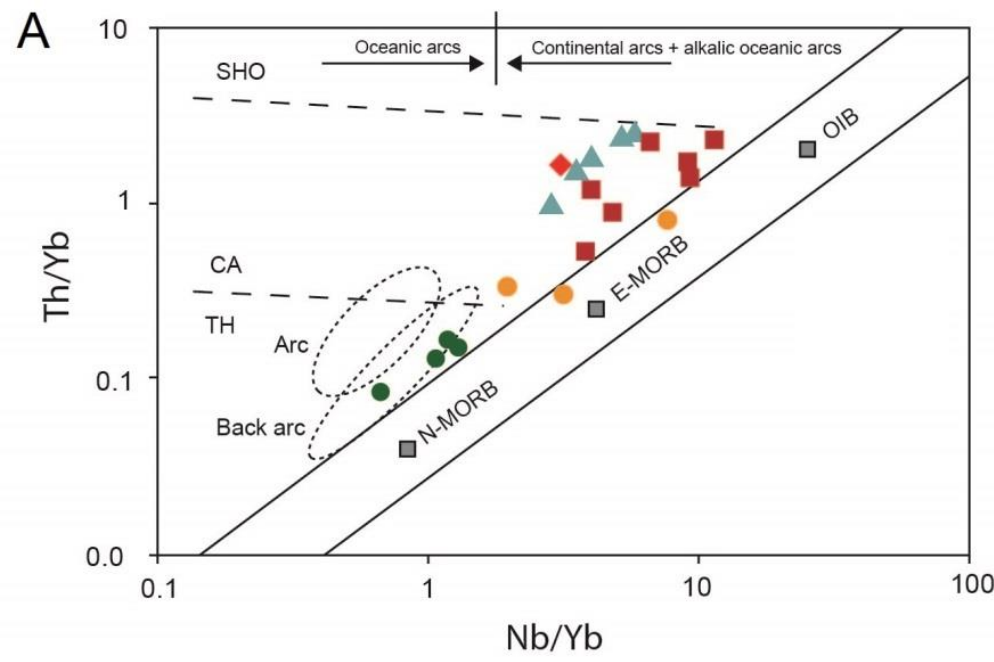

- Amphibolites (Type 1 Basalts)

- Amphibolites (Type 2 Basalts)

A Metandesites

Metadiorites

Metatonalite

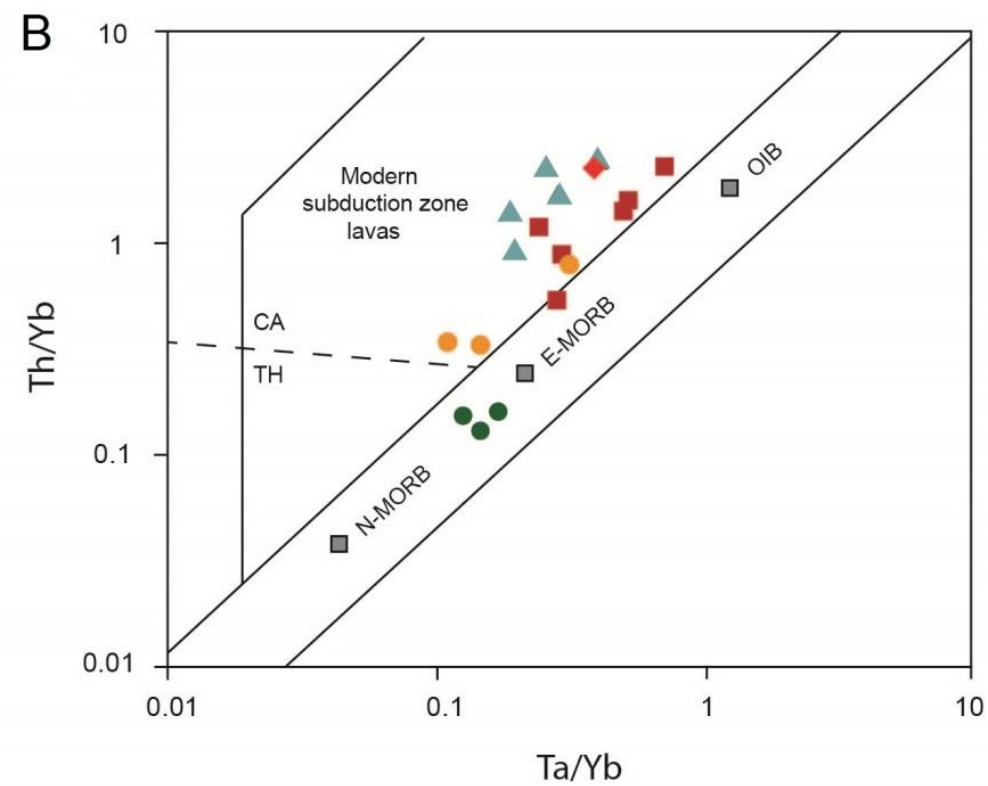

Fig. 10. Tectonic discriminant diagrams for metavolcanic and metaplutonic rocks of the Faina and Serra de Santa Rita greenstone belts. (A) Nb/Yb vs. Th/Yb diagram (Pearce, 2008). Dotted fields represent tholeiitic $(\mathrm{TH})$, calc-alkaline $(\mathrm{CA})$ and shoshonitic $(\mathrm{SHO})$ rocks of convergent margins. Phanerozoic arc and back-arc fields are from Matcalf and Shevais (2008). (B) Ta/Yb vs. Th/Yb diagram (Pearce, 1982, 2003). Dotted fields represent tholeiitic $(\mathrm{TH})$ and calc-alkaline $(\mathrm{CA})$ lavas of modern subduction zones. 


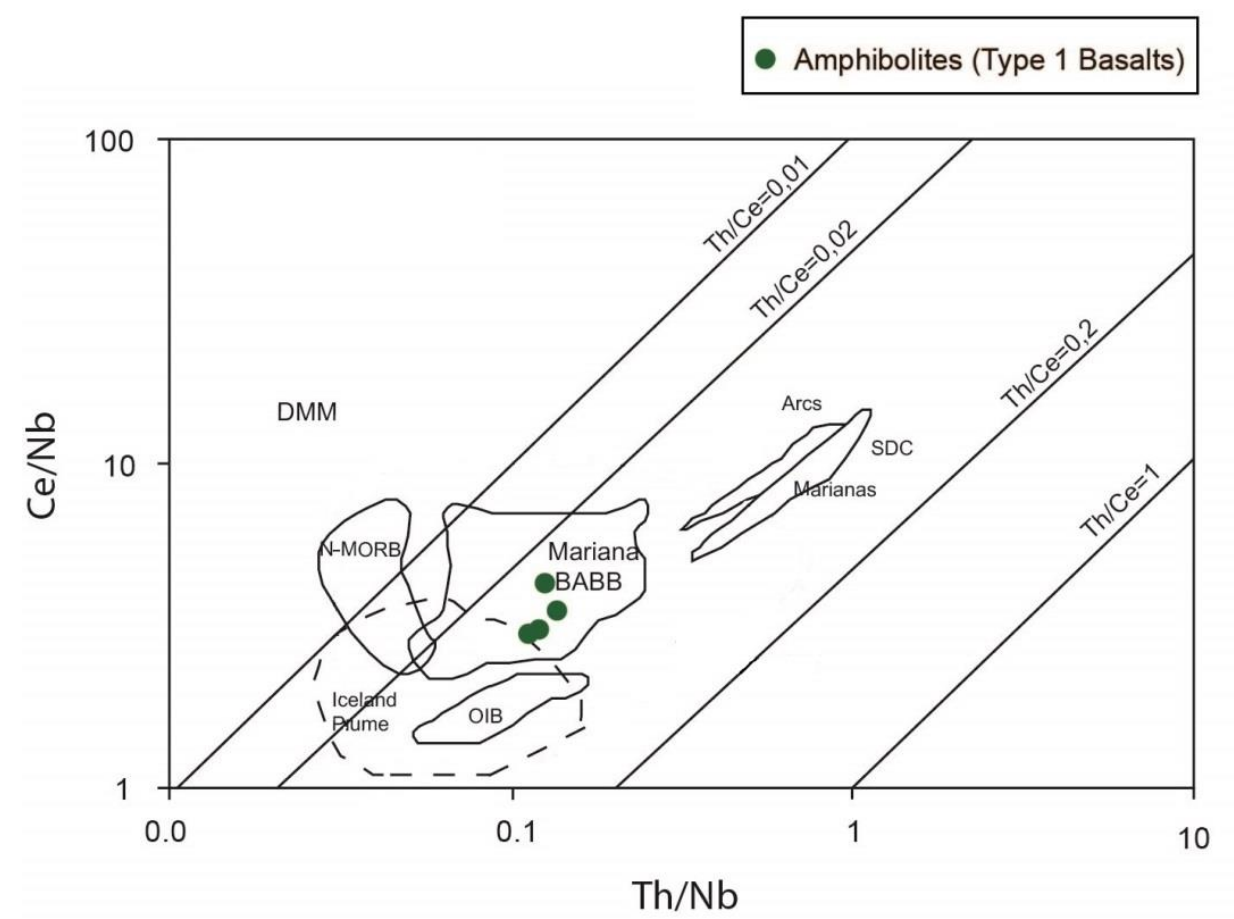

Fig. 11. $\mathrm{Th} / \mathrm{Nb}$ vs. $\mathrm{Ce} / \mathrm{Nb}$ discriminat diagram (modified after Saunders et al., 1988 and Khanna et al., 2015) for amphibolites of the type 1 basalts group of the Serra de Santa Rita greenstone belt; these rocks plot in the Phanerozoic Mariana back-arc basalts field (BABB; Pearce et al., 2005). Abreviations: DMM (depleted MORB mantle component); SDC (subduction zone component).

\subsection{Type 2 basalts: Nb-enriched basalts (NEB)}

The amphibolites corresponding to the type 2 basalts of the Serra de Santa Rita greenstone belt are characterized by sub-alkaline transitional to calc-alkaline magmatic affinity, enriched chondrite-normalized LREE patterns, slightly negative to positive $\mathrm{Nb}$ anomalies, and negative Ti anomalies (Figs. 7C and 7D). The LREE enrichment and negative $\mathrm{Ti}$ and $\mathrm{Nb}$ anomalies are typical features of intraoceanic arc basalts (Perfit et al., 1980; Tatsumi et al., 1986; Tatsumi and Nakamura, 1986; Sauders et al., 1991; Hawkesworth et al., 1993; Pearce and Peate, 1995; Kelemen et al., 2003; Pearce, 2008).

The type 2 basalts are also characterized by high $\mathrm{Nb}$ contents (5.3-12.2 ppm), higher than in typical intraoceanic arc basalts $(\sim 3 \mathrm{ppm})$ and comparable to $\mathrm{Nb}$-enriched basalts (NEB; 7<Nb<20 ppm; Regan and Fill, 1989; Defant et al, 1992). The NEB were first documented in Cenozoic intraoceanic arcs, associated with high-Mg andesites and adakites, characterized by the subduction of young oceanic plate (<20 Ma). Sajona et al. (1996) proposed that the NEB are genetically linked to adakites and were generated by melting of a mantle wedge that had been previously metasomatized by adakitic melt. The adakitic melt 
originated by oceanic slab melting percolates through the mantle wedge and hybridize with it. In this mantle/melt interaction, the original peridotite mineralogy (olivine, orthopyroxene, clinopyroxene and spinel) is destabilized and substituted by new mineral phases, such as pargasitic amphibole, garnet, phlogopite, Na-clinopyroxene and Fe-orthopyroxene (Carroll and Wullie, 1989; Johnston and Wyllie, 1989; Adam et al., 1993; Sen and Dunn, 1994; Kepezhinskas et al., 1995; Rapp et al., 1999; Prouteau et al., 2001). Subsequent melting of this $\mathrm{Nb}$-enriched metasomatized mantle generates the NEB magma.

The Nb-enriched basalts characterized by LREE enrichment and negative to positive $\mathrm{Nb}$ anomalies have been recognized in some Phanerozoic island arc volcanic associations, showing that some volcanic rocks with chemical characteristics similar to ocean island basalts (OIB) can also originate in subduction zones. (Defant et al., 1992; Kepezhinskas et al., 1996; Sajona et al., 1996; Aguillon-Robles et al., 2001; Wang et al., 2007).

$\mathrm{On} \mathrm{Nb} / \mathrm{Yb}$ vs. $\mathrm{Th} / \mathrm{Yb}$ discriminant diagram, two samples of type 2 basalts of the Serra de Santa Rita greenstone belt plot in the MORB-OIB field, next to E-MORB, but almost in the boundary with the subduction-related volcanic rocks field (Fig. 10A). Nonetheless, the Nb contents of these rocks are "anomalous" and cause the higher $\mathrm{Nb} / \mathrm{Yb}$ ratios. Otherwise, on $\mathrm{Ta} / \mathrm{Yb}$ vs. $\mathrm{Th} / \mathrm{Yb}$ discriminant diagram, these rocks all plot outside the MORB-OIB field, consistently with basalts generated in subduction zones (Fig. 10B). On $\mathrm{MgO}$ vs. Nb/La (Fig. $12 \mathrm{~A}$ ) and $\mathrm{Nb} v s . \mathrm{Nb} / \mathrm{U}$ (Fig. 12B) diagrams, the type 2 basalts plot consistently in the NEB field. The exception is the $\mathrm{TiO}_{2}$ vs. $\mathrm{P}_{2} \mathrm{O}_{5}$ diagram, where the samples present lower $\mathrm{TiO}_{2}$ and $\mathrm{P}_{2} \mathrm{O}_{5}$ contents than NEB (Fig. 12C).

In the Serra de Santa Rita greenstone belt, the type 2 basalts are spatially associated with the metandesites and metadiorites that have clear geochemical affinity with magmatic arcs, as enhanced by the $\mathrm{Nb} / \mathrm{Yb}$ vs. $\mathrm{Th} / \mathrm{Yb}$ (Fig. 10A) and $\mathrm{Ta} / \mathrm{Yb}$ vs. Th/Yb (Fig. 10B) discriminant diagrams. The metandesites and metadiorites also present some similarities with adakites and high-Mg andesites (HMA), respectively, as will be discussed latter. Thus, these rocks must represent an association between NEB, HMA and adakites. This association has also been recognized in several Archean greenstone belts (Hollings and Kerrich, 2000; Wyman et al., 2000; Polat and Kerrich, 2001; Hollings, 2002; Shchipansky et al., 2004; Manikyamba and Khanna, 2007; Manikyamba et al., 2007; Kerrich and Manikyamba, 2012), in which petrogenesis has been interpreted as analogous to the modern equivalents, therefore being extremely important for the understanding of the Archean geodynamic. 


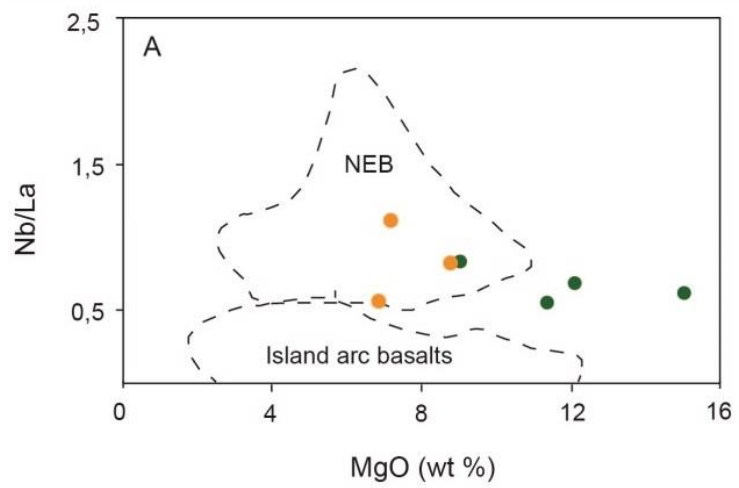

- Amphibolites (Type 1 basalts)

- Amphibolites (Type 2 basalts)
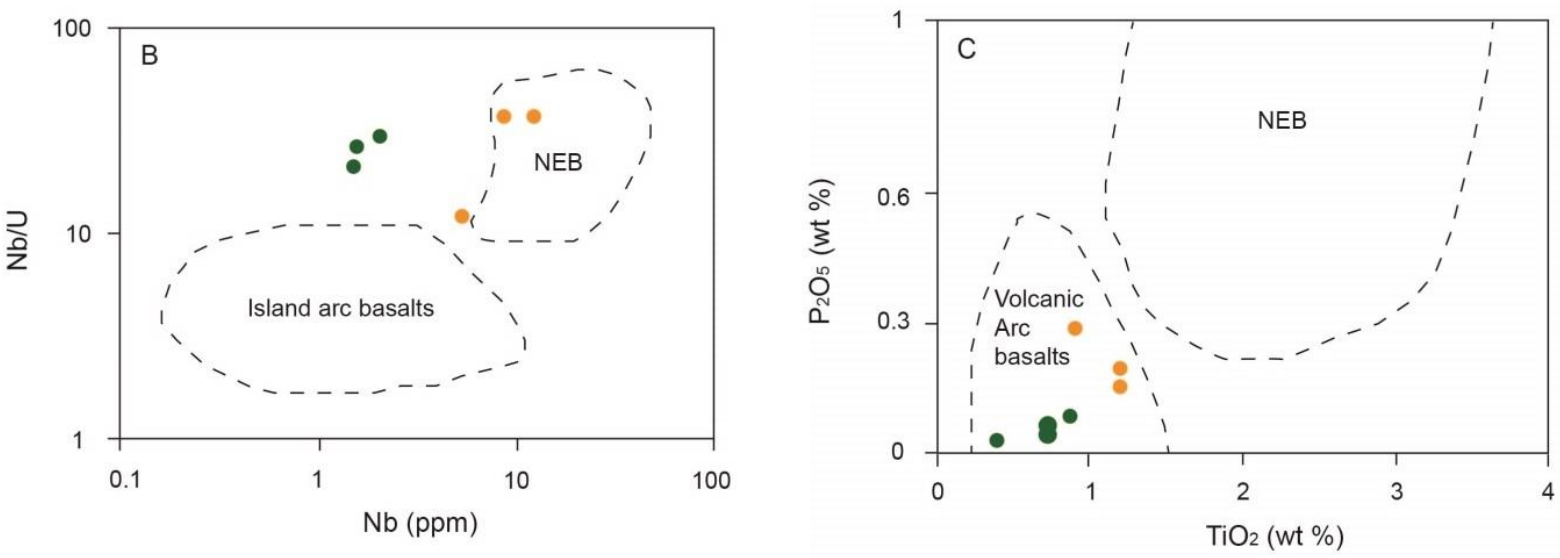

Fig. 12. Discriminant diagrams distinguishing Nb-enriched basalts (NEB) from classical volcanic arc basalts for the amphibolites of the Serra de Santa Rita greenstone belt. (A) Nb vs. Nb/U diagram (Kepezhinskas et al., 1996). (B) $\mathrm{MgO}$ vs. Nb/La diagram (Kepezhinskas et al., 1996). (C) $\mathrm{TiO}_{2}$ vs. $\mathrm{P}_{2} \mathrm{O}_{5}$ diagram (Defant et al., 1992). The amphibolites of the type 2 basalts group plot in the NEB field on $\mathrm{MgO} v s$. $\mathrm{Nb} / \mathrm{La}$ and $\mathrm{Nb} v s$. $\mathrm{Nb} / \mathrm{U}$ diagrams, while on $\mathrm{TiO}_{2}$ vs. $\mathrm{P}_{2} \mathrm{O}_{5}$ diagram, these rocks plot outside. The amphibolites of the type 1 basalts group plot outside the NEB field on all diagrams.

7.6. Correlations between the metandesites, metadiorites and metatonalies with adakites and high-Mg andesites

As originally defined by Defant and Drummond (1990), adakites are a suite of intermediate to felsic rocks with $\mathrm{SiO}_{2} \geq 56$ wt.\%, $\mathrm{Al}_{2} \mathrm{O}_{3} \geq 15$ wt.\%, high $\mathrm{Na}_{2} \mathrm{O}$ contents $\left(\mathrm{Na}_{2} \mathrm{O}=3.5-7.5\right.$ wt. \%), low $\mathrm{K}_{2} \mathrm{O} / \mathrm{Na}_{2} \mathrm{O}$ ratio ( $\left.~ 0.42\right), \mathrm{MgO}$ usually $<3$ wt. $\%$ and high contents of $\mathrm{Sr}(\geq 400 \mathrm{ppm})$. Adakites are also characterized by strongly fractionated REE patterns $\left(\mathrm{La} / \mathrm{Yb}_{\mathrm{cn}}>10\right)$ and low contents of $\mathrm{Y} \leq 18 \mathrm{ppm}$ and $\mathrm{Yb} \leq 1.9 \mathrm{ppm}$. They were initially introduced as Na-rich volcanic and plutonic rocks formed in Cenozoic magmatic arcs associated with subduction of young ( $\leq 25 \mathrm{Ma}$ ) and hot oceanic lithosphere. Based on $\mathrm{SiO}_{2}$ and $\mathrm{MgO}$ contents, Martin et al. (2005) divided the adakites into two broad groups: the high-silica adakites (HSA; $\mathrm{SiO}_{2}>60$ wt. $\%, \mathrm{MgO} \leq 4$ wt. $\%$ and $\# \mathrm{Mg} \leq 50$ ) and the low silica-adakites (LSA; also reffered as 
high- $\mathrm{Mg}$ andesites; $\mathrm{SiO}_{2}<60$ wt. $\%, \mathrm{MgO}=4-9$ wt. $\%$ and $\left.\# \mathrm{Mg} \geq 60\right)$. The LSA are also characterized by higher Sr contents $(>1000$ ppm) than HSA $(<1100$ ppm).

The metandesites of the Serra de Santa Rita greenstone belt have fractionated REE patterns $\left(\mathrm{La} / \mathrm{Yb}_{\mathrm{cn}}=7-15\right)$ and low contents of $\mathrm{Yb}$ (1.2-1.6 ppm) and $\mathrm{Y}$ (14-15). The only exception is one metandesite sample (D26) that exhibits values of $\mathrm{La} / \mathrm{Yb}_{\mathrm{cn}}, \mathrm{Yb}$ and $\mathrm{Y}(5,2.5$ and $27 \mathrm{ppm}$, respectively) contrasting from the other samples. The metadiorites and the analyzed metatonalite sample have higher REE fractionated patterns $(\mathrm{La} / \mathrm{Yb}=8-19)$ and lower contents of $\mathrm{Yb}(0.7-1.2 \mathrm{ppm})$ and $\mathrm{Y}(8-17 \mathrm{ppm})$ than the metandesites. On Sr/Y vs. Y (Fig. $13 \mathrm{~A})$ and $(\mathrm{La} / \mathrm{Yb})_{\mathrm{cn}}$ vs. $\mathrm{Yb}_{\mathrm{cn}}$ (Fig. 13B) discriminant diagrams, most of the metandesites, metadiorites and metatonalite samples plot in the adakite field.

The above characteristics show that the metandesites, metadiorites and metatonalites of the Serra de Santa Rita greenstone belt present some of the typical diagnostic features of adakites. However, it is important to point out that adakites are characterized by high $\mathrm{Sr}$ contents and related high $\mathrm{Sr} / \mathrm{Y}$ ratio $(>50)$, what is not observed in the metandesites and metadiorites, in which $\mathrm{Sr} / \mathrm{Y}$ ratios are lower and quite variable (12-44 for the metandesites and 5-38 ppm for the metadiorites) than those of adakites. The metatonalite sample, otherwise, have very high $\mathrm{Sr} / \mathrm{Y}$ ratio (114), consistent with adakites. Adakitic magmas with high Sr contents are produced by partial melting of Sr-rich eclogite in a descending slab (as there is no plagioclase in the restite). Fractional crystallization of these magmas at shallower dephts could reduce the Sr contents by plagioclase removal (Kamber et al., 2002; Samaniego et al., 2002). Thus, the metandesites, metadiorites and metatonalites of the Serra de Santa Rita greenstone belt are adakite-like rocks that were affected by different degrees of fractional crystallization processes.

The metandesites are characterized by relative high contents of $\mathrm{MgO}$ (2-6 wt.\%) and \#Mg (51-61), values near to those of LSA, otherwise, their $\mathrm{SiO}_{2}$ contents (56-68 wt.\%) show that some of the samples are more consistent with HSA. The metatonalite sample have lower contents of $\mathrm{MgO}$ (2 wt.\%) and \#Mg (42), and higher contents of $\mathrm{SiO}_{2}$ (66 wt.\%), also consistent with $\mathrm{HSA}$. On $\mathrm{SiO}_{2}$ vs. $\mathrm{MgO}$ and $\mathrm{SiO}_{2} v s$. $\mathrm{Nb}$ diagrams, most of the metandesite samples and the metatonalite sample plot in the HSA field (Figs. 13C and 13D), and some of the metandesite samples plot in the LSA field on $\mathrm{SiO}_{2}$ vs. $\mathrm{MgO}$ diagram (Fig. 13C). The metadiorites are characterized by very high contents of $\mathrm{MgO}(9-15 \%)$ and $\# \mathrm{Mg}(70-81)$, and low contents of $\mathrm{SiO}_{2}$ (54-58 wt.\%), being comparable to LSA. All metadiorite samples plot in 
the LSA field on $\mathrm{SiO}_{2} v s$. Nb diagram (Fig. 13D), and extrapolate the LSA field on $\mathrm{SiO}_{2} v s$. $\mathrm{MgO}$ diagram due to their extremely high $\mathrm{MgO}$ contents (Fig. 13C).

Although modern adakites occur in subduction zones that show unusually high heatflow, which is the case of young oceanic slab subduction, several other mechanisms have also been proposed to account the origin of specific adakite-like rocks in different tectonic settings. Some of these mechanisms include: crustal assimilation and fractional crystallyzation from basaltic magmas (e.g. Castillo et al., 1999); partial melting of hydrated mafic rocks in the base of thickened crust (e.g. Atherton and Petford, 1993; Condie, 2005); and partial melting of delaminated lower crust (Gao et al., 2004; Wang et al., 2006). However, apparently there is no evidence of any older continental crust contamination in the metandesites and metadiorites of the Faina and Serra de Santa Rita greenstone belts. Moreover, the adakites which are generated from crustal melting processes have relatively high $\mathrm{K}$ and Th contents $\left(\mathrm{K}_{2} \mathrm{O} \sim 3 \mathrm{wt} / \%\right.$ and $\left.\mathrm{Th}=10-20 \mathrm{ppm}\right)$, due to the greater involvement with felsic crustal material (Condie, 2005), what is clearly not the case of the metandesites, metadiorites and metatonalites of the Serra de Santa Rita greenstone belt $\left(\mathrm{K}_{2} \mathrm{O}=0.1-1.4\right.$ wt.\%; $\mathrm{Th}=0.4-3.2 \mathrm{ppm})$. Thus, these rocks were probably not derived from melting processes of lower thickened crust; and it is more likely that they were produced by partial melting of subducting oceanic slab.

In this context, the difference between HSA and LSA is not simply a subtle difference in chemistry or an artefact of classification. Rather, it reflects a fundamental difference in petrogenesis, and specifically in different sources (Martin et al., 2005). The HSA are generated by direct melting of subducted oceanic crust transformed into garnet-bearing amphibolite or eclogite (Defant and Drummond, 1990; Martin, 1999; Gutcher et al., 2000; Martin et al., 2005). Those slab-melts are variably contaminated by peridotite assimilation as they ascend through the mantle wedge (Martin et al., 2005). The LSA (or high-Mg andesites; HMA) are generated in two distinct episodes; complete consumption of slab-melt during melt-peridotite interaction, followed by melting of this metasomatized mantle source (Rapp et al., 1999; Martin et al., 2005). The unifying petrogenetic feature of the HSA and LSA magmas is that both are directly or indirectly linked to slab-melts (Martin et al., 2005).

The adakitic melt not only assimilates the peridotite during its ascent, but also hybridize with the mantle wedge, being progressively consumed. When the melt/rock (adakitic melt/peridotite) is high, not all adakitic melt is consumed during the mantle 
metasomatism, and the melt can erupt as adakitic lavas. When the melt/rock is low, all adakitic melt is consumed in the metasomatic reaction with the mantle. Melting of this metasomatized mantle also produces magma that preserves strong adakite-like signatures (Rapp et al., 1999).

The metandesites and metatonalites of the Serra de Santa Rita greenstone belt have more similarities with HSA and, attributing a similar petrogenesis, these rocks may represent melting of subducting oceanic slab that variably interacted with the mantle during its ascent, what explains the $\mathrm{MgO}, \mathrm{Cr}$ and $\mathrm{Ni}$ enrichment in the metandesites. The metadiorites are more similar to LSA or high-Mg andesites, although these rocks have lower $\mathrm{Sr}$ (167-616 ppm) than the common high $\mathrm{Sr}$ contents of LSA (>1000 ppm). The high contents of $\mathrm{MgO}, \mathrm{Cr}$ and $\mathrm{Ni}$ of the metadiorites indicate presumably that these magmas were in equilibrium with the peridotite mantle (Tatsumi and Ishizaka, 1982; Yogodzinski et al., 1994). The origin of these magmas is interpreted as melting of mantle wedge that was previously metasomatized by adakitic melt, similar to the petrogenesis assigned to LSA. 

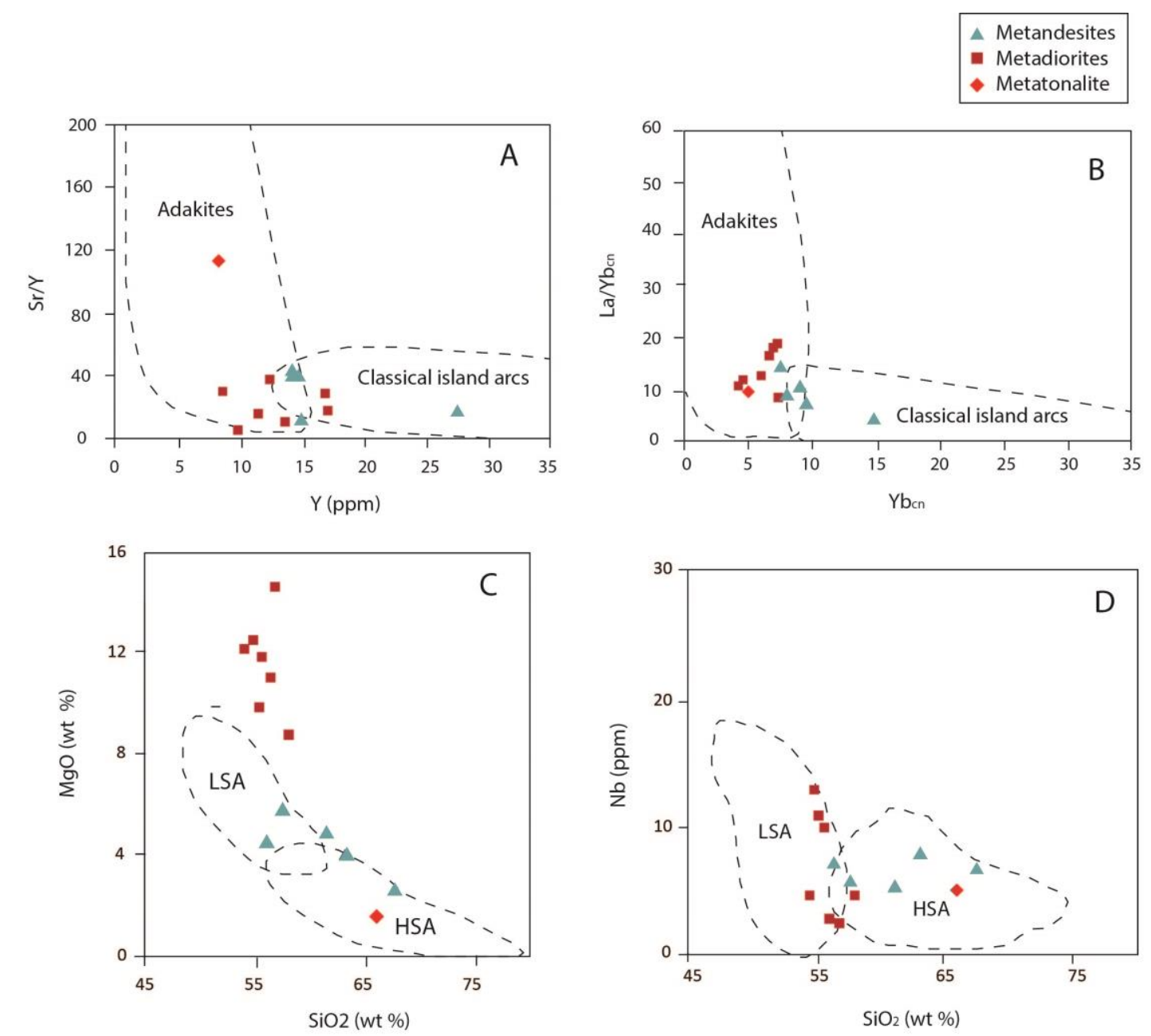

Fig. 13. Discriminant diagrams distinguishing adakites from classical island arc volcanic rocks (A-B) and high$\mathrm{SiO}_{2}$ adakites from low-SiO${ }_{2}$ adakites (C-D) for the metandesites, metadiorites and metatonalites of the Serra de Santa Rita greenstone belt. (A) Y vs. Sr/Y diagram (Defant and Drummond, 1990). (B) $\mathrm{Y}_{\mathrm{cn}} v s . \mathrm{La} / \mathrm{Yb}_{\mathrm{cn}}$ diagram (Martin, 1987, 1999). (C) $\mathrm{SiO}_{2}$ vs $\mathrm{MgO}$ diagram (Martin et al., 2005). (D) $\mathrm{SiO}_{2}$ vs $\mathrm{Nb}$ diagram (Martin et al., 2005). The rocks plot predominantly in the adakite fields on $\mathrm{Y} v s . \mathrm{Sr} / \mathrm{Y}$ and $\mathrm{Y}_{\mathrm{cn}} v s . \mathrm{La} / \mathrm{Yb}_{\mathrm{cn}}$ diagrams. The metandesites and metatonalite plot predominantly in the HAS fields on $\mathrm{SiO}_{2} v s \mathrm{MgO}$ and $\mathrm{SiO}_{2}$ vs $\mathrm{Nb}$ diagrams, while the metadiorites plot in the $\mathrm{LSA}$ field on $\mathrm{SiO}_{2}$ vs $\mathrm{Nb}$ diagram and extrapolates the LSA field on $\mathrm{SiO}_{2} v s$ $\mathrm{MgO}$ diagram due to their very high $\mathrm{MgO}$ contents.

\section{Geodynamic setting}

Discussions of the presented data indicate that the protoliths of the metavolcanic and metaplutonic rocks of the Faina and Serra de Santa Rita greenstone belts are related to subduction zones. The komatiites, basalts, andesites and diorites constitute a Mesoarchean intraoceanic forearc-arc-back-arc assembly, formed between 2.96 and $2.92 \mathrm{Ga}$. These ages were obtained by $\mathrm{U}-\mathrm{Pb}$ zircon dating of the amphibolite (type 2 basalts group) and metadiorite samples, respectively, and for the chloritite samples whose protoliths are probably the high- 
$\mathrm{Mg}$ diorites but can also be mafic rocks like the amphibolites (type 2 basalts group). Positive and homogeneous values of initial $\varepsilon_{\mathrm{N} d}(2.18-2.77)$ suggest that these rocks were derived from a juvenile arc. The system later progressed to a continental arc setting with tonalitic magmatism at around $2.79 \mathrm{Ga}$. This age was obtained by U-Pb zircon dating of the metatonalite sample that presented initial $\varepsilon_{\mathrm{Nd}}$ of -0.30 , indicating a crustal contribution to this magmatism.

Therefore, the evolution model of the Faina and Serra de Santa Rita greenstone belts' igneous protholiths proposed in this study is synthetized into four main stages:

1. The initial stage concerns to ultramafic volcanism in a forearc setting under shallow hydrous high melting degrees of the refractory mantle in the early stages of an island arc formation, at around $2.96 \mathrm{Ga}$ (Fig. 14A);

2. The subduction progression led to subducting slab melting and adakite production. The adakitic melt hybridized with the peridotite mantle during its ascent and the high melt/rock ratio allowed the magma to reach the surface as adakitic lavas that now are represented by the metandesites of the Serra de Santa Rita greenstone belt. Melting of the residual mantle that was previously metasomatized by adakitic melt led to $\mathrm{Nb}$-enriched basalts formation, that now are represented by the amphibolites of the type 2 basalts group of the Serra de Santa Rita greenstone belt. Decompression mantle melting in the back-arc region led to the generation of tholeiitic basalt flows that now are represented by the amphibolites of the type 1 basalts group of the Serra de Santa Rita greenstone belt (Fig. 14B);

3. The low melt/rock ratio, at around $2.92 \mathrm{Ga}$, led to the consumption of all adakitic melt by the peridotite mantle in the metasomatic reaction. Melting of this hybridized mantle, that preserves the chemical imprint of the slab-melt, generated high-Mg andesitic magma with very high contents of $\mathrm{MgO}, \mathrm{Cr}$ and $\mathrm{Ni}$, comparable to low-SiO${ }_{2}$ adakites or high- $\mathrm{Mg}$ andesites. The magma did not reach the surface as new andesitic lava flows, and lodged as dioritic plutons that intruded the volcanic sequences (Fig. 14C);

4. The final stage, at around $2.79 \mathrm{Ga}$, is related to the generation of tonalitic magma in a continental arc setting in the late Mesoarchean and early Neoarchean. This stage corresponds to the initial agglutination and cratonization of the Archean substrate of the southern portion of the Archean-Paleoproterozoic Terrane of Goiás and is also registered in the Caiçara and 
Uvá complexes by TTG magmatism with ages at around $2.8 \mathrm{Ga}$ (Jost et al., 2005, 2013; Beghelli Junior, 2012) (Fig. 14D).
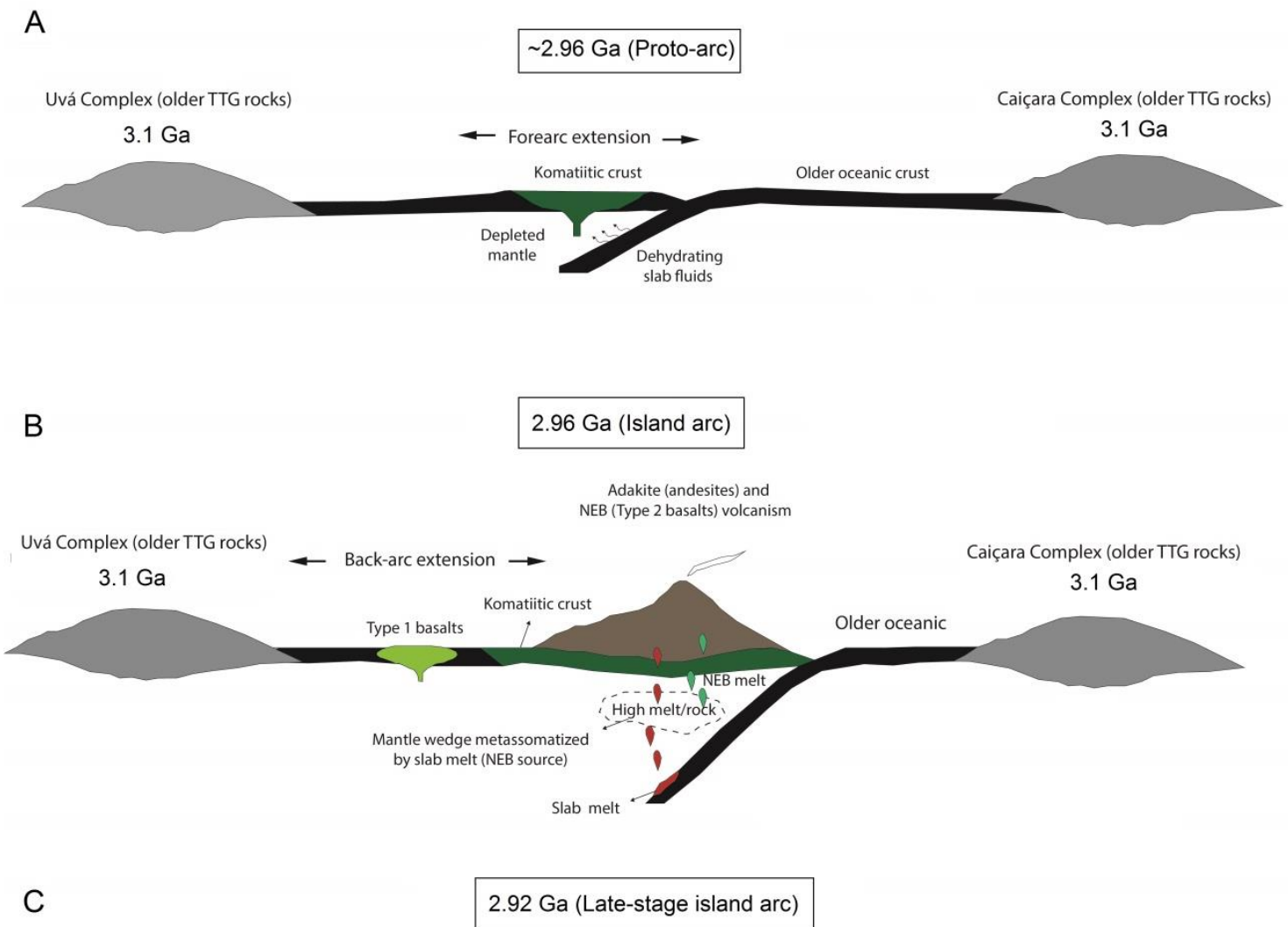

Uvá Complex (older TTG rocks)
$3.1 \mathrm{Ga}$
Adakite (andesites) and
NEB (Type 2 basalts) High-Mg diorites
Caiçara Complex (older TTG rocks)
$3.1 \mathrm{Ga}$
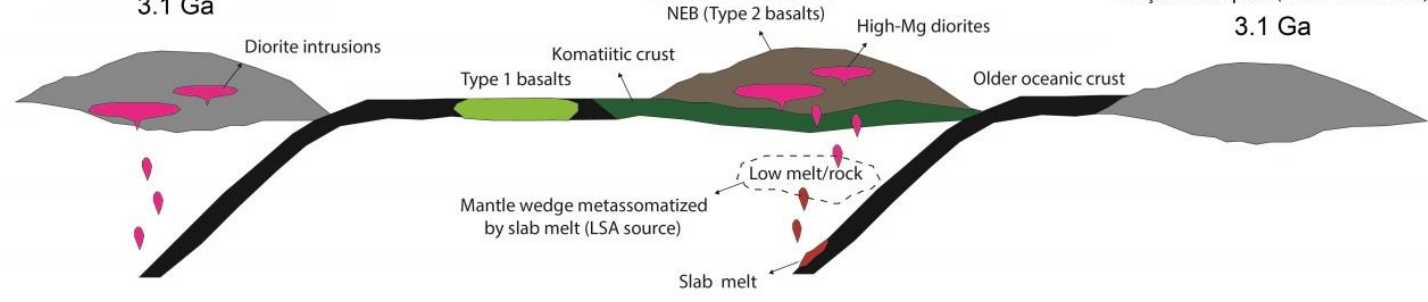

$\mathrm{D}$

\section{$2.79 \mathrm{Ga}$ (Continental arc)}

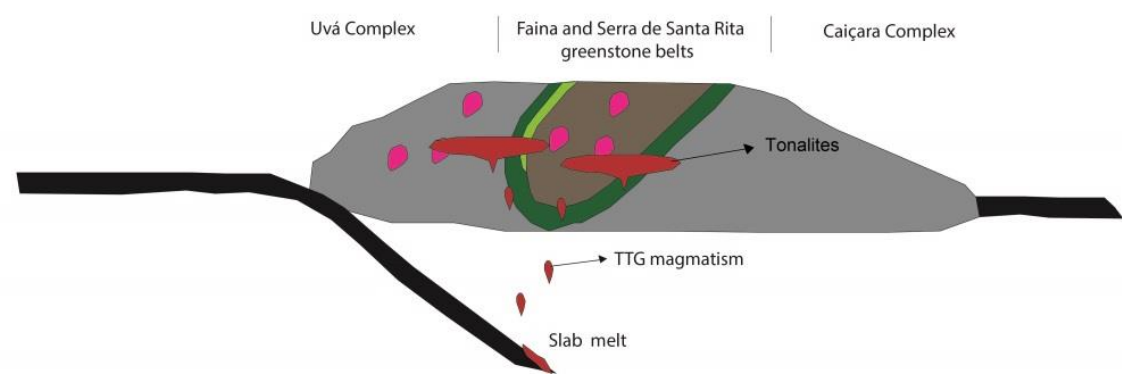

Fig. 14. Geodynamic setting evolution stages proposed for the Faina and Serra de Santa Rita greenstone belts. The volcanic and plutonic rocks are inserted into an island arc evolution at 2.96-2.92 Ga and continental arc at $2.79 \mathrm{Ga}$. The Uvá and Caiçara complexes are represented by their oldest TTG rocks ( 3.1 Ga). 


\section{Conclusions}

The petrographic, geochemical and isotopic studies of the metavolcanic and metaplutonic rocks of the Faina and Serra de Santa Rita greenstone belts presented in this study allowed the following conclusions:

1. The basal metavolcanic sequences of the Faina and Serra de Santa Rita greenstone belts are composed mainly of ultramafic rocks. The mafic rocks correspond to amphibolites restricted to the Serra de Santa Rita greenstone belt and are associated with metandesite lenses and dioritic to tonalitic poly-deformed intrusions. These rocks were metamorphosed under amphibolite facies and are overlain by Paleoproterozoic metasedimentary sequences metamorphosed under greenschist facies;

2. The geochemical signatures of the ultramafic rocks have some similarities with boninites. The amphibolites can be divided into two groups based on their trace-elements: type 1 basalts and type 2 basalts. The type 1 basalts are similar to back-arc basin basalts, while the type 2 basalts are similar to $\mathrm{Nb}$-enriched basalts. The metandesites, metadiorites and metatonalites are adakite-like rocks; the metandesites and metatonalites have some similarities with highsilica adakites, while the metadiorites are characterized by very high $\mathrm{MgO}, \mathrm{Cr}$ and $\mathrm{Ni}$ contents and are similar to low-silica adakites or high-Mg andesites. The association between adakites, high-Mg andesites and $\mathrm{Nb}$-enriched basalts occur in some hot Cenozoic subduction zones and is also described in several Archean greenstone belts;

3. The chloritites are spatially associated to the ultramafic schist and cumulate-textured rocks but they have very different geochemical signatures from them. On the other hand, the traceelements features of the chloritites are similar to the metadiorites and less likely to the amphibolites of the type 2 basalts group. Thus, these rocks are probably a result of hydrothermalism on the high-Mg dioritic rocks, but can also derivate from the mafic rocks;

4. LA-ICP-MS U-Pb zircon dating were conducted in five samples: a chloritite from the Faina greenstone belt, a chloritite from the Serra de Santa Rita greenstone belt, an amphibolite of the type 2 basalts group, a metadiorite and a metatonalite. With the exception of the chloritite of the Serra de Santa Rita greenstone belt sample, the zircon crystals data of all dated samples provided discordia diagrams and ages defined by upper intercepts. The chloritite sample from the Faina greenstone belt yielded the age of $2921 \pm 64$ Ma. The chloritite sample from the Serra de Santa Rita greenstone belt yielded the concordant age of 2960.3 \pm 5.5 Ma. The 
amphibolite sample yielded the age of $2959.5 \pm 6.1$ Ma. The metadiorite sample yielded the age of $2922.8 \pm 2.8 \mathrm{Ma}$. The metatonalite sample yielded the age of $2794 \pm 14 \mathrm{Ma}$. These results are interpreted as the best approximations of the protoliths' crystallization ages and mark two main periods of igneous activity: $2.96-2.92 \mathrm{Ga}$ and $2.79 \mathrm{Ga}$;

5. Isotopic Sm-Nd analyses were carried out in four samples: an amphibolite of the type 2 basalts group, two metadiorites and a metatonalite. The amphibolite presented $\mathrm{T}_{\mathrm{DM}}$ of $3.08 \mathrm{Ga}$ and initial $\varepsilon N d$ of 2.18. The metadiorites presented $\mathrm{T}_{\mathrm{DM}}$ of 3.03 and $2.99 \mathrm{Ga}$, and initial $\varepsilon \mathrm{Nd}$ of 2.16 and 2.77. These data indicate juvenile magmatic signatures and absence of older sialic crust contamination for the rocks crystallized in the first period $(2.96-2.92 \mathrm{Ga})$. The metatonalite sample crystallized at $2.79 \mathrm{Ga}$ shows $\mathrm{T}_{\mathrm{DM}}$ of $3.13 \mathrm{Ga}$ and initial ${ }_{\mathrm{ENd}}$ of -0.30 , indicanting crustal contribution in this second period;

6. The geodynamic model of the volcanic and plutonic protoliths that constitute the Faina and Serra de Santa Rita greenstone belts is inserted into an intraoceanic forearc-arc-back-arc setting. The initial stage corresponds to eruption of ultramafic lavas in the forearc region of a proto-island arc, at around $2.96 \mathrm{Ga}$. The evolution of the island arc and subduction progression led to oceanic slab-melting and generation of adakites (metandesites of the Serra de Santa Rita greenstone belt). Melting of the enriched residual mantle that was metasomatized with adakitic melt generated $\mathrm{Nb}$-enriched basalts (amphibolites of the type 2 basalts group of the Serra de Santa Rita greenstone belt). Decompression mantle melting at the back-arc region generated tholeiitic basaltic flows (amphibolites of the type 1 basalts group of the Serra de Santa Rita greenstone belt). At around 2.92, the adakitic melt was totally consumed by peridotite mantle and the subsequent melting of these hybridized mantle wedge generated high-Mg andesites that lodged in the crust as dioritic intrusions with high contents of $\mathrm{MgO}, \mathrm{Cr}$ and $\mathrm{Ni}$ (metadiorites of the Serra de Santa Rita greenstone belt). The late stage corresponds to a continental arc formation at around $2.79 \mathrm{Ga}$, marked by tonalitic magmatism and amalgamation with other island arcs and continental arcs that constitute the TTG Uvá and Caiçara complexes to form the Archean substrate of the southern portion of the ArcheanPaleoproterozoic Terrane of Goiás. 


\section{Appendix}

10.1. Coordinates of the samples used in this study.

Table 1. Coordinates of the samples of metavolcanic and metaplutonic rocks of the Faina and Serra de Santa Rita greenstone belts that were used for microprobe analyses, whole rock geochemistry and isotopic studies. Datum: WGS 84/UTM zone 22S.

\begin{tabular}{|c|c|c|c|c|}
\hline Sample & Rock type & Location & $\mathbf{E}$ & $\mathbf{N}$ \\
\hline TF14-000 & Pillowed komatiite & Serra de Santa Rita greenstone belt & 595604 & 8242442 \\
\hline TF14-I-003 & Ultrumafic cumulate & Faina greenstone belt & 550838 & 8301340 \\
\hline TF14-I-004A & Ultrumafic cumulate & Faina greenstone belt & 550624 & 8301244 \\
\hline TF14-I-075B & Ultramafic schist & Faina greenstone belt & 550113 & 8301266 \\
\hline TF14-I-098A & Ultramafic schist & Faina greenstone belt & 543998 & 8304892 \\
\hline TF14-I-099 & Chloritite & Faina greenstone belt & 544033 & 8304924 \\
\hline TF14-II-125A & Ultramafic schist & Faina greenstone belt & 574611 & 8255516 \\
\hline TF14-V-133 & Ultramafic schist & Faina greenstone belt & 563256 & 8287986 \\
\hline TF14-VII-012B & Chloritite & Faina greenstone belt & 563806 & 8279585 \\
\hline TF14-XI-016 & Chloritite & Serra de Santa Rita greenstone belt & 568539 & 8260278 \\
\hline TF14-XII-079B & Mafic schist & Serra de Santa Rita greenstone belt & 569280 & 8260068 \\
\hline TF14-XII-015A & Mylonitized diorite & Serra de Santa Rita greenstone belt & 574116 & 8252818 \\
\hline TF14-XII-015B & Amphibolite & Serra de Santa Rita greenstone belt & 574116 & 8252818 \\
\hline TF14-XII-093 & Ultramafic schist & Serra de Santa Rita greenstone belt & 568419 & 8253089 \\
\hline TF14-XII-167 & Ultramafic schist & Serra de Santa Rita greenstone belt & 577167 & 8252313 \\
\hline TF14-XII-178 & Amphibolite & Serra de Santa Rita greenstone belt & 574505 & 8252410 \\
\hline TF14-XII-183 & Metatonalite & Serra de Santa Rita greenstone belt & 572842 & 8253857 \\
\hline PFG-CA-004A & Metadiorite & Serra de Santa Rita greenstone belt & 572842 & 8253857 \\
\hline PFG-CA-004B & Metadiorite & Serra de Santa Rita greenstone belt & 573802 & 8252860 \\
\hline PFG-CA-004D & Metadiorite & Serra de Santa Rita greenstone belt & 573802 & 8252860 \\
\hline PFG-CA-004E & Metadiorite & Serra de Santa Rita greenstone belt & 573802 & 8252860 \\
\hline PFG-CA-004G & Metadiorite & Serra de Santa Rita greenstone belt & 573802 & 8252860 \\
\hline PFG-CA-016A & Amphibolite & Serra de Santa Rita greenstone belt & 574121 & 8252906 \\
\hline
\end{tabular}


Table 1. (Continued).

\begin{tabular}{|c|c|c|c|}
\hline Sample & Rock type & Location & E \\
\hline PFG-CA-016B & Mylonitized diorite & Serra de Santa Rita greenstone belt & 574121 \\
\hline PFG-CA-017A & Amphibolite & Serra de Santa Rita greenstone belt & 573838 \\
\hline PFG-CA-019A & Amphibolite & Serra de Santa Rita greenstone belt & 573757 \\
\hline PFG-CA-019B & Amphibolite & Serra de Santa Rita greenstone belt & 573757 \\
\hline PFG-CA-030 & Metandesite & Serra de Santa Rita greenstone belt & 596209 \\
\hline D22 & Serra de Santa Rita greenstone belt & 8253571 \\
\hline D23 & Metandesite (Drill hole sample) & Serra de Santa Rita greenstone belt & 596209 \\
\hline D24 & Metandesite (Drill hole sample) & Serra de Santa Rita greenstone belt & 596209 \\
\hline D26 & Metandesite (Drill hole sample) & Serra de Santa Rita greenstone belt & 5253538 \\
\hline
\end{tabular}




\subsection{Summary of electron microprobe analyses data}

Table 2.1. Amphibole composition data obtained from eletron microprobe analyses (wt. \%).

\begin{tabular}{|c|c|c|c|c|c|c|c|c|c|}
\hline \multirow{3}{*}{$\begin{array}{l}\text { Samples } \\
\text { Analyses } \\
\text { (Mineral) }\end{array}$} & \multicolumn{9}{|c|}{ Ultramafic rocks } \\
\hline & \multicolumn{3}{|c|}{ TF14-I-098A } & \multicolumn{6}{|c|}{ TF14-I-003 } \\
\hline & $\begin{array}{c}1 \\
\text { (Tremolite) }\end{array}$ & $\begin{array}{c}2 \\
\text { (Tremolite) }\end{array}$ & $\begin{array}{c}3 \\
\text { (Tremolite) }\end{array}$ & $\begin{array}{c}1 \text { (Mg- } \\
\text { hornblende) }\end{array}$ & $\begin{array}{c}2 \text { (Mg- } \\
\text { hornblende) }\end{array}$ & $\begin{array}{c}3 \text { (Mg- } \\
\text { hornblende) }\end{array}$ & $\begin{array}{c}4 \text { (Mg- } \\
\text { hornblende) }\end{array}$ & $\begin{array}{c}5 \\
\text { (Tremolite) }\end{array}$ & $\begin{array}{c}6(\mathrm{Mg}- \\
\text { hornblende) }\end{array}$ \\
\hline $\mathrm{SiO}_{2}$ & 57.567 & 57.06 & 57.617 & 49.116 & 46.002 & 47.523 & 46.963 & 57.312 & 48.156 \\
\hline $\mathrm{TiO}_{2}$ & 0.189 & - & - & 0.804 & 0.354 & 0.197 & 0.248 & 0.045 & 1.898 \\
\hline $\mathrm{Al}_{2} \mathrm{O}_{3}$ & 0.147 & 0.141 & 0.118 & 6.292 & 9.786 & 8.655 & 8.755 & 0.794 & 6.51 \\
\hline $\mathrm{FeO}$ & 5.352 & 5.575 & 5.163 & 8.436 & 9.886 & 9.42 & 10.196 & 5.277 & 8.114 \\
\hline $\mathrm{MnO}$ & 0.236 & 0.204 & 0.237 & 0.364 & 0.318 & 0.179 & 0.362 & 0.095 & 0.337 \\
\hline $\mathrm{MgO}$ & 21.773 & 21.83 & 21.857 & 16.303 & 15.521 & 15.88 & 15.414 & 20.739 & 17.379 \\
\hline $\mathrm{CaO}$ & 12.203 & 12.453 & 12.593 & 12.229 & 11.534 & 12.065 & 12.211 & 12.418 & 11.04 \\
\hline $\mathrm{Na}_{2} \mathrm{O}$ & 0.213 & 0.186 & 0.174 & 1.05 & 2.117 & 1.805 & 1.821 & 0.158 & 0.662 \\
\hline $\mathrm{K}_{2} \mathrm{O}$ & 0.015 & 0.013 & 0.029 & 0.31 & 0.226 & 0.154 & 0.185 & 0.002 & 0.203 \\
\hline $\mathrm{Cr}_{2} \mathrm{O}_{3}$ & 0.022 & - & 0.049 & 0.676 & 0.508 & 0.466 & 0.272 & 0.123 & 0.358 \\
\hline $\mathrm{NiO}$ & 0.062 & 0.143 & 0.173 & 0.09 & 0.098 & 0.162 & - & 0.088 & 0.084 \\
\hline $\mathrm{V}_{2} \mathrm{O}_{3}$ & - & - & 0.008 & 0.062 & 0.073 & 0.033 & 0.041 & 0.043 & 0.07 \\
\hline $\mathrm{Cl}$ & 0.008 & - & - & 0.137 & 0.183 & 0.151 & 0.197 & 0.111 & 0.227 \\
\hline
\end{tabular}


Table 2.1. (Continued).

\begin{tabular}{|c|c|c|c|c|c|c|c|c|c|}
\hline \multirow{3}{*}{$\begin{array}{l}\text { Samples } \\
\text { Analyses } \\
\text { (Mineral) }\end{array}$} & \multicolumn{9}{|c|}{ Amphibolites } \\
\hline & \multicolumn{5}{|c|}{ PFG-CA-016A } & \multicolumn{4}{|c|}{ TF14-XII-178 } \\
\hline & $\begin{array}{c}1 \text { (Mg- } \\
\text { hornblende) }\end{array}$ & $\begin{array}{c}2(\mathrm{Mg}- \\
\text { hornblende) }\end{array}$ & $\begin{array}{c}3 \text { (Mg- } \\
\text { hornblende) }\end{array}$ & $\begin{array}{c}4 \text { (Mg- } \\
\text { hornblende) }\end{array}$ & $\begin{array}{c}5 \text { (Mg- } \\
\text { hornblende) }\end{array}$ & $\begin{array}{c}1 \text { (Mg- } \\
\text { hornblende) }\end{array}$ & $\begin{array}{c}2 \text { (Mg- } \\
\text { hornblende) }\end{array}$ & $\begin{array}{c}3 \text { (Mg- } \\
\text { hornblende) }\end{array}$ & $\begin{array}{c}4 \\
\text { (Actinolite) }\end{array}$ \\
\hline $\mathrm{SiO}_{2}$ & 48.857 & 49.848 & 49.788 & 51.759 & 49.779 & 49.998 & 49.399 & 50.542 & 55.527 \\
\hline $\mathrm{TiO}_{2}$ & 0.989 & 0.205 & 1.284 & 0.192 & 0.886 & 0.696 & 0.974 & 0.363 & 0.237 \\
\hline $\mathrm{Al}_{2} \mathrm{O}_{3}$ & 6.266 & 6.47 & 5.319 & 4.517 & 5 & 6.381 & 6.475 & 6.332 & 1.608 \\
\hline $\mathrm{FeO}$ & 15.883 & 14.617 & 14.922 & 13.013 & 15.318 & 12.163 & 12.478 & 12.877 & 9.763 \\
\hline $\mathrm{MnO}$ & 0.514 & 0.314 & 0.446 & 0.249 & 0.206 & 0.32 & 0.329 & 0.292 & 0.265 \\
\hline $\mathrm{MgO}$ & 12.496 & 13.438 & 13.304 & 14.72 & 13.325 & 14.093 & 13.722 & 13.844 & 17.364 \\
\hline $\mathrm{CaO}$ & 11.446 & 11.846 & 11.533 & 12.281 & 11.675 & 11.676 & 11.85 & 11.962 & 12.539 \\
\hline $\mathrm{Na}_{2} \mathrm{O}$ & 0.986 & 0.729 & 0.771 & 0.51 & 0.745 & 0.992 & 0.958 & 0.863 & 0.299 \\
\hline $\mathrm{K}_{2} \mathrm{O}$ & 0.336 & 0.288 & 0.296 & 0.103 & 0.335 & 0.181 & 0.184 & 0.145 & 0.018 \\
\hline $\mathrm{Cr}_{2} \mathrm{O}_{3}$ & 0.095 & 0.08 & 0.078 & - & 0.167 & 0.225 & 0.102 & 0.081 & 0.034 \\
\hline $\mathrm{NiO}$ & - & - & - & - & - & 0.06 & 0.028 & 0.004 & 0.066 \\
\hline $\mathrm{V}_{2} \mathrm{O}_{3}$ & 0.094 & 0.089 & 0.048 & 0.066 & 0.013 & 0.085 & 0.075 & - & 0.043 \\
\hline $\mathrm{Cl}$ & 0.075 & 0.066 & 0.077 & 0.026 & 0.048 & 0.004 & 0.02 & 0.004 & 0.016 \\
\hline
\end{tabular}


Table 2.1. (Continued).

\begin{tabular}{|c|c|c|c|c|c|c|c|c|c|}
\hline \multirow{3}{*}{$\begin{array}{l}\text { Samples } \\
\text { Analyses } \\
\text { (Mineral) }\end{array}$} & \multicolumn{9}{|c|}{ Metadiorites } \\
\hline & \multicolumn{5}{|c|}{ PFG-CA-004B } & \multicolumn{4}{|c|}{ TF14-XII0-015A } \\
\hline & $\begin{array}{c}1 \text { (Mg- } \\
\text { hornblende) }\end{array}$ & $\begin{array}{c}2 \text { (Mg- } \\
\text { hornblende) }\end{array}$ & $\begin{array}{c}3 \text { (Mg- } \\
\text { hornblende) }\end{array}$ & $\begin{array}{c}4 \\
\text { (Actinolite) }\end{array}$ & $\begin{array}{c}5 \\
\text { (Actinolite) }\end{array}$ & $\begin{array}{c}1 \\
\text { (Actinolite) }\end{array}$ & $\begin{array}{c}2 \\
\text { (Actinolite) }\end{array}$ & $\begin{array}{c}3 \\
\text { (Actinolite) }\end{array}$ & $\begin{array}{c}4 \\
\text { (Actinolite) }\end{array}$ \\
\hline $\mathrm{SiO}_{2}$ & 49.28 & 49.604 & 48.092 & 55.415 & 54.2 & 54.181 & 57.181 & 54.906 & 55.102 \\
\hline $\mathrm{TiO}_{2}$ & 0.889 & 0.591 & 0.919 & 0.203 & 0.395 & 0.502 & 0.025 & 0.398 & 0.312 \\
\hline $\mathrm{Al}_{2} \mathrm{O}_{3}$ & 6.077 & 6.17 & 6.49 & 1.969 & 3.428 & 3.708 & 1.201 & 3.437 & 3.363 \\
\hline $\mathrm{FeO}$ & 9.963 & 10.855 & 11.257 & 8.408 & 9.09 & 5.391 & 6.342 & 5.497 & 5.966 \\
\hline $\mathrm{MnO}$ & 0.27 & 0.33 & 0.388 & 0.188 & 0.343 & 0.263 & 0.132 & 0.08 & 0.288 \\
\hline $\mathrm{MgO}$ & 15.827 & 14.505 & 14.345 & 17.845 & 16.949 & 19.254 & 19.307 & 19.585 & 19.012 \\
\hline $\mathrm{CaO}$ & 11.937 & 11.563 & 11.678 & 12.651 & 12.452 & 11.87 & 12.976 & 12.279 & 12.198 \\
\hline $\mathrm{Na}_{2} \mathrm{O}$ & 0.963 & 1.313 & 1.194 & 0.294 & 0.448 & 0.519 & 0.206 & 0.652 & 0.569 \\
\hline $\mathrm{K}_{2} \mathrm{O}$ & 0.097 & 0.158 & 0.153 & 0.053 & 0.061 & 0.07 & 0.049 & 0.069 & 0.036 \\
\hline $\mathrm{Cr}_{2} \mathrm{O}_{3}$ & 0.122 & 0.218 & 0.117 & 0.016 & 0.157 & 0.379 & 0.096 & 0.395 & 0.349 \\
\hline $\mathrm{NiO}$ & 0.088 & 0.102 & - & 0.051 & 0.106 & 0.06 & 0.051 & 0.032 & 0.058 \\
\hline $\mathrm{V}_{2} \mathrm{O}_{3}$ & 0.024 & 0.064 & 0.063 & 0.05 & 0.108 & 0.085 & 0.02 & 0.06 & 0.01 \\
\hline $\mathrm{Cl}$ & 0.024 & 0.079 & 0.032 & 0.048 & 0.013 & 0.013 & - & 0.082 & - \\
\hline
\end{tabular}


Table 2.2. Chlorite composition data obtained from eletron microprobe analyses (wt. \%).

\begin{tabular}{|c|c|c|c|c|c|c|c|c|c|}
\hline \multirow{3}{*}{$\begin{array}{c}\text { Samples } \\
\text { Analyses } \\
\text { (Mineral) }\end{array}$} & \multirow{2}{*}{\multicolumn{4}{|c|}{$\begin{array}{c}\text { Ultramafic rock } \\
\text { TF14-I-003 }\end{array}$}} & \multicolumn{2}{|c|}{ Amphibolites } & \multirow{2}{*}{\multicolumn{3}{|c|}{\begin{tabular}{|c|} 
Metadiorite \\
PFG-CA-004B
\end{tabular}}} \\
\hline & & & & & \multirow{2}{*}{$\begin{array}{c}\text { PFG-CA-016A } \\
1 \\
\text { (Ripidolite) }\end{array}$} & \multirow{2}{*}{$\begin{array}{c}\text { TF14-XII-178 } \\
2 \\
\text { (Brunsvigite) }\end{array}$} & & & \\
\hline & $\begin{array}{c}1 \\
\text { (Penninite) }\end{array}$ & $\begin{array}{c}2 \\
\text { (Chlinoclore) }\end{array}$ & $\begin{array}{c}3 \\
\text { (Chlinoclore) }\end{array}$ & $\begin{array}{c}4 \\
\text { (Chlinoclore) }\end{array}$ & & & $\begin{array}{c}1 \\
\text { (Ripidolite) }\end{array}$ & $\begin{array}{c}2 \\
\text { (Brunsvigite) }\end{array}$ & $\begin{array}{c}3 \\
\text { (Brunsvigite) }\end{array}$ \\
\hline $\mathrm{SiO}_{2}$ & 31.024 & 40.903 & 32.932 & 32.766 & 26.623 & 27.478 & 27.583 & 27.92 & 27.676 \\
\hline $\mathrm{TiO}_{2}$ & - & 0.071 & - & - & 0.166 & 0.045 & 0.243 & - & 0.111 \\
\hline $\mathrm{Al}_{2} \mathrm{O}_{3}$ & 15.625 & 2.923 & 14.618 & 13.447 & 21.12 & 21.289 & 20.281 & 20.127 & 21.207 \\
\hline $\mathrm{FeO}$ & 11.659 & 14.557 & 10.624 & 10.292 & 23.375 & 18.581 & 15.9 & 15.825 & 16.273 \\
\hline $\mathrm{MnO}$ & 0.243 & 0.374 & 0.016 & 0.081 & 0.181 & 0.06 & 0.244 & 0.322 & 0.293 \\
\hline $\mathrm{MgO}$ & 30.193 & 31.309 & 31.179 & 31.064 & 17.335 & 19.845 & 22.615 & 22.648 & 21.741 \\
\hline $\mathrm{CaO}$ & 0.006 & 0.029 & 0.004 & 0.003 & 0.028 & 0.008 & 0.035 & - & - \\
\hline $\mathrm{Na}_{2} \mathrm{O}$ & 0.026 & 0.027 & 0.037 & 0.009 & 0.001 & 0.001 & 0.067 & 0.058 & 0.027 \\
\hline $\mathrm{K}_{2} \mathrm{O}$ & 0.019 & 0.019 & 0.029 & 0.02 & 0.028 & 0.012 & 0.023 & 0.112 & 0.062 \\
\hline $\mathrm{Cr}_{2} \mathrm{O}_{3}$ & 0.143 & 0.156 & 0.057 & 0.319 & 0.104 & 0.146 & 0.929 & 0.798 & 0.416 \\
\hline $\mathrm{NiO}$ & 0.071 & 0.163 & 0.085 & 0.187 & 0.007 & 0.105 & 0.092 & 0.018 & 0.035 \\
\hline $\mathrm{V}_{2} \mathrm{O}_{3}$ & - & - & - & - & - & 0.025 & 0.063 & 0.03 & 0.047 \\
\hline $\mathrm{Cl}$ & - & - & - & - & 0.008 & 0.005 & 0.029 & - & - \\
\hline
\end{tabular}


Table 2.3. Plagioclase composition data obtained from eletron microprobe analyses (wt. \%).

\begin{tabular}{|c|c|c|c|c|c|c|c|c|c|}
\hline \multirow{4}{*}{$\begin{array}{l}\text { Samples } \\
\text { Analyses } \\
\text { (Mineral) }\end{array}$} & \multicolumn{6}{|c|}{ Amphibolite } & \multicolumn{3}{|c|}{ Metandesite } \\
\hline & \multicolumn{6}{|c|}{ TF14-XII-178 } & \multicolumn{3}{|c|}{ D19 } \\
\hline & 1 & 2 & 3 & 4 & 5 & 6 & 1 & 2 & 3 \\
\hline & (Albite) & (Albite) & (Albite) & (Albite) & (Albite) & (Albite) & (Albite) & (Albite) & (Albite) \\
\hline $\mathrm{SiO}_{2}$ & 67.817 & 68.506 & 67.977 & 68.483 & 68.302 & 69.024 & 67.98 & 67.964 & 67.707 \\
\hline $\mathrm{TiO}_{2}$ & - & 0.086 & - & 0.091 & - & 0.085 & - & 0.176 & 0.041 \\
\hline $\mathrm{Al}_{2} \mathrm{O}_{3}$ & 20.063 & 19.597 & 19.595 & 19.367 & 19.834 & 19.696 & 19.638 & 19.58 & 19.391 \\
\hline $\mathrm{FeO}$ & 0.156 & 0.076 & 0.059 & 0.068 & 0.061 & 0.051 & 0.045 & 0.023 & 0.052 \\
\hline $\mathrm{MnO}$ & - & 0.008 & - & 0.041 & 0.01 & - & 0.004 & - & - \\
\hline $\mathrm{MgO}$ & - & 0.019 & 0.007 & - & 0.001 & 0.008 & 0.011 & - & - \\
\hline $\mathrm{CaO}$ & 0.607 & 0.217 & 0.453 & 0.272 & 0.327 & 0.397 & 0.092 & 0.093 & 0.083 \\
\hline $\mathrm{Na}_{2} \mathrm{O}$ & 10.566 & 11.188 & 10.999 & 11.161 & 10.719 & 10.594 & 11.498 & 11.143 & 11.727 \\
\hline $\mathrm{K}_{2} \mathrm{O}$ & 0.062 & 0.051 & 0.063 & 0.064 & 0.06 & 0.045 & 0.106 & 0.092 & 0.106 \\
\hline $\mathrm{Cr}_{2} \mathrm{O}_{3}$ & - & 0.008 & - & - & - & 0.004 & - & 0.019 & 0.055 \\
\hline
\end{tabular}


Table 2.3. (Continued).

\begin{tabular}{|c|c|c|c|c|c|c|c|c|c|}
\hline \multirow{4}{*}{$\begin{array}{l}\text { Samples } \\
\text { Analyses } \\
\text { (Mineral) }\end{array}$} & \multirow{2}{*}{\multicolumn{2}{|c|}{$\begin{array}{c}\text { Metandesite } \\
\text { D19 }\end{array}$}} & \multicolumn{7}{|c|}{ Metadiorite } \\
\hline & & & \multicolumn{7}{|c|}{ PFG-CA-004B } \\
\hline & 4 & 5 & 3 & 1 & 2 & 3 & 4 & 5 & 6 \\
\hline & (Albite) & (Albite) & (Albite) & (Albite) & (Albite) & (Albite) & (Albite) & (Albite) & (Albite) \\
\hline $\mathrm{SiO}_{2}$ & 67.752 & 68.106 & 66.622 & 66.51 & 66.685 & 66.815 & 67.073 & 67.861 & 67.234 \\
\hline $\mathrm{TiO}_{2}$ & 0.132 & 0.036 & - & 0.05 & - & 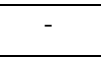 & 0.121 & 0.021 & 0.168 \\
\hline $\mathrm{Al}_{2} \mathrm{O}_{3}$ & 19.374 & 19.476 & 19.509 & 19.735 & 19.732 & 19.514 & 19.867 & 19.258 & 19.976 \\
\hline $\mathrm{FeO}$ & 0.051 & - & 0.054 & 0.039 & 0.023 & - & 0.044 & 0.077 & - \\
\hline $\mathrm{MnO}$ & - & - & - & - & - & - & - & 0.031 & - \\
\hline $\mathrm{MgO}$ & 0.022 & - & - & 0.021 & 0.008 & 0.045 & 0.004 & 0.005 & $\begin{array}{c}- \\
-\end{array}$ \\
\hline $\mathrm{CaO}$ & 0.148 & 0.117 & 0.462 & 0.409 & 0.219 & 0.134 & 0.209 & 0.165 & 0.38 \\
\hline $\mathrm{Na}_{2} \mathrm{O}$ & 11.484 & 11.321 & 10.595 & 10.821 & 10.96 & 10.87 & 10.955 & 10.743 & 10.771 \\
\hline $\mathrm{K}_{2} \mathrm{O}$ & 0.112 & 0.08 & 0.076 & 0.076 & 0.081 & 0.029 & 0.043 & 0.033 & 0.099 \\
\hline $\mathrm{Cr}_{2} \mathrm{O}_{3}$ & - & - & - & 0.003 & - & - & - & 0.013 & - \\
\hline
\end{tabular}




\subsection{Whole rock geochemical data}

Table 3. Major element (wt.\%) and trace-element (ppm) data for metavolcanic and metaplutonic rocks of the Faina and Serra de Santa Rita greenstone belts

\begin{tabular}{|c|c|c|c|c|c|c|c|c|c|}
\hline \multirow[b]{2}{*}{ Samples } & \multicolumn{7}{|c|}{ Ultramafic rocks } & \multicolumn{2}{|c|}{ Chloritites } \\
\hline & TF14-000 & TF14-I-003 & TF14-I-004A & TF14-I-075B & TF14-II-125A & TF14-V-133 & TF14-XII-093 & TF14-XII-167 & TF14-VII-12B \\
\hline $\mathrm{SiO}_{2}$ & 51.5 & 45.5 & 45.1 & 46.9 & 46.7 & 54.9 & 48.7 & 31.2 & 32.3 \\
\hline $\mathrm{TiO}_{2}$ & 0.2 & 0.3 & 0.4 & 0.2 & 0.2 & 0.1 & 0.6 & 1.4 & 1.2 \\
\hline $\mathrm{Al}_{2} \mathrm{O}_{3}$ & 2.9 & 5.8 & 4.4 & 5.7 & 6.8 & 6.2 & 7.7 & 22.9 & 21.7 \\
\hline $\mathrm{Fe}_{2} \mathrm{O}_{3}$ & 10.1 & 15.1 & 15.9 & 14.4 & 10.2 & 8.5 & 13.5 & 15.5 & 13.5 \\
\hline $\mathrm{MnO}$ & 0.1 & 0.2 & 0.2 & 0.2 & 0.1 & 0.1 & 0.2 & 0.1 & 0.1 \\
\hline $\mathrm{MgO}$ & 32.5 & 27.9 & 30.9 & 27.9 & 31.9 & 29.8 & 20.3 & 28.8 & 31.1 \\
\hline $\mathrm{CaO}$ & 1.8 & 5.1 & 2.9 & 5.0 & 4.1 & 0.01 & 8.4 & 0.5 & 0.5 \\
\hline $\mathrm{Na}_{2} \mathrm{O}$ & LDL & 0.1 & 0.1 & 0.04 & 0.1 & 0.01 & 0.3 & 0.03 & LDL \\
\hline $\mathrm{K}_{2} \mathrm{O}$ & LDL & 0.02 & 0.01 & 0.01 & 0.01 & 0.04 & 0.04 & LDL & LDL \\
\hline $\mathrm{P}_{2} \mathrm{O}_{5}$ & 0.02 & 0.02 & 0.03 & 0.01 & 0.01 & LDL & 0.1 & 0.4 & 0.4 \\
\hline LOI & 8.9 & 6.9 & 8.3 & 6.8 & 8.0 & 6.4 & 4.3 & 10.9 & 11.2 \\
\hline$\# \mathrm{Mg}$ & 86 & 79 & 79 & 79 & 86 & 87 & 75 & 79 & 82 \\
\hline $\mathrm{Sc}$ & 13.4 & 24.0 & 21.7 & 25.3 & 20.0 & 18.9 & 28.0 & 19.3 & 11.0 \\
\hline $\mathrm{V}$ & 62 & 124 & 116 & 105 & 89 & 85 & 141 & 213 & 174 \\
\hline $\mathrm{Cr}$ & 2910 & 1680 & 1990 & 1700 & 2550 & 1320 & 2220 & 164 & 80 \\
\hline $\mathrm{Co}$ & 127 & 113 & 121 & 113 & 82.0 & 91.0 & 93.0 & 76.0 & 51.0 \\
\hline $\mathrm{Ni}$ & 2460 & 1105 & 1475 & 1275 & 1630 & 1590 & 905 & 352 & 110 \\
\hline $\mathrm{Rb}$ & 0.2 & 0.3 & 0.2 & 0.1 & 0.6 & 1.7 & 2.4 & 0.3 & 0.4 \\
\hline $\mathrm{Sr}$ & 9.1 & 4.4 & 2.9 & 3.4 & 19.3 & 2.2 & 28.5 & 32.3 & 13.0 \\
\hline $\mathrm{Y}$ & 1.3 & 9.5 & 9.6 & 4.4 & 5.2 & 5.7 & 17.3 & 21.7 & 18.2 \\
\hline $\mathrm{Zr}$ & LDL & 8.2 & 8.4 & 1.9 & 9.0 & 2.9 & 34.0 & 175 & 424 \\
\hline $\mathrm{Hf}$ & LDL & 0.3 & 0.3 & 0.1 & LDL & 0.1 & 0.9 & 3.9 & 8.7 \\
\hline $\mathrm{Nb}$ & 0.6 & 0.6 & 0.8 & 0.4 & 1.2 & 0.1 & 1.5 & 3.4 & 22.1 \\
\hline Cs & 0.1 & LDL & LDL & LDL & 0.1 & 0.2 & 0.2 & LDL & 0.03 \\
\hline $\mathrm{Ba}$ & LDL & 10.0 & LDL & LDL & 3.6 & 20.0 & 5.7 & 30.0 & 6.9 \\
\hline $\mathrm{Ta}$ & 0.2 & 0.1 & 0.1 & LDL & LDL & LDL & 0.1 & 0.3 & 0.9 \\
\hline
\end{tabular}


Table 3. (Continued).

\begin{tabular}{|c|c|c|c|c|c|c|c|c|c|}
\hline \multirow[b]{2}{*}{ Samples } & \multicolumn{7}{|c|}{ Ultramafic rocks } & \multicolumn{2}{|c|}{ Chloritites } \\
\hline & TF14-000 & TF14-I-003 & TF14-I-004A & TF14-I-075B & TF14-II-125A & TF14-V-133 & TF14-XII-093 & TF14-XII-167 & TF14-VII-012B \\
\hline $\mathrm{Pb}$ & 1.4 & 0.5 & LDL & 0.5 & LDL & 5.1 & LDL & 1.1 & LDL \\
\hline Th & LDL & LDL & LDL & LDL & 0.1 & LDL & 0.4 & 4.7 & 6.4 \\
\hline $\mathrm{U}$ & 0.1 & 0.1 & LDL & LDL & LDL & 0.3 & 0.1 & 0.7 & 1.2 \\
\hline $\mathrm{La}$ & 0.8 & 1.1 & 3.0 & 0.6 & 0.7 & 3.9 & 10.8 & 53.4 & 69.5 \\
\hline $\mathrm{Ce}$ & 1.6 & 2.2 & 2.2 & 1.4 & 1.4 & 2.4 & 5.1 & 105 & 137 \\
\hline $\operatorname{Pr}$ & 0.2 & 0.4 & 0.9 & 0.2 & 0.2 & 0.7 & 2.6 & 13.0 & 14.7 \\
\hline $\mathrm{Nd}$ & 1.0 & 2.2 & 4.0 & 1.1 & 0.9 & 2.8 & 10.7 & 52.0 & 55.0 \\
\hline $\mathrm{Sm}$ & 0.3 & 0.7 & 1.1 & 0.4 & 0.2 & 0.6 & 2.3 & 8.8 & 9.0 \\
\hline $\mathrm{Eu}$ & 0.1 & 0.2 & 0.3 & 0.1 & 0.1 & 0.2 & 0.9 & 3.5 & 1.8 \\
\hline $\mathrm{Gd}$ & 0.3 & 1.0 & 1.4 & 0.5 & 0.5 & 0.7 & 3.3 & 6.7 & 6.0 \\
\hline $\mathrm{Tb}$ & 0.1 & 0.2 & 0.3 & 0.1 & 0.1 & 0.1 & 0.5 & 0.8 & 0.8 \\
\hline Dy & 0.3 & 1.6 & 1.9 & 0.9 & 0.7 & 0.8 & 3.1 & 4.2 & 3.8 \\
\hline Ho & 0.1 & 0.4 & 0.4 & 0.2 & 0.2 & 0.2 & 0.6 & 0.8 & 0.7 \\
\hline Er & 0.2 & 1.1 & 1.0 & 0.6 & 0.6 & 0.5 & 1.7 & 1.9 & 1.9 \\
\hline $\mathrm{Tm}$ & 0.02 & 0.2 & 0.2 & 0.1 & 0.1 & 0.1 & 0.2 & 0.3 & 0.3 \\
\hline $\mathrm{Yb}$ & 0.2 & 1.1 & 1.0 & 0.7 & 0.6 & 0.4 & 1.4 & 1.6 & 1.8 \\
\hline $\mathrm{Lu}$ & 0.03 & 0.2 & 0.2 & 0.1 & 0.1 & 0.1 & 0.2 & 0.2 & 0.3 \\
\hline $\mathrm{La} / \mathrm{Yb}_{\mathrm{cn}}$ & 3.38 & 0.70 & 2.22 & 0.61 & 0.84 & 6.36 & 5.53 & 24.71 & 27.09 \\
\hline $\mathrm{La} / \mathrm{Sm}_{\mathrm{cn}}$ & 1.91 & 1.01 & 1.76 & 1.05 & 1.88 & 4.27 & 3.02 & 3.91 & 4.97 \\
\hline $\mathrm{Gd} / \mathrm{Yb}_{\mathrm{cn}}$ & 1.41 & 0.75 & 1.17 & 0.59 & 0.73 & 1.37 & 1.94 & 3.58 & 2.69 \\
\hline$(\mathrm{Eu} / \mathrm{Eu})^{*}$ & 0.55 & 0.86 & 0.80 & 0.84 & 0.94 & 0.93 & 0.96 & 1.40 & 0.73 \\
\hline$(\mathrm{Ce} / \mathrm{Ce})^{*}$ & 0.98 & 0.77 & 0.34 & 0.96 & 0.97 & 0.35 & 0.24 & 0.98 & 1.05 \\
\hline $\mathrm{Nb} / \mathrm{Th}_{\mathrm{pm}}$ & - & - & - & - & 1.19 & - & 0.51 & 0.09 & 0.41 \\
\hline $\mathrm{Ti} / \mathrm{Sm}_{\mathrm{pm}}$ & 1.58 & 0.78 & 0.61 & 0.99 & 1.18 & 0.45 & 0.49 & 0.28 & 0.24 \\
\hline $\mathrm{Zr} / \mathrm{Sm}_{\mathrm{pm}}$ & 0.00 & 0.46 & 0.30 & 0.20 & 1.49 & 0.19 & 0.58 & 0.79 & 1.86 \\
\hline$\sum \mathrm{REE}$ & 9 & 13 & 18 & 8 & 8 & 20 & 38 & 214 & 250 \\
\hline
\end{tabular}


Table 3. (Continued).

\begin{tabular}{|c|c|c|c|c|c|c|c|c|c|}
\hline \multirow[b]{2}{*}{ Samples } & \multirow{2}{*}{$\begin{array}{c}\text { Chloritites } \\
\text { TF14-XI-016 }\end{array}$} & \multicolumn{4}{|c|}{ Amphibolites (Type 1 basalts) } & \multicolumn{3}{|c|}{ Amphibolites (Type 2 basalts) } & \multirow{2}{*}{$\begin{array}{l}\text { Metandesites } \\
\text { PFG-CA-030 } \\
\end{array}$} \\
\hline & & PFG-CA-017A & PFG-CA-019A & PFG-CA-019B & TF14-XI-079B & TF14-XII-178 & TF14-XII-015B & PFG-CA-016A & \\
\hline $\mathrm{SiO}_{2}$ & 31.5 & 54.3 & 53.7 & 53.6 & 52.6 & 55.0 & 52.5 & 54.3 & 67.6 \\
\hline $\mathrm{TiO}_{2}$ & 1.0 & 0.9 & 0.7 & 0.7 & 0.4 & 0.9 & 1.2 & 1.2 & 0.5 \\
\hline $\mathrm{Al}_{2} \mathrm{O}_{3}$ & 21.4 & 11.1 & 8.8 & 10.1 & 10.7 & 15.6 & 14.5 & 13.4 & 15.8 \\
\hline $\mathrm{Fe}_{2} \mathrm{O}_{3}$ & 17.1 & 11.7 & 11.2 & 11.8 & 11.6 & 8.9 & 9.2 & 11.3 & 5.1 \\
\hline $\mathrm{MnO}$ & 0.2 & 0.2 & 0.2 & 0.2 & 0.2 & 0.1 & 0.2 & 0.2 & 0.04 \\
\hline $\mathrm{MgO}$ & 28.4 & 8.8 & 12.2 & 11.4 & 15.1 & 9.0 & 6.9 & 7.2 & 2.7 \\
\hline $\mathrm{CaO}$ & 0.2 & 9.5 & 11.2 & 11.0 & 7.6 & 5.9 & 13.5 & 9.7 & 2.7 \\
\hline $\mathrm{Na}_{2} \mathrm{O}$ & LDL & 3.5 & 1.8 & 1.8 & 2.2 & 4.5 & 2.5 & 2.6 & 4.0 \\
\hline $\mathrm{K}_{2} \mathrm{O}$ & LDL & 0.1 & 0.1 & 0.1 & 0.1 & 0.1 & 0.1 & 0.3 & 1.5 \\
\hline $\mathrm{P}_{2} \mathrm{O}_{5}$ & 0.2 & 0.1 & 0.1 & 0.1 & 0.02 & 0.3 & 0.2 & 0.2 & 0.2 \\
\hline LOI & 10.8 & 1.0 & 1.6 & 1.7 & 3.1 & 2.8 & 1.3 & 1.7 & 3.8 \\
\hline$\# \mathrm{Mg}$ & 77 & 60 & 68 & 66 & 72 & 67 & 60 & 56 & 51 \\
\hline $\mathrm{Sc}$ & 23.0 & 37.0 & 41.0 & 41.0 & 35.0 & 18.9 & 34.0 & 32.0 & 8.0 \\
\hline $\mathrm{V}$ & 164 & 302 & 272 & 280 & 186 & 134 & 235 & 245 & 75 \\
\hline $\mathrm{Cr}$ & 940 & 570 & 870 & 600 & 1280 & 430 & 350 & 340 & 110 \\
\hline Co & 71.0 & 52.0 & 57.0 & 58.0 & 63.0 & 37.3 & 23.0 & 49.0 & 13.0 \\
\hline $\mathrm{Ni}$ & 410 & 191 & 275 & 256 & 384 & 237 & 128 & 110 & 51 \\
\hline $\mathrm{Rb}$ & 0.3 & 1.3 & 1.0 & 0.8 & 0.8 & 2.1 & 1.3 & 7.6 & 38.5 \\
\hline $\mathrm{Sr}$ & 11.1 & 342 & 177 & 143 & 114.5 & 474 & 422 & 331 & 186 \\
\hline $\mathrm{Y}$ & 12.0 & 17.7 & 14.1 & 14.6 & 10.4 & 16.7 & 28.4 & 25.8 & 14.9 \\
\hline $\mathrm{Zr}$ & 163 & 47 & 36 & 38 & 20 & 106 & 97 & 90 & 170 \\
\hline $\mathrm{Hf}$ & 3.6 & 2.5 & 2.7 & 2.6 & 1.3 & 1.1 & 1.1 & 0.3 & 4.5 \\
\hline $\mathrm{Nb}$ & 8.8 & 2.1 & 1.5 & 1.4 & 0.8 & 12.2 & 5.3 & 8.6 & 7.0 \\
\hline $\mathrm{Cs}$ & 0.02 & 0.03 & 0.02 & 0.01 & 0.04 & 0.1 & 0.1 & 0.3 & 0.3 \\
\hline $\mathrm{Ba}$ & 8.8 & 19.0 & 13.9 & 20.2 & 29.5 & 43.3 & 18.9 & 51.3 & 168 \\
\hline $\mathrm{Ta}$ & 0.4 & 0.2 & 0.2 & 0.2 & LDL & 0.5 & 0.3 & 0.4 & 0.5 \\
\hline
\end{tabular}


Table 3. (Continued).

\begin{tabular}{|c|c|c|c|c|c|c|c|c|c|}
\hline \multirow[b]{2}{*}{ Samples } & \multirow{2}{*}{$\begin{array}{c}\text { Chloritites } \\
\text { TF14-XI-016 }\end{array}$} & \multicolumn{4}{|c|}{ Amphibolites (Type 1 basalts) } & \multicolumn{3}{|c|}{ Amphibolites (Type 2 basalts) } & \multirow{2}{*}{$\begin{array}{l}\text { Metandesites } \\
\text { PFG-CA-030 }\end{array}$} \\
\hline & & PFG-CA-017A & PFG-CA-019A & PFG-CA-019B & TF14-XI-079B & TF14-XII-178 & TF14-XII-015B & PFG-CA-016A & \\
\hline $\mathrm{Pb}$ & LDL & 3.0 & LDL & 6.0 & LDL & LDL & LDL & 2.0 & 8.0 \\
\hline Th & 3.8 & 0.2 & 0.2 & 0.2 & 0.1 & 1.2 & 0.9 & 0.8 & 3.2 \\
\hline $\mathrm{U}$ & 0.8 & 0.1 & 0.1 & 0.1 & LDL & 0.3 & 0.4 & 0.2 & 0.8 \\
\hline $\mathrm{La}$ & 20.0 & 2.6 & 2.2 & 2.5 & 1.3 & 15.1 & 9.5 & 7.7 & 25.2 \\
\hline $\mathrm{Ce}$ & 40.1 & 6.4 & 4.6 & 4.9 & 3.4 & 31.5 & 15.4 & 18.6 & 47.5 \\
\hline $\operatorname{Pr}$ & 4.3 & 1.0 & 0.9 & 0.8 & 0.5 & 3.8 & 2.5 & 2.6 & 5.9 \\
\hline $\mathrm{Nd}$ & 16.2 & 4.9 & 3.7 & 4.1 & 2.5 & 15.4 & 10.9 & 11.6 & 21.9 \\
\hline $\mathrm{Sm}$ & 3.0 & 1.7 & 1.3 & 1.4 & 0.9 & 3.6 & 2.9 & 3.1 & 4.0 \\
\hline $\mathrm{Eu}$ & 0.7 & 0.7 & 0.7 & 0.6 & 0.4 & 1.2 & 1.0 & 1.2 & 1.3 \\
\hline $\mathrm{Gd}$ & 2.5 & 2.6 & 2.3 & 2.4 & 1.4 & 3.7 & 4.4 & 4.3 & 3.5 \\
\hline $\mathrm{Tb}$ & 0.4 & 0.5 & 0.4 & 0.4 & 0.2 & 0.5 & 0.8 & 0.7 & 0.6 \\
\hline Dy & 2.3 & 3.2 & 2.6 & 2.7 & 1.6 & 3.0 & 4.7 & 4.8 & 3.1 \\
\hline Ho & 0.4 & 0.7 & 0.5 & 0.5 & 0.4 & 0.6 & 1.0 & 1.0 & 0.6 \\
\hline Er & 1.3 & 2.0 & 1.6 & 1.4 & 1.2 & 1.5 & 3.1 & 2.9 & 1.4 \\
\hline $\mathrm{Tm}$ & 0.2 & 0.3 & 0.2 & 0.2 & 0.2 & 0.3 & 0.5 & 0.4 & 0.2 \\
\hline $\mathrm{Yb}$ & 1.3 & 1.6 & 1.4 & 1.2 & 1.2 & 1.6 & 2.7 & 2.7 & 1.2 \\
\hline $\mathrm{Lu}$ & 0.2 & 0.3 & 0.2 & 0.2 & 0.2 & 0.3 & 0.5 & 0.4 & 0.2 \\
\hline $\mathrm{La} / \mathrm{Yb}_{\text {cn }}$ & 11.12 & 1.17 & 1.14 & 1.53 & 0.79 & 6.90 & 2.51 & 2.04 & 14.58 \\
\hline $\mathrm{La} / \mathrm{Sm}_{\mathrm{cn}}$ & 4.28 & 1.01 & 1.09 & 1.14 & 0.94 & 2.73 & 2.11 & 1.62 & 4.12 \\
\hline $\mathrm{Gd} / \mathrm{Yb}_{\mathrm{cn}}$ & 1.60 & 1.35 & 1.37 & 1.67 & 1.00 & 1.95 & 1.34 & 1.31 & 2.34 \\
\hline$(\mathrm{Eu} / \mathrm{Eu})^{*}$ & 0.72 & 1.04 & 1.24 & 0.92 & 0.98 & 1.04 & 0.89 & 1.04 & 1.07 \\
\hline$(\mathrm{Ce} / \mathrm{Ce})^{*}$ & 1.06 & 0.99 & 0.82 & 0.84 & 1.01 & 1.03 & 0.78 & 1.02 & 0.96 \\
\hline $\mathrm{Nb} / \mathrm{Th}_{\mathrm{pm}}$ & 0.28 & 1.04 & 0.99 & 0.88 & 0.95 & 1.17 & 0.68 & 1.27 & 0.26 \\
\hline $\mathrm{Ti} / \mathrm{Sm}_{\mathrm{pm}}$ & 0.61 & 1.06 & 1.12 & 1.04 & 0.94 & 0.49 & 0.84 & 0.79 & 0.27 \\
\hline $\mathrm{Zr} / \mathrm{Sm}_{\mathrm{pm}}$ & 2.14 & 1.12 & 1.10 & 1.06 & 0.89 & 1.18 & 1.33 & 1.16 & 1.71 \\
\hline$\sum \mathrm{REE}$ & 84 & 27 & 22 & 23 & 15 & 73 & 52 & 55 & 104 \\
\hline
\end{tabular}


Table 3. (Continued).

\begin{tabular}{|c|c|c|c|c|c|c|c|c|c|}
\hline \multirow[b]{2}{*}{ Samples } & \multicolumn{4}{|c|}{ Metandesites } & \multicolumn{5}{|c|}{ Metadiorites } \\
\hline & D22 & D23 & D24 & D26 & PFG-CA-004A & PFG-CA-004B & PFG-CA-004D & PFG-CA-004E & PFG-CA-004G \\
\hline $\mathrm{SiO}_{2}$ & 63.2 & 57.5 & 61.3 & 56.0 & 58.2 & 55.6 & 56.2 & 54.4 & 55.4 \\
\hline $\mathrm{TiO}_{2}$ & 0.7 & 0.8 & 0.7 & 1.1 & 0.6 & 1.2 & 0.3 & 0.6 & 1.1 \\
\hline $\mathrm{Al}_{2} \mathrm{O}_{3}$ & 15.9 & 16.2 & 16.7 & 20.5 & 15.1 & 13.1 & 14.5 & 12.6 & 14.6 \\
\hline $\mathrm{Fe}_{2} \mathrm{O}_{3}$ & 5.3 & 7.3 & 6.3 & 7.7 & 7.6 & 8.0 & 9.8 & 9.4 & 7.1 \\
\hline $\mathrm{MnO}$ & 0.1 & 0.1 & 0.1 & 0.1 & 0.1 & 0.1 & 0.2 & 0.2 & 0.1 \\
\hline $\mathrm{MgO}$ & 4.2 & 5.8 & 4.9 & 4.6 & 8.8 & 11.9 & 11.2 & 12.5 & 9.9 \\
\hline $\mathrm{CaO}$ & 5.6 & 6.4 & 5.8 & 5.6 & 5.3 & 6.3 & 4.7 & 6.2 & 5.5 \\
\hline $\mathrm{Na}_{2} \mathrm{O}$ & 5.0 & 5.2 & 5.1 & 6.0 & 5.1 & 4.3 & 4.1 & 3.6 & 5.3 \\
\hline $\mathrm{K}_{2} \mathrm{O}$ & 0.3 & 0.3 & 0.3 & 0.1 & 0.1 & 0.1 & 0.1 & 0.1 & 0.2 \\
\hline $\mathrm{P}_{2} \mathrm{O}_{5}$ & 0.2 & 0.2 & 0.2 & 0.2 & 0.2 & 0.5 & 0.1 & 0.3 & 0.6 \\
\hline LOI & 2.4 & 2.5 & 2.1 & 2.8 & 2.4 & 2.6 & 3.1 & 2.9 & 2.4 \\
\hline$\# \mathrm{Mg}$ & 61 & 61 & 61 & 54 & 70 & 75 & 69 & 72 & 74 \\
\hline $\mathrm{Sc}$ & - & - & - & - & 16.0 & 21.0 & 13.0 & 14.0 & 21.0 \\
\hline $\mathrm{V}$ & 104 & 140 & 119 & 167 & 97 & 134 & 80 & 99 & 145 \\
\hline $\mathrm{Cr}$ & 180 & 230 & 240 & 60 & 440 & 910 & 780 & 840 & 710 \\
\hline Co & 21.4 & 30.1 & 22.9 & 23.4 & 37.0 & 43.0 & 44.0 & 45.0 & 40.0 \\
\hline $\mathrm{Ni}$ & 99 & 128 & 110 & 78 & 231 & 247 & 347 & 473 & 200 \\
\hline $\mathrm{Rb}$ & 8.2 & 7.7 & 6.8 & 1.6 & 1.7 & 3.9 & 1.6 & 2.0 & 4.0 \\
\hline $\mathrm{Sr}$ & 584 & 606 & 616 & 494 & 485 & 309 & 264 & 200 & 481 \\
\hline $\mathrm{Y}$ & 14.3 & 14.7 & 14.1 & 27.4 & 12.4 & 17.0 & 8.4 & 11.4 & 16.8 \\
\hline $\mathrm{Zr}$ & 164 & 126 & 114 & 171 & 82 & 136 & 54 & 153 & 252 \\
\hline $\mathrm{Hf}$ & 4.3 & 3.5 & 2.9 & 4.5 & 2.2 & 3.5 & 1.4 & 3.5 & 5.2 \\
\hline $\mathrm{Nb}$ & 7.9 & 5.5 & 5.5 & 7.2 & 4.9 & 10.3 & 2.6 & 4.7 & 11.0 \\
\hline Cs & 0.1 & 0.2 & 0.1 & 0.03 & 0.1 & 0.2 & 0.03 & 0.1 & 0.2 \\
\hline $\mathrm{Ba}$ & 97.9 & 43.5 & 88.3 & 15.4 & 53.7 & 38.3 & 17.6 & 30.7 & 59.5 \\
\hline $\mathrm{Ta}$ & 0.4 & 0.3 & 0.4 & 0.5 & 0.3 & 0.6 & 0.2 & 0.3 & 0.6 \\
\hline
\end{tabular}


Table 3. (Continued).

\begin{tabular}{|c|c|c|c|c|c|c|c|c|c|}
\hline \multirow[b]{2}{*}{ Sample } & \multicolumn{4}{|c|}{ Metandesites } & \multicolumn{5}{|c|}{ Metadiorites } \\
\hline & D22 & D23 & D24 & D26 & PFG-CA-004A & PFG-CA-004B & PFG-CA-004D & PFG-CA-004E & PFG-CA-004G \\
\hline $\mathrm{Pb}$ & 8.0 & 10.0 & 10.0 & 7.0 & LDL & 3.0 & LDL & LDL & LDL \\
\hline Th & 3.6 & 2.3 & 2.4 & 2.4 & 1.5 & 1.8 & 0.4 & 0.9 & 1.7 \\
\hline $\mathrm{U}$ & 0.7 & 0.6 & 0.6 & 0.7 & 0.5 & 0.5 & 0.1 & 0.3 & 0.6 \\
\hline $\mathrm{La}$ & 22.4 & 15.7 & 17.3 & 16.5 & 14.8 & 29.4 & 10.8 & 17.9 & 31.4 \\
\hline $\mathrm{Ce}$ & 46.8 & 33.3 & 35.5 & 37.8 & 30.5 & 66.7 & 22.5 & 38.0 & 67.2 \\
\hline $\operatorname{Pr}$ & 5.1 & 3.8 & 4.0 & 4.3 & 3.8 & 8.6 & 2.8 & 4.9 & 8.4 \\
\hline $\mathrm{Nd}$ & 19.1 & 16.3 & 15.9 & 18.2 & 13.6 & 34.3 & 11.4 & 19.3 & 33.2 \\
\hline $\mathrm{Sm}$ & 3.8 & 3.5 & 3.3 & 4.2 & 2.9 & 6.5 & 2.2 & 3.3 & 6.3 \\
\hline $\mathrm{Eu}$ & 1.3 & 1.3 & 1.1 & 1.5 & 1.0 & 1.9 & 1.0 & 1.1 & 2.0 \\
\hline $\mathrm{Gd}$ & 3.5 & 3.4 & 3.7 & 5.1 & 2.7 & 5.5 & 2.2 & 3.1 & 5.4 \\
\hline $\mathrm{Tb}$ & 0.4 & 0.5 & 0.4 & 0.8 & 0.4 & 0.7 & 0.3 & 0.4 & 0.7 \\
\hline Dy & 2.6 & 2.9 & 2.5 & 4.9 & 2.3 & 3.7 & 1.7 & 2.3 & 3.7 \\
\hline Ho & 0.5 & 0.5 & 0.6 & 0.9 & 0.4 & 0.6 & 0.3 & 0.4 & 0.7 \\
\hline $\mathrm{Er}$ & 1.3 & 1.3 & 1.5 & 2.3 & 1.3 & 1.7 & 0.9 & 1.1 & 1.6 \\
\hline $\mathrm{Tm}$ & 0.2 & 0.2 & 0.2 & 0.4 & 0.2 & 0.2 & 0.1 & 0.2 & 0.2 \\
\hline $\mathrm{Yb}$ & 1.5 & 1.6 & 1.4 & 2.5 & 1.3 & 1.2 & 0.7 & 1.0 & 1.2 \\
\hline $\mathrm{Lu}$ & 0.2 & 0.2 & 0.2 & 0.3 & 0.2 & 0.2 & 0.1 & 0.2 & 0.2 \\
\hline $\mathrm{La} / \mathrm{Yb}_{\mathrm{cn}}$ & 10.43 & 7.08 & 9.06 & 4.70 & 8.49 & 18.34 & 11.07 & 12.84 & 18.61 \\
\hline $\mathrm{La} / \mathrm{Sm}_{\mathrm{cn}}$ & 3.79 & 2.87 & 3.34 & 2.55 & 3.34 & 2.93 & 3.24 & 3.47 & 3.24 \\
\hline $\mathrm{Gd} / \mathrm{Yb}_{\mathrm{cn}}$ & 1.86 & 1.75 & 2.24 & 1.66 & 1.81 & 3.93 & 2.58 & 2.59 & 3.69 \\
\hline$(\mathrm{Eu} / \mathrm{Eu})^{*}$ & 1.09 & 1.12 & 0.96 & 1.02 & 1.07 & 0.98 & 1.37 & 1.05 & 1.05 \\
\hline$(\mathrm{Ce} / \mathrm{Ce})^{*}$ & 1.08 & 1.06 & 1.05 & 1.11 & 1.00 & 1.03 & 1.00 & 0.99 & 1.01 \\
\hline $\mathrm{Nb} / \mathrm{Th}_{\mathrm{pm}}$ & 0.26 & 0.28 & 0.28 & 0.35 & 0.39 & 0.67 & 0.84 & 0.63 & 0.77 \\
\hline $\mathrm{Ti} / \mathrm{Sm}_{\mathrm{pm}}$ & 0.36 & 0.45 & 0.41 & 0.53 & 0.41 & 0.35 & 0.24 & 0.38 & 0.35 \\
\hline $\mathrm{Zr} / \mathrm{Sm}_{\mathrm{pm}}$ & 1.70 & 1.42 & 1.35 & 1.62 & 1.14 & 0.83 & 1.00 & 1.82 & 1.60 \\
\hline$\sum \mathrm{REE}$ & 96 & 75 & 79 & 86 & 69 & 144 & 58 & 87 & 144 \\
\hline
\end{tabular}


Table 3. (Continued).

\begin{tabular}{|c|c|c|c|}
\hline \multirow[b]{2}{*}{ Samples } & \multicolumn{2}{|c|}{ Metadiorites } & \multirow{2}{*}{$\begin{array}{l}\text { Metatonalite } \\
\text { TF14-XII-183 }\end{array}$} \\
\hline & TF14-XII-015A & PFG-CA-016B & \\
\hline $\mathrm{SiO}_{2}$ & 56.7 & 54.8 & 66.0 \\
\hline $\mathrm{TiO}_{2}$ & 0.4 & 0.8 & 0.7 \\
\hline$\overline{\mathrm{Al}_{2} \mathrm{O}_{3}}$ & 12.6 & 12.7 & 15.0 \\
\hline $\mathrm{Fe}_{2} \mathrm{O}_{3}$ & 6.8 & 8.8 & 4.8 \\
\hline $\mathrm{MnO}$ & 0.1 & 0.2 & 0.1 \\
\hline $\mathrm{MgO}$ & 14.6 & 12.5 & 1.7 \\
\hline $\mathrm{CaO}$ & 5.7 & 7.4 & 7.3 \\
\hline $\mathrm{Na}_{2} \mathrm{O}$ & 1.2 & 3.2 & 4.9 \\
\hline $\mathrm{K}_{2} \mathrm{O}$ & 1.4 & 0.5 & 0.1 \\
\hline $\mathrm{P}_{2} \mathrm{O}_{5}$ & 0.1 & 0.3 & 0.1 \\
\hline LOI & 3.9 & 2.5 & 0.6 \\
\hline$\# \mathrm{Mg}$ & 81 & 74 & 42 \\
\hline $\mathrm{Sc}$ & 18.0 & 13.0 & 12.2 \\
\hline $\mathrm{V}$ & 111 & 99 & 96 \\
\hline $\mathrm{Cr}$ & 1060 & 1000 & 330 \\
\hline Co & 43.0 & 48.0 & 16.4 \\
\hline $\mathrm{Ni}$ & 456 & 378 & 120 \\
\hline $\mathrm{Rb}$ & 30.6 & 14.6 & 1.0 \\
\hline $\mathrm{Sr}$ & 44.1 & 167.0 & 925.0 \\
\hline $\mathrm{Y}$ & 9.7 & 13.5 & 8.1 \\
\hline $\mathrm{Zr}$ & 67 & 140 & 145 \\
\hline $\mathrm{Hf}$ & 1.5 & 3.6 & 3.3 \\
\hline $\mathrm{Nb}$ & 2.6 & 12.8 & 5.0 \\
\hline Cs & 0.4 & 0.4 & 0.1 \\
\hline $\mathrm{Ba}$ & 618 & 230 & 16.2 \\
\hline $\mathrm{Ta}$ & LDL & 0.8 & 0.3 \\
\hline
\end{tabular}


Table 3. (Continued).

\begin{tabular}{|c|c|c|c|}
\hline \multirow[b]{2}{*}{ Samples } & \multicolumn{2}{|c|}{ Metadiorites } & \multirow{2}{*}{$\begin{array}{c}\text { Metatonalite } \\
\text { Samples }\end{array}$} \\
\hline & TF14-XII-015A & PFG-CA-016B & \\
\hline $\mathrm{Pb}$ & LDL & LDL & LDL \\
\hline Th & 1.4 & 2.6 & 1.7 \\
\hline $\mathrm{U}$ & 0.5 & 0.6 & 0.6 \\
\hline $\mathrm{La}$ & 11.9 & 26.2 & 13.5 \\
\hline $\mathrm{Ce}$ & 17.5 & 53.7 & 27.6 \\
\hline $\operatorname{Pr}$ & 2.5 & 6.2 & 3.2 \\
\hline $\mathrm{Nd}$ & 9.1 & 23.1 & 13.7 \\
\hline $\mathrm{Sm}$ & 1.9 & 4.1 & 3.0 \\
\hline $\mathrm{Eu}$ & 0.5 & 1.2 & 1.1 \\
\hline $\mathrm{Gd}$ & 1.8 & 3.5 & 2.1 \\
\hline $\mathrm{Tb}$ & 0.3 & 0.5 & 0.3 \\
\hline Dy & 1.8 & 2.7 & 1.5 \\
\hline Ho & 0.3 & 0.5 & 0.3 \\
\hline $\mathrm{Er}$ & 1.1 & 1.3 & 1.0 \\
\hline $\mathrm{Tm}$ & 0.1 & 0.2 & 0.1 \\
\hline $\mathrm{Yb}$ & 0.9 & 1.1 & 0.8 \\
\hline $\mathrm{Lu}$ & 0.1 & 0.2 & 0.1 \\
\hline $\mathrm{La} / \mathrm{Yb}_{\mathrm{cn}}$ & 9.93 & 16.78 & 12.58 \\
\hline $\mathrm{La} / \mathrm{Sm}_{\mathrm{cn}}$ & 4.13 & 4.18 & 2.91 \\
\hline $\mathrm{Gd} / \mathrm{Yb}_{\mathrm{cn}}$ & 1.75 & 2.56 & 2.22 \\
\hline$(\mathrm{Eu} / \mathrm{Eu})^{*}$ & 0.81 & 0.98 & 1.30 \\
\hline$(\mathrm{Ce} / \mathrm{Ce})^{*}$ & 0.79 & 1.03 & 1.02 \\
\hline $\mathrm{Nb} / \mathrm{Th}_{\mathrm{pm}}$ & 0.22 & 0.59 & 0.34 \\
\hline $\mathrm{Ti} / \mathrm{Sm}_{\mathrm{pm}}$ & 0.43 & 0.39 & 0.45 \\
\hline $\mathrm{Zr} / \mathrm{Sm}_{\mathrm{pm}}$ & 1.43 & 1.37 & 1.92 \\
\hline$\sum \mathrm{REE}$ & 49 & 113 & 67 \\
\hline
\end{tabular}




\subsection{Summary of zircon in situ LA-ICP-MS U-Pb isotopic analytical data}

Table 4.1. Summary of U-Pb zircon data of sample TF14-I-099 (chloritite of the Faina greenstone belt) obtained by LA-SF-ICP-MS method.

\begin{tabular}{|c|c|c|c|c|c|c|c|c|c|c|c|c|c|c|}
\hline \multirow{2}{*}{$\begin{array}{c}\text { Sample } \\
\text { TF14-I-099 } \\
\text { Spot number }\end{array}$} & \multicolumn{7}{|c|}{ Isotopic ratios } & \multicolumn{7}{|c|}{ Ages (Ma) } \\
\hline & ${ }^{207} \mathrm{~Pb} /{ }^{206} \mathrm{~Pb}$ & $\pm 1 \sigma$ & ${ }^{207} \mathrm{~Pb} /{ }^{235} \mathbf{U}$ & $\pm 1 \sigma$ & ${ }^{206} \mathbf{P b} /{ }^{238} \mathbf{U}$ & $\pm 1 \sigma$ & Rho & ${ }^{206} \mathrm{~Pb} /{ }^{238} \mathrm{U}$ & $\pm 1 \sigma$ & ${ }^{207} \mathrm{~Pb} /{ }^{235} \mathrm{U}$ & $\pm 1 \sigma$ & ${ }^{206} \mathrm{~Pb} /{ }^{207} \mathrm{~Pb}$ & $\pm 1 \sigma$ & Conc. \\
\hline SMPABC147 & 0.1761 & 0.0027 & 8.79 & 0.12 & 0.3641 & 0.0031 & 0.62 & 2002 & 14 & 2316 & 12 & 2616 & 25 & 77 \\
\hline SMPABC143 & 0.2188 & 0.0035 & 13.26 & 0.20 & 0.4443 & 0.0041 & 0.63 & 2370 & 18 & 2698 & 14 & 2972 & 26 & 80 \\
\hline SMPABC142 & 0.2000 & 0.0023 & 13.56 & 0.13 & 0.4959 & 0.0039 & 0.82 & 2596 & 17 & 2719 & 9 & 2826 & 19 & 92 \\
\hline SMPABC139 & 0.2197 & 0.0037 & 16.92 & 0.26 & 0.5653 & 0.0057 & 0.65 & 2889 & 23 & 2930 & 15 & 2978 & 27 & 97 \\
\hline SMPABC138 & 0.2099 & 0.0026 & 15.23 & 0.16 & 0.5296 & 0.0044 & 0.78 & 2740 & 18 & 2830 & 10 & 2904 & 20 & 94 \\
\hline SMPABC125 & 0.1770 & 0.0021 & 7.50 & 0.07 & 0.3092 & 0.0025 & 0.81 & 1737 & 12 & 2173 & 9 & 2625 & 19 & 66 \\
\hline SMPABC122 & 0.1937 & 0.0022 & 12.16 & 0.11 & 0.4580 & 0.0036 & 0.86 & 2431 & 16 & 2617 & 9 & 2774 & 18 & 88 \\
\hline SMPABC119 & 0.2011 & 0.0022 & 14.59 & 0.13 & 0.5292 & 0.0041 & 0.87 & 2738 & 17 & 2789 & 9 & 2835 & 18 & 97 \\
\hline SMPABC109 & 0.1864 & 0.0020 & 10.12 & 0.09 & 0.3957 & 0.0031 & 0.88 & 2149 & 14 & 2446 & 8 & 2710 & 18 & 79 \\
\hline SMPABC107 & 0.1705 & 0.0019 & 8.26 & 0.07 & 0.3532 & 0.0027 & 0.88 & 1950 & 13 & 2261 & 8 & 2562 & 18 & 76 \\
\hline SMPABC105 & 0.1828 & 0.0020 & 8.07 & 0.07 & 0.3217 & 0.0025 & 0.88 & 1798 & 12 & 2239 & 8 & 2678 & 18 & 67 \\
\hline SMPABC104 & 0.1945 & 0.0021 & 10.26 & 0.09 & 0.3843 & 0.0030 & 0.89 & 2097 & 14 & 2459 & 8 & 2780 & 18 & 75 \\
\hline SMPABC103 & 0.1609 & 0.0018 & 6.21 & 0.05 & 0.2811 & 0.0022 & 0.87 & 1597 & 11 & 2006 & 8 & 2465 & 18 & 65 \\
\hline SMPABC100 & 0.1848 & 0.0020 & 9.85 & 0.08 & 0.3880 & 0.0030 & 0.89 & 2113 & 14 & 2421 & 8 & 2696 & 18 & 78 \\
\hline
\end{tabular}


Table 4.2. Summary of U-Pb zircon data of sample TF14-XI-016 (chloritite of the Serra de Santa Rita greenstone belt) obtained by LA-MS-ICP-MS method.

\begin{tabular}{|c|c|c|c|c|c|c|c|c|c|c|c|c|c|c|}
\hline \multirow{2}{*}{$\begin{array}{c}\begin{array}{c}\text { Sample } \\
\text { TF14-XI-016 }\end{array} \\
\text { Spot number }\end{array}$} & \multicolumn{7}{|c|}{ Isotopic ratios } & \multicolumn{7}{|c|}{ Ages (Ma) } \\
\hline & ${ }^{207} \mathrm{~Pb} /{ }^{206} \mathrm{~Pb}$ & $\pm 1 \sigma$ & ${ }^{207} \mathbf{P b} /{ }^{235} \mathbf{U}$ & $\pm 1 \sigma$ & ${ }^{206} \mathrm{~Pb} /{ }^{238} \mathrm{U}$ & $\pm 1 \sigma$ & Rho & ${ }^{206} \mathrm{~Pb} /{ }^{238} \mathrm{U}$ & $\pm 1 \sigma$ & ${ }^{207} \mathbf{P b} /{ }^{235} \mathbf{U}$ & $\pm 1 \sigma$ & ${ }^{207} \mathrm{~Pb} /{ }^{206} \mathrm{~Pb}$ & $\pm 1 \sigma$ & Conc. \\
\hline 004-Z01 & 0.213 & 1.432 & 16.817 & 2.261 & 0.573 & 1.750 & 0.769 & 2921 & 41 & 2924 & 22 & 2927 & 23 & 100 \\
\hline 005-Z02 & 0.222 & 1.379 & 16.686 & 2.033 & 0.545 & 1.493 & 0.727 & 2804 & 34 & 2917 & 19 & 2996 & 22 & 96 \\
\hline 006-Z03 & 0.219 & 1.736 & 17.524 & 2.472 & 0.581 & 1.760 & 0.706 & 2951 & 42 & 2964 & 24 & 2972 & 28 & 100 \\
\hline 007-Z04 & 0.218 & 1.528 & 17.243 & 2.367 & 0.575 & 1.808 & 0.759 & 2928 & 43 & 2948 & 23 & 2963 & 25 & 99 \\
\hline 008-Z05 & 0.220 & 2.406 & 16.975 & 3.550 & 0.559 & 2.611 & 0.733 & 2861 & 60 & 2933 & 34 & 2983 & 39 & 98 \\
\hline 009-Z06 & 0.222 & 2.429 & 17.758 & 3.519 & 0.580 & 2.546 & 0.721 & 2951 & 60 & 2977 & 34 & 2994 & 39 & 99 \\
\hline 010-Z07 & 0.217 & 3.340 & 17.501 & 4.851 & 0.584 & 3.518 & 0.724 & 2964 & 84 & 2963 & 47 & 2962 & 54 & 100 \\
\hline 013-Z08 & 0.216 & 1.012 & 17.946 & 1.443 & 0.602 & 1.028 & 0.695 & 3039 & 25 & 2987 & 14 & 2952 & 16 & 102 \\
\hline 014-Z09 & 0.215 & 1.483 & 17.337 & 2.207 & 0.584 & 1.634 & 0.734 & 2966 & 39 & 2954 & 21 & 2946 & 24 & 100 \\
\hline 015-Z10 & 0.222 & 1.402 & 17.045 & 2.122 & 0.557 & 1.593 & 0.744 & 2854 & 37 & 2937 & 20 & 2995 & 23 & 97 \\
\hline 016-Z11 & 0.220 & 0.855 & 17.899 & 1.509 & 0.590 & 1.244 & 0.815 & 2990 & 30 & 2984 & 15 & 2980 & 14 & 100 \\
\hline 017-Z12 & 0.218 & 0.852 & 17.656 & 1.719 & 0.588 & 1.493 & 0.864 & 2981 & 36 & 2971 & 17 & 2965 & 14 & 100 \\
\hline 018-Z13 & 0.217 & 0.470 & 17.176 & 1.136 & 0.573 & 1.034 & 0.903 & 2919 & 24 & 2945 & 11 & 2962 & 8 & 99 \\
\hline 019-Z14 & 0.213 & 1.671 & 17.428 & 2.998 & 0.592 & 2.490 & 0.828 & 2999 & 60 & 2959 & 29 & 2932 & 27 & 101 \\
\hline $020-Z 15$ & 0.217 & 3.206 & 18.485 & 4.361 & 0.617 & 2.957 & 0.676 & 3100 & 73 & 3015 & 42 & 2959 & 52 & 103 \\
\hline 023-Z16 & 0.220 & 0.632 & 17.821 & 1.026 & 0.588 & 0.808 & 0.763 & 2982 & 19 & 2980 & 10 & 2979 & 10 & 100 \\
\hline 024-Z17 & 0.199 & 0.411 & 9.952 & 0.908 & 0.363 & 0.810 & 0.877 & 1996 & 14 & 2430 & 8 & 2817 & 7 & 82 \\
\hline 025-Z18 & 0.216 & 0.851 & 17.108 & 1.568 & 0.574 & 1.317 & 0.833 & 2924 & 31 & 2941 & 15 & 2952 & 14 & 99 \\
\hline 026-Z19 & 0.216 & 0.630 & 17.949 & 1.059 & 0.602 & 0.852 & 0.783 & 3037 & 21 & 2987 & 10 & 2954 & 10 & 102 \\
\hline 027-Z20 & 0.217 & 0.528 & 17.668 & 0.979 & 0.589 & 0.824 & 0.823 & 2987 & 20 & 2972 & 9 & 2962 & 9 & 101 \\
\hline $028-\mathrm{Z} 21$ & 0.218 & 0.758 & 17.174 & 1.565 & 0.572 & 1.369 & 0.870 & 2918 & 32 & 2945 & 15 & 2963 & 12 & 99 \\
\hline 029-Z22 & 0.219 & 0.412 & 18.678 & 0.887 & 0.619 & 0.785 & 0.869 & 3107 & 19 & 3025 & 9 & 2971 & 7 & 103 \\
\hline $030-\mathrm{Z} 23$ & 0.220 & 0.754 & 17.149 & 1.229 & 0.566 & 0.970 & 0.773 & 2890 & 23 & 2943 & 12 & 2980 & 12 & 98 \\
\hline 033-Z24 & 0.217 & 0.510 & 18.713 & 1.128 & 0.624 & 1.006 & 0.883 & 3126 & 25 & 3027 & 11 & 2962 & 8 & 103 \\
\hline 034-Z25 & 0.217 & 0.712 & 17.230 & 1.265 & 0.576 & 1.046 & 0.814 & 2933 & 25 & 2948 & 12 & 2958 & 11 & 99 \\
\hline $035-Z 26$ & 0.218 & 0.646 & 17.607 & 0.983 & 0.587 & 0.741 & 0.721 & 2977 & 18 & 2968 & 9 & 2963 & 10 & 100 \\
\hline
\end{tabular}


Table 4.2. (Continued).

\begin{tabular}{|c|c|c|c|c|c|c|c|c|c|c|c|c|c|c|}
\hline \multirow{2}{*}{$\begin{array}{c}\begin{array}{c}\text { Sample } \\
\text { TF14-XI-016 }\end{array} \\
\text { Spot number }\end{array}$} & \multicolumn{7}{|c|}{ Isotopic ratios } & \multicolumn{7}{|c|}{ Ages (Ma) } \\
\hline & ${ }^{207} \mathrm{~Pb} /{ }^{206} \mathrm{~Pb}$ & $\pm 1 \sigma$ & ${ }^{207} \mathrm{~Pb} /{ }^{235} \mathrm{U}$ & $\pm 1 \sigma$ & ${ }^{206} \mathbf{P b} /{ }^{238} \mathbf{U}$ & $\pm 1 \sigma$ & Rho & ${ }^{206} \mathrm{~Pb} /{ }^{238} \mathrm{U}$ & $\pm 1 \sigma$ & ${ }^{207} \mathbf{P b} /{ }^{235} \mathbf{U}$ & $\pm 1 \sigma$ & ${ }^{207} \mathrm{~Pb} /{ }^{206} \mathrm{~Pb}$ & $\pm 1 \sigma$ & Conc. \\
\hline $036-\mathrm{Z} 27$ & 0.218 & 0.602 & 17.298 & 1.162 & 0.575 & 0.994 & 0.843 & 2927 & 23 & 2952 & 11 & 2968 & 10 & 99 \\
\hline 037-Z28 & 0.213 & 0.643 & 16.934 & 1.252 & 0.576 & 1.075 & 0.848 & 2931 & 25 & 2931 & 12 & 2931 & 10 & 100 \\
\hline 038-Z29 & 0.219 & 0.755 & 17.220 & 1.260 & 0.570 & 1.009 & 0.786 & 2906 & 24 & 2947 & 12 & 2975 & 12 & 99 \\
\hline
\end{tabular}

Table 4.3. Summary of U-Pb zircon data of sample TF14-XII-178 (amphibolite of the Serra de Santa Rita greenstone belt) obtained by LA-SF-ICP-MS method.

\begin{tabular}{|c|c|c|c|c|c|c|c|c|c|c|c|c|c|c|}
\hline \multirow{2}{*}{$\begin{array}{c}\begin{array}{c}\text { Sample } \\
\text { TF14-XII-178 }\end{array} \\
\text { Spot number }\end{array}$} & \multicolumn{7}{|c|}{ Isotopic ratios } & \multicolumn{7}{|c|}{ Ages (Ma) } \\
\hline & ${ }^{207} \mathrm{~Pb} /{ }^{206} \mathrm{~Pb}$ & $\pm 1 \sigma$ & ${ }^{207} \mathrm{~Pb} /{ }^{235} \mathbf{U}$ & $\pm 1 \sigma$ & ${ }^{2066} \mathrm{~Pb} /{ }^{238} \mathrm{U}$ & $\pm 1 \sigma$ & Rho & ${ }^{206} \mathrm{~Pb} /{ }^{238} \mathrm{U}$ & $\pm 1 \sigma$ & ${ }^{207} \mathrm{~Pb} /{ }^{235} \mathbf{U}$ & $\pm 1 \sigma$ & ${ }^{206} \mathrm{~Pb} /{ }^{207} \mathrm{~Pb}$ & $\pm 1 \sigma$ & Conc. \\
\hline SMPABC011 & 0.2186 & 0.0029 & 17.75 & 0.21 & 0.5877 & 0.0055 & 0.79 & 2980 & 22 & 2976 & 11 & 2971 & 21 & 100 \\
\hline SMPABC063 & 0.2202 & 0.0041 & 17.55 & 0.30 & 0.5781 & 0.0053 & 0.54 & 2941 & 22 & 2966 & 16 & 2982 & 30 & 99 \\
\hline SMPABC056 & 0.2185 & 0.0035 & 17.3 & 0.24 & 0.5739 & 0.0048 & 0.60 & 2924 & 20 & 2952 & 13 & 2970 & 25 & 98 \\
\hline SMPABC025 & 0.2167 & 0.0024 & 17.14 & 0.14 & 0.5732 & 0.0041 & 0.88 & 2921 & 17 & 2943 & 8 & 2956 & 17 & 99 \\
\hline SMPABC024 & 0.2182 & 0.0029 & 17.24 & 0.19 & 0.5722 & 0.0047 & 0.75 & 2917 & 19 & 2948 & 10 & 2968 & 21 & 98 \\
\hline SMPABC019 & 0.2183 & 0.0024 & 17.22 & 0.15 & 0.5713 & 0.0041 & 0.84 & 2913 & 17 & 2947 & 8 & 2968 & 18 & 98 \\
\hline SMPABC023 & 0.2162 & 0.0024 & 17.03 & 0.14 & 0.5710 & 0.0041 & 0.87 & 2912 & 17 & 2937 & 8 & 2952 & 18 & 99 \\
\hline SMPABC012 & 0.2161 & 0.0024 & 16.99 & 0.15 & 0.5696 & 0.0043 & 0.88 & 2906 & 18 & 2934 & 8 & 2952 & 18 & 98 \\
\hline SMPABC026 & 0.2171 & 0.0024 & 17.05 & 0.14 & 0.5688 & 0.0041 & 0.85 & 2903 & 17 & 2937 & 8 & 2959 & 18 & 98 \\
\hline SMPABC058 & 0.2158 & 0.0044 & 16.91 & 0.32 & 0.5682 & 0.0059 & 0.55 & 2900 & 24 & 2930 & 18 & 2949 & 33 & 98 \\
\hline SMPABC015 & 0.2152 & 0.0023 & 16.84 & 0.13 & 0.5670 & 0.0041 & 0.91 & 2896 & 17 & 2926 & 8 & 2945 & 17 & 98 \\
\hline SMPABC018 & 0.2187 & 0.0024 & 17.09 & 0.14 & 0.5661 & 0.0042 & 0.89 & 2892 & 17 & 2940 & 8 & 2971 & 17 & 97 \\
\hline SMPABC042 & 0.2157 & 0.0028 & 16.82 & 0.18 & 0.5650 & 0.0042 & 0.70 & 2887 & 17 & 2924 & 10 & 2949 & 21 & 98 \\
\hline SMPABC044 & 0.2166 & 0.0029 & 16.84 & 0.19 & 0.5634 & 0.0045 & 0.71 & 2881 & 18 & 2926 & 11 & 2955 & 21 & 97 \\
\hline SMPABC031 & 0.2141 & 0.0023 & 16.54 & 0.14 & 0.5597 & 0.0041 & 0.89 & 2865 & 17 & 2909 & 8 & 2937 & 17 & 98 \\
\hline
\end{tabular}


Table 4.3. (Continued).

\begin{tabular}{|c|c|c|c|c|c|c|c|c|c|c|c|c|c|c|}
\hline \multirow{2}{*}{$\begin{array}{c}\text { Sample } \\
\text { TF14-XII-178 } \\
\text { Spot number }\end{array}$} & \multicolumn{7}{|c|}{ Isotopic ratios } & \multicolumn{7}{|c|}{ Ages (Ma) } \\
\hline & ${ }^{207} \mathrm{~Pb} /{ }^{206} \mathrm{~Pb}$ & $\pm 1 \sigma$ & ${ }^{207} \mathrm{~Pb} /{ }^{235} \mathrm{U}$ & $\pm 1 \sigma$ & ${ }^{206} \mathbf{P b} /{ }^{238} \mathrm{U}$ & $\pm 1 \sigma$ & Rho & ${ }^{206} \mathrm{~Pb} /{ }^{238} \mathrm{U}$ & $\pm 1 \sigma$ & ${ }^{207} \mathrm{~Pb} /{ }^{235} \mathrm{U}$ & $\pm 1 \sigma$ & ${ }^{206} \mathrm{~Pb} /{ }^{207} \mathrm{~Pb}$ & $\pm 1 \sigma$ & Conc. \\
\hline SMPABC 010 & 0.2138 & 0.0023 & 16.52 & 0.13 & 0.5596 & 0.0041 & 0.91 & 2865 & 17 & 2907 & 8 & 2935 & 17 & 98 \\
\hline SMPABC062 & 0.2168 & 0.0037 & 16.7 & 0.26 & 0.5583 & 0.0050 & 0.58 & 2860 & 21 & 2918 & 15 & 2957 & 27 & 97 \\
\hline SMPABC 030 & 0.2146 & 0.0024 & 16.54 & 0.15 & 0.5582 & 0.0042 & 0.87 & 2859 & 18 & 2908 & 8 & 2941 & 18 & 97 \\
\hline SMPABC046 & 0.2151 & 0.0029 & 16.56 & 0.19 & 0.5576 & 0.0047 & 0.75 & 2857 & 20 & 2910 & 11 & 2945 & 21 & 97 \\
\hline SMPABC057 & 0.2147 & 0.0024 & 16.47 & 0.15 & 0.5558 & 0.0041 & 0.82 & 2849 & 17 & 2905 & 9 & 2941 & 18 & 97 \\
\hline SMPABC027 & 0.2162 & 0.0025 & 16.53 & 0.15 & 0.5539 & 0.0042 & 0.84 & 2841 & 17 & 2908 & 9 & 2952 & 19 & 96 \\
\hline SMPABC059 & 0.2151 & 0.0026 & 16.13 & 0.16 & 0.5435 & 0.0043 & 0.78 & 2798 & 18 & 2885 & 10 & 2944 & 20 & 95 \\
\hline SMPABC054 & 0.2126 & 0.0028 & 15.9 & 0.18 & 0.5418 & 0.0046 & 0.77 & 2791 & 19 & 2871 & 11 & 2926 & 21 & 95 \\
\hline SMPABC014 & 0.2111 & 0.0023 & 15.77 & 0.14 & 0.5414 & 0.0041 & 0.86 & 2790 & 17 & 2863 & 8 & 2914 & 18 & 96 \\
\hline SMPABC049 & 0.2137 & 0.0044 & 15.94 & 0.30 & 0.5411 & 0.0058 & 0.57 & 2788 & 24 & 2873 & 18 & 2934 & 33 & 95 \\
\hline SMPABC028 & 0.2131 & 0.0025 & 15.69 & 0.14 & 0.5333 & 0.0040 & 0.84 & 2755 & 17 & 2858 & 9 & 2929 & 19 & 94 \\
\hline SMPABC055 & 0.2140 & 0.0039 & 15.69 & 0.26 & 0.5322 & 0.0054 & 0.61 & 2751 & 23 & 2858 & 16 & 2936 & 29 & 94 \\
\hline SMPABC032 & 0.2112 & 0.0027 & 15.46 & 0.16 & 0.5302 & 0.0042 & 0.75 & 2742 & 18 & 2844 & 10 & 2915 & 21 & 94 \\
\hline SMPABC016 & 0.2129 & 0.0039 & 15.51 & 0.26 & 0.5280 & 0.0063 & 0.72 & 2733 & 27 & 2847 & 16 & 2928 & 29 & 93 \\
\hline SMPABC061 & 0.2141 & 0.0035 & 15.58 & 0.23 & 0.5271 & 0.0050 & 0.64 & 2729 & 21 & 2851 & 14 & 2937 & 26 & 93 \\
\hline SMPABC043 & 0.2121 & 0.0042 & 14.94 & 0.28 & 0.5104 & 0.0058 & 0.62 & 2659 & 25 & 2811 & 18 & 2922 & 32 & 91 \\
\hline SMPABC045 & 0.2108 & 0.0029 & 14.65 & 0.17 & 0.5038 & 0.0041 & 0.70 & 2630 & 17 & 2793 & 11 & 2911 & 22 & 90 \\
\hline SMPABC060 & 0.2083 & 0.0026 & 14.02 & 0.15 & 0.4876 & 0.0039 & 0.74 & 2560 & 17 & 2751 & 10 & 2892 & 20 & 89 \\
\hline SMPABC041 & 0.1941 & 0.0021 & 7.987 & 0.07 & 0.2981 & 0.0021 & 0.84 & 1682 & 11 & 2230 & 8 & 2777 & 18 & 61 \\
\hline SMPABC048 & 0.1700 & 0.0019 & 6.202 & 0.05 & 0.2643 & 0.0019 & 0.85 & 1512 & 10 & 2005 & 7 & 2558 & 18 & 59 \\
\hline SMPABC013 & 0.1818 & 0.0019 & 5.882 & 0.05 & 0.2343 & 0.0017 & 0.90 & 1357 & 9 & 1959 & 7 & 2670 & 18 & 51 \\
\hline SMPABC047 & 0.1697 & 0.0021 & 5.47 & 0.06 & 0.2335 & 0.0018 & 0.74 & 1353 & 9 & 1896 & 9 & 2555 & 21 & 53 \\
\hline
\end{tabular}


Table 4.4. Summary of U-Pb zircon data of sample PFG-CA-004A (metadiorite of the Serra de Santa Rita greenstone belt) obtained by LA-SF-ICP-MS method.

\begin{tabular}{|c|c|c|c|c|c|c|c|c|c|c|c|c|c|c|}
\hline \multirow{2}{*}{$\begin{array}{c}\text { Sample } \\
\text { PFG-CA-004A } \\
\text { Spot number }\end{array}$} & \multicolumn{7}{|c|}{ Isotopic ratios } & \multicolumn{7}{|c|}{ Ages (Ma) } \\
\hline & ${ }^{207} \mathrm{~Pb} /{ }^{206} \mathrm{~Pb}$ & $\pm 1 \sigma$ & ${ }^{207} \mathrm{~Pb} /{ }^{235} \mathbf{U}$ & $\pm 1 \sigma$ & ${ }^{206} \mathrm{~Pb} /{ }^{238} \mathbf{U}$ & $\pm 1 \sigma$ & Rho & ${ }^{206} \mathrm{~Pb} /{ }^{238} \mathrm{U}$ & $\pm 1 \sigma$ & ${ }^{207} \mathrm{~Pb} /{ }^{235} \mathrm{U}$ & $\pm 1 \sigma$ & ${ }^{206} \mathrm{~Pb} /{ }^{207} \mathrm{~Pb}$ & $\pm 1 \sigma$ & Conc. \\
\hline SMPABC049 & 0.20 & 0.00 & 22.77 & 0.31 & 0.833 & 0.008 & 0.68 & 3906 & 27 & 3217 & 13 & 2811 & 24 & 139 \\
\hline SMPABC041 & 0.20 & 0.00 & 20.44 & 0.29 & 0.733 & 0.007 & 0.73 & 3546 & 28 & 3113 & 14 & 2842 & 25 & 125 \\
\hline SMPABC027 & 0.22 & 0.00 & 18.29 & 0.35 & 0.591 & 0.008 & 0.7 & 2995 & 32 & 3005 & 18 & 3011 & 32 & 99 \\
\hline SMPABC063 & 0.22 & 0.01 & 17.61 & 0.37 & 0.585 & 0.007 & 0.54 & 2969 & 27 & 2969 & 20 & 2970 & 37 & 100 \\
\hline SMPABC016 & 0.21 & 0.00 & 16.90 & 0.21 & 0.587 & 0.006 & 0.78 & 2977 & 23 & 2929 & 12 & 2894 & 22 & 103 \\
\hline SMPABC023 & 0.21 & 0.00 & 16.97 & 0.16 & 0.582 & 0.005 & 0.83 & 2956 & 19 & 2933 & 9 & 2916 & 19 & 101 \\
\hline SMPABC030 & 0.21 & 0.00 & 17.01 & 0.14 & 0.581 & 0.004 & 0.88 & 2952 & 18 & 2935 & 8 & 2922 & 18 & 101 \\
\hline SMPABC019 & 0.21 & 0.00 & 16.89 & 0.16 & 0.581 & 0.005 & 0.81 & 2951 & 19 & 2928 & 9 & 2911 & 19 & 101 \\
\hline SMPABC056 & 0.21 & 0.00 & 16.91 & 0.16 & 0.580 & 0.004 & 0.79 & 2947 & 18 & 2930 & 9 & 2915 & 19 & 101 \\
\hline SMPABC043 & 0.21 & 0.00 & 16.88 & 0.15 & 0.579 & 0.004 & 0.85 & 2944 & 18 & 2928 & 9 & 2916 & 18 & 101 \\
\hline SMPABC017 & 0.21 & 0.00 & 16.87 & 0.14 & 0.579 & 0.004 & 0.91 & 2944 & 18 & 2927 & 8 & 2916 & 17 & 101 \\
\hline SMPABC026 & 0.21 & 0.00 & 16.97 & 0.17 & 0.579 & 0.005 & 0.81 & 2943 & 20 & 2933 & 10 & 2925 & 19 & 101 \\
\hline SMPABC053 & 0.21 & 0.00 & 16.90 & 0.16 & 0.578 & 0.004 & 0.8 & 2942 & 18 & 2929 & 9 & 2918 & 19 & 101 \\
\hline SMPABC032 & 0.21 & 0.00 & 16.92 & 0.16 & 0.578 & 0.005 & 0.86 & 2940 & 19 & 2930 & 9 & 2922 & 18 & 101 \\
\hline SMPABC031 & 0.21 & 0.00 & 16.87 & 0.15 & 0.577 & 0.004 & 0.87 & 2938 & 18 & 2928 & 8 & 2919 & 18 & 101 \\
\hline SMPABC040 & 0.21 & 0.00 & 16.77 & 0.16 & 0.577 & 0.005 & 0.82 & 2935 & 19 & 2922 & 9 & 2911 & 19 & 101 \\
\hline SMPABC013 & 0.21 & 0.00 & 16.78 & 0.14 & 0.576 & 0.004 & 0.89 & 2933 & 18 & 2922 & 8 & 2915 & 18 & 101 \\
\hline SMPABC050 & 0.21 & 0.00 & 16.92 & 0.18 & 0.576 & 0.005 & 0.78 & 2933 & 20 & 2930 & 10 & 2926 & 20 & 100 \\
\hline SMPABC051 & 0.21 & 0.00 & 16.89 & 0.17 & 0.576 & 0.005 & 0.79 & 2932 & 19 & 2929 & 10 & 2925 & 19 & 100 \\
\hline SMPABC060 & 0.21 & 0.00 & 16.74 & 0.17 & 0.576 & 0.005 & 0.77 & 2931 & 19 & 2920 & 10 & 2911 & 20 & 101 \\
\hline SMPABC014 & 0.21 & 0.00 & 16.90 & 0.14 & 0.574 & 0.004 & 0.92 & 2926 & 18 & 2929 & 8 & 2931 & 17 & 100 \\
\hline SMPABC055 & 0.21 & 0.00 & 16.82 & 0.16 & 0.574 & 0.005 & 0.82 & 2925 & 19 & 2925 & 9 & 2922 & 19 & 100 \\
\hline SMPABC018 & 0.21 & 0.00 & 16.76 & 0.14 & 0.573 & 0.004 & 0.91 & 2920 & 18 & 2921 & 8 & 2921 & 17 & 100 \\
\hline SMPABC042 & 0.21 & 0.00 & 16.76 & 0.15 & 0.573 & 0.004 & 0.84 & 2918 & 18 & 2921 & 9 & 2921 & 18 & 100 \\
\hline SMPABC037 & 0.21 & 0.00 & 16.73 & 0.15 & 0.572 & 0.004 & 0.87 & 2917 & 18 & 2920 & 8 & 2920 & 18 & 100 \\
\hline SMPABC054 & 0.21 & 0.00 & 16.75 & 0.17 & 0.571 & 0.005 & 0.8 & 2913 & 19 & 2921 & 10 & 2923 & 19 & 100 \\
\hline
\end{tabular}


Table 4.4. (Continued).

\begin{tabular}{|c|c|c|c|c|c|c|c|c|c|c|c|c|c|c|}
\hline \multirow{2}{*}{$\begin{array}{c}\begin{array}{c}\text { Sample } \\
\text { PFG-CA-004A }\end{array} \\
\text { Spot number }\end{array}$} & \multicolumn{7}{|c|}{ Isotopic ratios } & \multicolumn{7}{|c|}{ Ages (Ma) } \\
\hline & ${ }^{207} \mathrm{~Pb} /{ }^{206} \mathrm{~Pb}$ & $\pm 1 \sigma$ & ${ }^{207} \mathrm{~Pb} /{ }^{235} \mathrm{U}$ & $\pm 1 \sigma$ & ${ }^{206} \mathrm{~Pb} /{ }^{238} \mathrm{U}$ & $\pm 1 \sigma$ & Rho & ${ }^{206} \mathrm{~Pb} /{ }^{238} \mathrm{U}$ & $\pm 1 \sigma$ & ${ }^{207} \mathrm{~Pb} /{ }^{235} \mathrm{U}$ & $\pm 1 \sigma$ & ${ }^{206} \mathrm{~Pb} /{ }^{207} \mathrm{~Pb}$ & $\pm 1 \sigma$ & Conc. \\
\hline SMPABC062 & 0.21 & 0.00 & 16.68 & 0.17 & 0.571 & 0.004 & 0.76 & 2912 & 18 & 2917 & 10 & 2918 & 20 & 100 \\
\hline SMPABC044 & 0.21 & 0.00 & 16.66 & 0.16 & 0.568 & 0.005 & 0.83 & 2901 & 19 & 2915 & 9 & 2923 & 19 & 99 \\
\hline SMPABC010 & 0.21 & 0.00 & 16.67 & 0.17 & 0.565 & 0.005 & 0.83 & 2887 & 20 & 2916 & 10 & 2935 & 19 & 98 \\
\hline SMPABC052 & 0.21 & 0.00 & 16.60 & 0.25 & 0.563 & 0.006 & 0.66 & 2880 & 23 & 2912 & 14 & 2933 & 26 & 98 \\
\hline SMPABC024 & 0.21 & 0.00 & 16.54 & 0.14 & 0.562 & 0.004 & 0.9 & 2876 & 17 & 2909 & 8 & 2931 & 17 & 98 \\
\hline SMPABC061 & 0.21 & 0.00 & 16.47 & 0.16 & 0.562 & 0.004 & 0.78 & 2874 & 18 & 2904 & 9 & 2923 & 19 & 98 \\
\hline SMPABC048 & 0.21 & 0.00 & 16.48 & 0.16 & 0.561 & 0.004 & 0.83 & 2871 & 18 & 2905 & 9 & 2928 & 19 & 98 \\
\hline SMPABC039 & 0.21 & 0.00 & 16.46 & 0.14 & 0.560 & 0.004 & 0.87 & 2865 & 17 & 2904 & 8 & 2929 & 18 & 98 \\
\hline SMPABC038 & 0.21 & 0.00 & 16.36 & 0.15 & 0.557 & 0.004 & 0.86 & 2853 & 18 & 2898 & 9 & 2928 & 18 & 97 \\
\hline SMPABC028 & 0.21 & 0.00 & 16.30 & 0.16 & 0.556 & 0.005 & 0.85 & 2850 & 19 & 2894 & 9 & 2924 & 19 & 97 \\
\hline SMPABC015 & 0.21 & 0.00 & 15.70 & 0.14 & 0.533 & 0.004 & 0.88 & 2755 & 18 & 2859 & 9 & 2932 & 18 & 94 \\
\hline SMPABC036 & 0.21 & 0.00 & 15.66 & 0.24 & 0.531 & 0.005 & 0.65 & 2748 & 22 & 2856 & 15 & 2932 & 27 & 94 \\
\hline SMPABC059 & 0.21 & 0.00 & 15.46 & 0.14 & 0.528 & 0.004 & 0.8 & 2734 & 17 & 2844 & 9 & 2921 & 19 & 94 \\
\hline SMPABC011 & 0.21 & 0.00 & 15.47 & 0.14 & 0.528 & 0.004 & 0.9 & 2733 & 18 & 2845 & 8 & 2925 & 18 & 93 \\
\hline SMPABC029 & 0.21 & 0.00 & 15.31 & 0.13 & 0.525 & 0.004 & 0.89 & 2721 & 17 & 2835 & 8 & 2916 & 18 & 93 \\
\hline SMPABC025 & 0.21 & 0.00 & 15.27 & 0.14 & 0.520 & 0.004 & 0.86 & 2698 & 17 & 2832 & 8 & 2928 & 18 & 92 \\
\hline
\end{tabular}


Table 4.5. Summary of U-Pb zircon data of sample TF14-XII-183 (metatonalite of the Serra de Santa Rita greenstone belt) obtained by LA-SF-ICP-MS method.

\begin{tabular}{|c|c|c|c|c|c|c|c|c|c|c|c|c|c|c|}
\hline \multirow{2}{*}{$\begin{array}{c}\text { Sample } \\
\text { TF14-XII-183 } \\
\text { Spot number }\end{array}$} & \multicolumn{7}{|c|}{ Isotopic ratios } & \multicolumn{7}{|c|}{ Ages (Ma) } \\
\hline & ${ }^{207} \mathrm{~Pb} /{ }^{206} \mathrm{~Pb}$ & $\pm 1 \sigma$ & ${ }^{207} \mathrm{~Pb} /{ }^{235} \mathbf{U}$ & $\pm 1 \sigma$ & ${ }^{206} \mathrm{~Pb} /{ }^{238} \mathrm{U}$ & $\pm 1 \sigma$ & Rho & ${ }^{206} \mathrm{~Pb} /{ }^{238} \mathrm{U}$ & $\pm 1 \sigma$ & ${ }^{207} \mathrm{~Pb} /{ }^{235} \mathrm{U}$ & $\pm 1 \sigma$ & ${ }^{206} \mathrm{~Pb} /{ }^{207} \mathrm{~Pb}$ & $\pm 1 \sigma$ & Conc. \\
\hline SMPABC096 & 0.1384 & 0.0021 & 1.98 & 0.03 & 0.1041 & 0.0008 & 0.61 & 639 & 5 & 1109 & 9 & 2208 & 26 & 29 \\
\hline SMPABC091 & 0.1900 & 0.0020 & 10.64 & 0.09 & 0.4073 & 0.0031 & 0.91 & 2203 & 14 & 2492 & 8 & 2742 & 17 & 80 \\
\hline SMPABC090 & 0.1915 & 0.0020 & 11.27 & 0.09 & 0.4282 & 0.0033 & 0.92 & 2298 & 15 & 2546 & 8 & 2755 & 17 & 83 \\
\hline SMPABC089 & 0.1912 & 0.0020 & 12.33 & 0.10 & 0.4689 & 0.0036 & 0.92 & 2479 & 16 & 2630 & 8 & 2753 & 17 & 90 \\
\hline SMPABC088 & 0.1271 & 0.0014 & 2.03 & 0.02 & 0.1162 & 0.0009 & 0.90 & 709 & 5 & 1126 & 6 & 2059 & 19 & 34 \\
\hline SMPABC087 & 0.1885 & 0.0020 & 10.96 & 0.09 & 0.4230 & 0.0032 & 0.92 & 2274 & 15 & 2520 & 8 & 2729 & 17 & 83 \\
\hline SMPABC086 & 0.1688 & 0.0018 & 4.75 & 0.04 & 0.2045 & 0.0016 & 0.92 & 1200 & 8 & 1775 & 7 & 2545 & 18 & 47 \\
\hline SMPABC085 & 0.1750 & 0.0019 & 6.96 & 0.06 & 0.2892 & 0.0022 & 0.92 & 1638 & 11 & 2107 & 7 & 2606 & 17 & 63 \\
\hline SMPABC084 & 0.1418 & 0.0015 & 3.11 & 0.03 & 0.1596 & 0.0012 & 0.91 & 954 & 7 & 1435 & 6 & 2249 & 18 & 42 \\
\hline SMPABC083 & 0.1948 & 0.0021 & 12.32 & 0.10 & 0.4600 & 0.0035 & 0.92 & 2440 & 16 & 2629 & 8 & 2783 & 17 & 88 \\
\hline SMPABC082 & 0.1801 & 0.0019 & 6.50 & 0.05 & 0.2625 & 0.0020 & 0.92 & 1503 & 10 & 2046 & 7 & 2654 & 18 & 57 \\
\hline SMPABC074 & 0.0586 & 0.0007 & 0.82 & 0.01 & 0.1018 & 0.0008 & 0.75 & 625 & 5 & 608 & 5 & 551 & 27 & 113 \\
\hline SMPABC073 & 0.1834 & 0.0019 & 8.72 & 0.07 & 0.3455 & 0.0026 & 0.93 & 1913 & 13 & 2310 & 7 & 2684 & 17 & 71 \\
\hline SMPABC072 & 0.1891 & 0.0020 & 11.55 & 0.09 & 0.4438 & 0.0034 & 0.94 & 2368 & 15 & 2569 & 8 & 2734 & 17 & 87 \\
\hline SMPABC071 & 0.1937 & 0.0020 & 13.35 & 0.11 & 0.5006 & 0.0038 & 0.94 & 2616 & 16 & 2705 & 8 & 2774 & 17 & 94 \\
\hline SMPABC070 & 0.1731 & 0.0018 & 6.69 & 0.05 & 0.2805 & 0.0021 & 0.93 & 1594 & 11 & 2071 & 7 & 2588 & 17 & 62 \\
\hline SMPABC069 & 0.1919 & 0.0020 & 11.54 & 0.09 & 0.4369 & 0.0033 & 0.94 & 2337 & 15 & 2568 & 8 & 2758 & 17 & 85 \\
\hline SMPABC068 & 0.1449 & 0.0015 & 2.47 & 0.02 & 0.1239 & 0.0009 & 0.92 & 753 & 5 & 1264 & 6 & 2287 & 18 & 33 \\
\hline SMPABC067 & 0.1804 & 0.0019 & 8.27 & 0.07 & 0.3328 & 0.0025 & 0.94 & 1852 & 12 & 2261 & 7 & 2656 & 17 & 70 \\
\hline SMPABC066 & 0.1798 & 0.0019 & 8.90 & 0.07 & 0.3593 & 0.0028 & 0.93 & 1979 & 13 & 2328 & 8 & 2651 & 17 & 75 \\
\hline SMPABC065 & 0.1383 & 0.0015 & 2.62 & 0.02 & 0.1377 & 0.0010 & 0.93 & 831 & 6 & 1307 & 6 & 2207 & 18 & 38 \\
\hline SMPABC064 & 0.1819 & 0.0019 & 8.91 & 0.07 & 0.3556 & 0.0027 & 0.94 & 1961 & 13 & 2329 & 7 & 2670 & 17 & 73 \\
\hline SMPABC055 & 0.1333 & 0.0014 & 1.73 & 0.01 & 0.0940 & 0.0007 & 0.93 & 579 & 4 & 1019 & 5 & 2142 & 18 & 27 \\
\hline SMPABC054 & 0.1801 & 0.0018 & 8.56 & 0.07 & 0.3448 & 0.0026 & 0.96 & 1910 & 12 & 2292 & 7 & 2654 & 17 & 72 \\
\hline SMPABC053 & 0.1730 & 0.0018 & 4.77 & 0.04 & 0.2000 & 0.0015 & 0.94 & 1175 & 8 & 1780 & 7 & 2587 & 17 & 45 \\
\hline SMPABC052 & 0.1846 & 0.0019 & 9.70 & 0.08 & 0.3811 & 0.0029 & 0.96 & 2081 & 13 & 2406 & 7 & 2694 & 17 & 77 \\
\hline
\end{tabular}


Table 4.5. (Continued).

\begin{tabular}{|c|c|c|c|c|c|c|c|c|c|c|c|c|c|c|}
\hline \multirow{2}{*}{$\begin{array}{c}\text { Sample } \\
\text { TF14-XII-183 } \\
\text { Spot number }\end{array}$} & \multicolumn{7}{|c|}{ Isotopic ratios } & \multicolumn{7}{|c|}{ Ages (Ma) } \\
\hline & ${ }^{207} \mathrm{~Pb} /{ }^{206} \mathrm{~Pb}$ & $\pm 1 \sigma$ & ${ }^{207} \mathbf{P b} /{ }^{235} \mathbf{U}$ & $\pm 1 \sigma$ & ${ }^{206} \mathrm{~Pb} /{ }^{238} \mathrm{U}$ & $\pm 1 \sigma$ & Rho & ${ }^{206} \mathrm{~Pb} /{ }^{238} \mathrm{U}$ & $\pm 1 \sigma$ & ${ }^{207} \mathrm{~Pb} /{ }^{235} \mathrm{U}$ & $\pm 1 \sigma$ & ${ }^{206} \mathrm{~Pb} /{ }^{207} \mathrm{~Pb}$ & $\pm 1 \sigma$ & Conc. \\
\hline SMPABC051 & 0.1882 & 0.0020 & 9.30 & 0.07 & 0.3584 & 0.0027 & 0.95 & 1975 & 13 & 2368 & 7 & 2726 & 17 & 72 \\
\hline SMPABC050 & 0.1934 & 0.0020 & 12.29 & 0.10 & 0.4611 & 0.0035 & 0.96 & 2444 & 15 & 2627 & 7 & 2771 & 17 & 88 \\
\hline SMPABC049 & 0.1858 & 0.0019 & 7.86 & 0.06 & 0.3070 & 0.0024 & 0.95 & 1726 & 12 & 2216 & 7 & 2705 & 17 & 64 \\
\hline SMPABC048 & 0.1819 & 0.0019 & 8.57 & 0.07 & 0.3417 & 0.0026 & 0.94 & 1895 & 13 & 2294 & 7 & 2670 & 17 & 71 \\
\hline SMPABC047 & 0.1843 & 0.0019 & 8.12 & 0.06 & 0.3193 & 0.0024 & 0.96 & 1786 & 12 & 2244 & 7 & 2692 & 17 & 66 \\
\hline SMPABC046 & 0.1748 & 0.0018 & 7.21 & 0.06 & 0.2990 & 0.0023 & 0.96 & 1687 & 11 & 2138 & 7 & 2604 & 17 & 65 \\
\hline SMPABC039 & 0.0598 & 0.0007 & 0.84 & 0.01 & 0.1015 & 0.0008 & 0.78 & 623 & 5 & 618 & 5 & 595 & 26 & 105 \\
\hline SMPABC037 & 0.1926 & 0.0020 & 11.87 & 0.09 & 0.4464 & 0.0034 & 0.96 & 2379 & 15 & 2594 & 7 & 2764 & 17 & 86 \\
\hline SMPABC036 & 0.1863 & 0.0019 & 9.58 & 0.07 & 0.3725 & 0.0028 & 0.96 & 2041 & 13 & 2395 & 7 & 2710 & 17 & 75 \\
\hline SMPABC035 & 0.1842 & 0.0019 & 9.53 & 0.07 & 0.3746 & 0.0028 & 0.97 & 2051 & 13 & 2390 & 7 & 2691 & 17 & 76 \\
\hline SMPABC034 & 0.1794 & 0.0018 & 7.02 & 0.05 & 0.2834 & 0.0021 & 0.96 & 1608 & 11 & 2114 & 7 & 2648 & 17 & 61 \\
\hline SMPABC033 & 0.1782 & 0.0018 & 7.77 & 0.06 & 0.3157 & 0.0024 & 0.97 & 1769 & 12 & 2205 & 7 & 2636 & 17 & 67 \\
\hline SMPABC 032 & 0.1907 & 0.0019 & 12.20 & 0.09 & 0.4634 & 0.0035 & 0.97 & 2454 & 15 & 2620 & 7 & 2748 & 17 & 89 \\
\hline SMPABC031 & 0.1722 & 0.0018 & 6.88 & 0.05 & 0.2895 & 0.0022 & 0.97 & 1639 & 11 & 2096 & 7 & 2579 & 17 & 64 \\
\hline SMPABC030 & 0.1909 & 0.0019 & 12.10 & 0.09 & 0.4589 & 0.0034 & 0.97 & 2435 & 15 & 2612 & 7 & 2750 & 17 & 89 \\
\hline SMPABC029 & 0.1726 & 0.0018 & 5.85 & 0.05 & 0.2453 & 0.0018 & 0.97 & 1414 & 9 & 1954 & 7 & 2583 & 17 & 55 \\
\hline SMPABC028 & 0.1804 & 0.0018 & 7.94 & 0.06 & 0.3188 & 0.0024 & 0.97 & 1784 & 12 & 2225 & 7 & 2656 & 17 & 67 \\
\hline SMPABC019 & 0.1797 & 0.0018 & 8.72 & 0.07 & 0.3511 & 0.0026 & 0.97 & 1940 & 12 & 2310 & 7 & 2650 & 17 & 73 \\
\hline SMPABC018 & 0.1798 & 0.0018 & 8.05 & 0.06 & 0.3237 & 0.0024 & 0.97 & 1808 & 12 & 2236 & 7 & 2651 & 17 & 68 \\
\hline SMPABC017 & 0.1971 & 0.0020 & 14.04 & 0.11 & 0.5150 & 0.0039 & 0.97 & 2678 & 16 & 2752 & 7 & 2803 & 17 & 96 \\
\hline SMPABC016 & 0.1815 & 0.0018 & 8.80 & 0.07 & 0.3508 & 0.0026 & 0.97 & 1938 & 12 & 2318 & 7 & 2666 & 17 & 73 \\
\hline
\end{tabular}


Table 4.5. (Continued).

\begin{tabular}{|c|c|c|c|c|c|c|c|c|c|c|c|c|c|c|}
\hline \multirow{2}{*}{$\begin{array}{c}\begin{array}{c}\text { Sample } \\
\text { TF14-XII-183 }\end{array} \\
\text { Spot number }\end{array}$} & \multicolumn{7}{|c|}{ Isotopic ratios } & \multicolumn{7}{|c|}{ Ages (Ma) } \\
\hline & ${ }^{207} \mathrm{~Pb} /{ }^{206} \mathrm{~Pb}$ & $\pm 1 \sigma$ & ${ }^{207} \mathbf{P b} /{ }^{235} \mathbf{U}$ & $\pm 1 \sigma$ & ${ }^{206} \mathrm{~Pb} /{ }^{238} \mathrm{U}$ & $\pm 1 \sigma$ & Rho & ${ }^{206} \mathbf{P b} /{ }^{238} \mathbf{U}$ & $\pm 1 \sigma$ & ${ }^{207} \mathrm{~Pb} /{ }^{235} \mathrm{U}$ & $\pm 1 \sigma$ & ${ }^{206} \mathrm{~Pb} /{ }^{207} \mathrm{~Pb}$ & $\pm 1 \sigma$ & Conc. \\
\hline SMPABC015 & 0.1955 & 0.0020 & 12.93 & 0.10 & 0.4785 & 0.0036 & 0.98 & 2521 & 16 & 2675 & 7 & 2789 & 17 & 90 \\
\hline SMPABC014 & 0.1969 & 0.0020 & 13.73 & 0.11 & 0.5043 & 0.0038 & 0.97 & 2632 & 16 & 2731 & 7 & 2801 & 17 & 94 \\
\hline SMPABC013 & 0.1891 & 0.0020 & 10.33 & 0.08 & 0.3952 & 0.0030 & 0.96 & 2147 & 14 & 2465 & 7 & 2734 & 17 & 79 \\
\hline SMPABC012 & 0.1931 & 0.0020 & 12.91 & 0.10 & 0.4835 & 0.0036 & 0.97 & 2542 & 16 & 2673 & 7 & 2769 & 17 & 92 \\
\hline SMPABC011 & 0.1969 & 0.0020 & 13.75 & 0.11 & 0.5051 & 0.0038 & 0.96 & 2636 & 16 & 2733 & 7 & 2800 & 17 & 94 \\
\hline SMPABC010 & 0.1792 & 0.0019 & 7.90 & 0.06 & 0.3189 & 0.0024 & 0.95 & 1784 & 12 & 2220 & 7 & 2645 & 17 & 67 \\
\hline
\end{tabular}

\subsection{Summary of whole rock Sm-Nd isotopic analytical data}

Table 5. Sm-Nd isotopic data of metavolcanic and metaplutonic rocks of the Serra de Santa Rita greenstone belt.

\begin{tabular}{|c|c|c|c|c|c|c|c|c|}
\hline Sample & Nd (ppm) & Sm (ppm) & ${ }^{147} \mathrm{Sm} /{ }^{144} \mathrm{Nd}$ & ${ }^{143} \mathrm{Nd} /{ }^{144} \mathrm{Nd} \pm 2 \sigma$ & ENd (0) & $\mathbf{t}(\mathrm{Ma})$ & $\varepsilon N d(t)$ & $T_{D M}(\mathbf{G a})$ \\
\hline TF14-XII-178 (Amphibolite) & 3.751 & 17.629 & 0.1286 & $0.511418 \pm 4$ & -23.80 & 2959 & 2.18 & 3.08 \\
\hline PFG-CA-004A (Metadiorite) & 7.380 & 38.469 & 0.1160 & $0.511192 \pm 4$ & -28.22 & 2920 & 2.16 & 3.03 \\
\hline PFG-CA-004E (Metadiorite) & 4.654 & 25.205 & 0.1116 & $0.511137 \pm 3$ & -29.27 & 2920 & 2.77 & 2.99 \\
\hline TF14-XII-183 (Metatonalite) & 2.729 & 14.023 & 0.1176 & $0.511164 \pm 10$ & -28.74 & 2790 & -0.30 & 3.13 \\
\hline
\end{tabular}


CAPÍTULO III - CONSIDERACÕES FINAIS 
A realização de estudos em terrenos arqueanos como os greenstone belts é um grande desafio devido à elevada complexidade geológica envolvida na evolução destes terrenos que carregam o registro de múltiplos estágios de magmatismo, metamorfismo, deformação, metassomatismo e alteração hidrotermal. Tais fatores dificultam o reconhecimento da composição química primária dos diferentes tipos de rocha e da estratigrafia original das sequências supracrustais. Em regiões tropicais como o Brasil, dificuldades adicionais podem estar presentes em razão da escassez de afloramentos em algumas áreas e ao estado de preservação das rochas que muitas vezes é bastante afetado pelo intemperismo químico.

A par de todas as dificuldades, os resultados obtidos nestes estudos são extremamente importantes por fornecerem informações valiosas da dinâmica da Terra durante o Arqueano e por abrir novas visões que permitem correlações com processos geológicos modernos. Os greenstone belts arqueanos carregam o registro dos diversos tipos de magmatismo ocorridos na Terra primitiva e, portanto, a determinação dos ambientes tectônicos envolvidos na formação destas sequências é fundamental para a compreensão de como os crátons arqueanos foram construídos e amalgamados. A importância econômica destes terrenos também deve ser destacada, tendo em vista que o Arqueano é o Éon mais mineralizado do registro geológico.

Neste sentido, esta dissertação de mestrado contribuiu para uma melhor caracterização dos greenstone belts Faina e Serra de Santa Rita e para um melhor entendimento da evolução do Terreno Arqueano-Paleoproterozóico de Goiás. Os principais pontos a serem destacados são:

\section{Distribuição espacial das rochas metavulcânicas e metaplutônicas}

O mapeamento geológico realizado junto ao Projeto Faina-Goiás (TF-2014 do Instituto de Geociências da Universidade de Brasília) mostrou que as rochas metavulcânicas são mais abundantes no greenstone belt Serra Santa Rita e na porção norte do greenstone belt Faina e possuem composição predominantemente ultramáfica. As rochas máficas correspondem a anfibólitos restritos ao greenstone belt Serra Santa Rita e estão associadas à lentes de metandesito e intrusões dioríticas a tonalíticas poli-deformadas. 


\section{Os protólitos}

A determinação dos protólitos das rochas foi realizada a partir de observações diretas de campo associadas aos estudos petrográficos e geoquímicos. As pillow lavas mapeadas em rochas ultramáficas do greenstone belt Serra de Santa Rita mostram que estas rochas representam derrames de lavas ultramáficas em ambiente subaquoso. Texturas ígneas primárias estão localmente preservadas nos anfibolitos, que são interpretados como metabasaltos, e nos metandesitos, metadioritos e metatonalitos. Estas texturas primárias preservadas incluem domínios com textura porfirítica e textura intergranular.

\section{Metamorfismo}

As paragêneses minerais presentes nos anfibolitos, metadioritos e em algumas rochas ultramáficas indicam que o pico metamórfico na região atingiu fácies anfibolito. A presença de minerais de baixo grau metamórfico, que substituem as fases diagnósticas do metamorfismo em fácies anfibolito, caracteriza um retrometamorfismo em fácies xisto verde. As sequências metassedimentares dos greenstone belts Faina e Serra de Santa Rita apresentam apenas as paragêneses do metamorfismo em fácies xisto verde. Tal situação sugere que o metamorfismo em fácies anfibolito que afetou as rochas metavulcânicas e metaplutônicas basais dos greenstone belts Faina e Serra de Santa Rita ocorreu no Arqueano. As rochas sedimentares destes greenstone belts só foram depositadas no Paleoproterozóico e por isso registram apenas o metamorfismo em fácies xisto verde, resultado de outro evento termo-tectônico mais tardio.

\section{Assinaturas geoquímicas e ambiente tectônico}

As assinaturas geoquímicas das rochas metavulcânicas e metaplutônicas dos greenstone belts Faina e Serra de Santa Rita foram utilizadas principalmente para a obtenção de informações a respeito do ambiente tectônico destas rochas. Algumas rochas ultramáficas apresentam semelhanças com boninitos que incluem os baixos teores de $\mathrm{TiO}_{2}(<0.5 \%)$, padrões de ETR em formato de "U" e anomalias negativas de $\mathrm{Nb}$ e Ti. Alguns komatiitos com assinaturas geoquímicas semelhantes aos boninitos ocorrem em outros greenstone belts arqueanos e são interpretados como derrames extrudidos em ambiente de forearc nos estágios iniciais de desenvolvimento de arcos intraoceânicos, de maneira análoga aos boninitos modernos (e.g. Parman et al., 2001, 2004; Parman and Grove, 2004). 
Os anfibolitos podem ser divididos em dois grupos com base nos elementos traço: basaltos do tipo 1 e basaltos do tipo 2. Os basaltos do tipo 1 são toleíticos e se assemelham com basaltos de bacias de back-arc $(B A B B)$. Os basaltos do tipo 2 são mais enriquecidos e apresentam elevados teores de $\mathrm{Nb}$, comparáveis aos basaltos enriquecidos em $\mathrm{Nb}(\mathrm{Nb}$ enriched basalts; NEB). Os metandesitos e metatonalitos apresentam similaridades com adakitos de alta-sílica (high-silica adakites; HSA), enquanto os metadioritos possuem teores de $\mathrm{MgO}, \mathrm{Cr}$ e Ni muito elevados e se assemelham mais com adakitos de baixa-sílica (lowsilica adakites; LSA) ou andesitos magnesianos (high-Mg andesites; HMA). A associação entre $\mathrm{Nb}$-enriched basalts, adakitos e high-Mg andesites ocorrem em zonas de subducção quentes fanerozóicas, onde a fusão parcial da placa oceânica subductada é possível (Defant et al., 1992; Kepezhinskas et al., 1996; Sajona et al., 1996; Aguillon-Robles et al., 2001; Wang et al., 2007). Estas associações também já foram descritas em vários greenstone belts arqueanos (e.g. Hollings and Kerrich, 2000; Wyman et al., 2000; Polat and Kerrich, 2001; Hollings, 2002; Shchipansky et al., 2004; Manikyamba and Khanna, 2007; Manikyamba et al., 2007; Kerrich and Manikyamba, 2012). Deste modo, é bastante sugestiva a interpretação de que os protólitos das rochas metavulcânicas e metaplutônicas que formam os greenstone belts Faina e Serra de Santa foram gerados em um ambiente de subducção semelhante aos reportados para a ocorrência de $\mathrm{Nb}$-enriched basalts, adakitos e high-Mg andesites.

\section{Geocronologia U-Pb e isótopos de Sm-Nd}

Os dados U-Pb em zircão apresentados neste trabalho mostram que as sequências metavulcânicas dos greenstone belts Faina e Serra de Santa Rita são do Mesoarqueano (2,96 $\mathrm{Ga}$; idade U-Pb do anfibolito correspondente aos basaltos do tipo 2 do greenstone belt Serra de Santa Rita). A sequência metavulcânica foi intrudida por corpos dioríticos em torno de 2,92 Ga. Intrusões menores de tonalito ocorreram por volta de 2,79 Ga. Duas amostras de cloritito foram datadas, um deles localizado no greenstone belt Faina e o outro localizado no

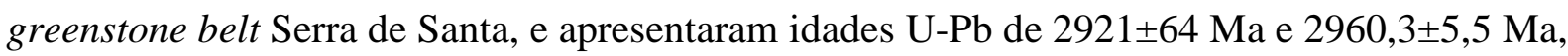
respectivamente. Tais idades são semelhantes às idades obtidas para as amostras de anfibolito e metadiorito, respectivamente. Em síntese, os dados mostram dois períodos principais de atividade magmática: 2,96-2,92 Ga e 2,79 Ga.

Os dados Sm-Nd em rocha total revelaram que o anfibolito (correspondente aos basaltos do tipo 2) e os metadioritos analisados apresentam $\mathrm{T}_{\mathrm{DM}}$ entre 3,08 e 2,99 Ga e valores iniciais de $\varepsilon_{\varepsilon d}$ entre 2,16-2,77. O metatonalito intrusivo no greenstone belt Serra de Santa Rita 
apresentou $\mathrm{T}_{\mathrm{DM}}$ de 3,13 Ga e eNd inicial igual a -0,30. Tais dados indicam uma assinatura juvenil para os magmas que deram origem aos derrames basálticos e às intrusões dioríticas e não indicam a presença de contaminação com crosta continental mais antiga nestas rochas. As intrusões tonalíticas tardias, por outro lado, indicam a influência de contaminação de uma crosta continental de idade em torno de 3,13 Ga.

\section{Modelo geodinâmico}

Com a integração dos dados obtidos foi possível sugerir um modelo geodinâmico para os greenstone belts Faina e Serra de Santa. O conjunto está inserido num sistema forearc-arcback-arc intraoceânico. O estágio inicial corresponde à extrusão de lavas ultramáficas em ambiente de forearc em torno de 2,96 Ga, de maneira análoga aos boninitos fanerozóicos, porém sob taxas de fusão do manto mais elevadas no Arqueano. A progressão da subducção possibilitou a fusão parcial da placa oceânica subductada e geração de adakitos (metandesitos do greenstone belt Serra de Santa Rita). A fusão parcial do manto residual que foi metassomatizado com magma adakítico e enriquecido em $\mathrm{Nb}$ gerou os basaltos enriquecidos em $\mathrm{Nb}$ (anfibolitos do grupo dos basaltos do tipo 2 do greenstone belt Serra de Santa Rita). A fusão por descompressão na região de back-arc gerou os derrames de basaltos toleíticos (anfibolitos do grupo dos basaltos do tipo 1 do greenstone belt Serra de Santa Rita).

Em torno de 2,92 Ga, o magma adakitico foi totalmente metassomatizado pelo manto peridotítico e a posterior fusão deste manto metassomatizado gerou magmatismo andesítico com altos teores de $\mathrm{MgO}, \mathrm{Cr}$ e $\mathrm{Ni}$, que se alojou na crosta como intrusões dioríticas (metadioritos do greenstone belt Serra de Santa Rita). O estágio final corresponde à formação de arco continental em aproximadamente 2,79 Ga, marcado por geração de magmatismo tonalítico e amalgamação com outros arcos de ilhas e arcos continentais que constituem os complexos TTG Uvá e Caiçara para formar o substrato arqueano da porção sul do Terreno Arqueano-Paleoproterozóico de Goiás. Estas interpretações são coerentes com a atuação da tectônica de placas durante o Mesoarqueano.

\section{Sugestões para trabalhos futuros}

A interpretação do modelo geodinâmico dos greenstone belts Faina e Serra de Santa Rita apresentada neste trabalho foi possível com a integração dos dados. No entanto, para um melhor desenvolvimento do modelo, devem-se ampliar a quantidade de dados geoquímicos e geocronológicos, principalmente. É importante obter a idade exata das rochas ultramáficas, 
dos anfibolitos que correspondem aos basaltos toleíticos do tipo 1, interpretados como basaltos de back-arc, e dos metandesitos do greenstone belt Serra de Santa Rita para verificação se estas rochas estão realmente temporalmente associadas.

É importante um melhor refinamento na caracterização geoquímica das rochas ultramáficas dos greenstone belts Faina e Serra de Santa Rita com uma maior quantidade de dados provenientes de amostras bem preservadas, com o intuito de obter uma determinação mais segura do ambiente tectônico no qual estas rochas foram geradas. Estudos geoquímicos semelhantes também são importantes nas rochas metavulcânicas dos greenstone belts Crixás, Guarinos e Pilar de Goiás, com o intuito de verificar se as assembleias de rochas relacionadas aos arcos magmáticos, reconhecidas nos greenstone belts Faina e Serra de Santa Rita, também ocorrem nos greenstone belts da porção norte do Terreno Arqueano-Paleoproterozóico de Goiás. A integração dos dados e interpretações apresentadas neste trabalho, com novos dados provenientes de estudos futuros na região irão ampliar progressivamente o conhecimento a cerca destes greenstone belts. 


\section{REFERÊNCIAS BIBLIOGRÁFICAS}

Adam, J., Green, T.H., Sie, S.H., 1993. Proton micropobe determined partitioning of Rb, Sr, $\mathrm{Ba}, \mathrm{Y}, \mathrm{Zr}, \mathrm{Nb}$ and $\mathrm{Ta}$ between experimentally produced amphiboles and silicicate melts with variable F content. Chemical Geology 109, 29-49.

Aguillón-Robles, A., Calmus, T., Benoit, M., Bellon, H., Maury, R.C., Cotton, J., Bourgois, J., Michard, F., 2001. Late Miocene adakites and Nb-enriched basalts from Vizcaino Peninsula, Mexico: indicators of East Pacific Rise subduction below Southern Baja California? Geology 29, 531-534.

Almeida, F.F.M., Hasui, Y., Brito Neves, B.B., Fuck, R.A., 1981. Brazilian structural provinces: na introduction. Earth-Science Reviews 17 (1), 1-29.

Anhaeusser, C.R., 2014. Archaean greenstone belts and associated granitic rocks - A review. Journal of African Earth Sciences 100, 684-732.

Araújo Filho, J.O., 2000. The Pirineus Syhntaxis: an example of the intersection of two Brasiliano foldthrust belts in central Brazil and its implications for the tectonic evolution of western Gondwana. Rev. Bras. Geociências 30, 144-148.

Arndt, N.T., Teixeira, N.A., White, W.M., 1989. Bizarre geochemistry of komatiites from the Crixás Greenstone Belt. Contribution to Mineralogy and Petrology 101, 187-197.

Arndt, N.T., 1994. Archaean komatiites. In: K.C. Condie (Ed.), Archaean Crustal Evolution. Elsevier, Amsterdam, pp. 11-44.

Arndt, N.T., Lesher, C.M., Barnes, S.-J., 2008. Komatiite. Cambridge University Press, 465 pp. Nature 362, 144-146.

Atherton, M.O., Petford, N., 1993. Generation of sodium-rich magmas from newly underplated basaltic crust.

Baêta Júnior, J.D.A., Oliveira, C. C., Pinheiro, M. M., Andrade, R. S., Camargo, M. A., 2000. Programa Levantamentos Geológicos Básicos do Brasil - Escala 1:100.000, Folha SD.22-ZC-V, Goiás. CPRM.

Beghelli Junior, L.P., 2012. Charnockitos e ortognaisses da porção centro-oeste do Bloco Arqueano de Goiás: Dados geoquímicos e isotópicos. Dissertação de Mestrado, Instituto de Geociências, Universidade de Brasília, Brasília, 87 pp.

Benn, K., Mareschal, J.-C., Condie, K.C., 2006. Introduction: Archean geodynamics and environments. In: Benn, K., Mareschal, J.-C, Condie, K.C. (Eds.), Archean Geodynamics and Environments, vol. 164. American Geophysical Union Geophysical Monograph, 4 pp.

Brant, R.A.P., Souza, V.S., Dantas, E.L., Jost, H., Rodrigues, V.G., Carvalho, M.J., Araújo, K.C., 2015. Contribuição ao estudo de proveniência sedimentar com base em dados U-Pb para o greenstone belt de Faina, Goiás. In: SBG, XIV Simpósio de Geologia do Centro-Oeste, Brasília, Anais, pp. 30-33. 
Brown, G.C., 1985. Processes and problems in the continental lithosphère: geological history and physical implications. In: Snelling, N. (Ed.), Geochronology and Geological Record, Special Publication - Geological Society of London 10, pp. 326-334.

Bühn, B., Pimentel, M.M., Matteini, M., Dantas, E., 2009. High spatial resolution analysis of $\mathrm{Pb}$ and $\mathrm{U}$ isotopes for geochronology by laser ablation multi-collector inductively coupled plasma mass spectrometry (LA-MC-ICP-MS). Anais da Academia Brasileira de Ciências 81 (1), 99-114.

Calvert, A.J., Sawyer, E.W., Davis, W.J., Luden, J.N., 1995. Archean subduction inferred from seismic images of a mantle suture in the Superior Province. Nature 375, 670-674.

Campbell, I.H., Griffiths, R.W., Hill, R.L., 1989. Melting in an Archaean mantle plume: heads its's basalts, tails it's komatiites. Nature 369, 697-699.

Carvalho, M.J., Rodrigues, V.G., Jost, H., 2013. Formação Arraial Dantas: Depósito aurífero detrítico glacígeno do greenstone belt de Faina, Goiás. In: UFRGS, Simpósio Brasileiro de Metalogenia, 3, Gramado.

Carrol, M.R., Wyllie, P.J., 1989. Experimental phase relations in the system tonaliteperidotite- $\mathrm{H}_{2} \mathrm{O}$ at $15 \mathrm{~kb}$ : implications for assimilation and differentiation processes near the crust-mantle bondary. Journal of Petrology 30, 1351-1382.

Castillo, P.R., Janney, P.E., Solidum, R.U., 1999. Petrology and geochemistry of Camiguin island., southern Philippines: insights to the source of adakites and other lavas in a complex arc setting. Contribution to Mineralogy and Petrology 134, 33-51.

Cawood, P.A., Kröner, A., Pisarevsky, S., 2006. Precambrian plate tectonics: criteria and evidence. GSA Today 16 (7), 4-11.

Condie, K.C., 1994. Greenstones through time. In: Condie, K.C. (Ed.), Archean Crustal Evolution. Elsevier, Amsterdam, pp. 85-121.

Condie, K.C., 2000. Episodic continental growth models: afterthoughts and extensions. Tectonophysics 322, 153-162.

Condie, K.C., 2005. TTGs and adakites: are they both slab melts? Lithos 80, 33-34.

Condie, K.C., Viljoen, M.J., Kable, E.J.D., 1977. Effects of alteration on element distributions in Archean tholeiites from the Barberton greenstone belt, South Africa. Contributions to Mineralogy and Petrology 64, 75-89.

Corrêa da Costa, P.C., 2003. Petrologia, geoquímica e geocronologia dos diques máficos da região de Crixás-Goiás, porção centro-oeste do Estado de Goiás. Tese de Doutorado, Instituto de Geociências, Universidade de São Paulo, 151 pp.

Crawford, A.J., Falloon, T.J. and Green, D.H., 1989. Classification, petrogenesis and tectonic setting of boninites. In: A.J. Crawford (Ed.), Boninites, Unwin Hyman, London, pp. 1-49. 
Danni, J.C.M \& Ribeiro, C.C., 1978. Caracterização Estratigráfica da Sequência Vulcanossedimentar de Pilar de Goiás e de Guarinos, Goiás. In: SBG, Congresso Brasileiro de Geologia, 30, Recife, Anais, v. 2, pp.582-596.

Danni, J.C.M., Dardenne, M.A., Fuck, R.A., 1981. Geologia da região da Serra da Santa Rita e Sequência Serra de Cantagalo. In: SBG, Simpósio de Geologia do Centro-Oeste, 1, Goiânia, Anais, pp. 265-280.

Danni, J.C.M., Jost, H., Winge, M., Andrade, G.F., 1986. Aspectos da evolução dos terrenos granito-greenstone belt: exemplo da região de Hidrolina, Goiás. In: SBG, Congresso Brasileiro de Geologia, 35, Goiânia, Anais, v. 2., pp. 570-584.

Defant, M.J., Drummond, M.S., 1990. Derivation of some modern arc magmas by melting of Young subducted lithosfere. Nature 347, 662-665.

Defant, M.J., Jackson, T.E., Drummond, M.S., De Boer, J.Z., Bellon, H., Feigenson, M.D., Maury, R.C., Stewart, R.H., 1992. The geochemistry of young volcanism throughout western Panama and southeastern Costa Rita: an overview. Journal of the Geological Society (London) 149, 569-579.

DellaGiustina, M.E.S., Oliveira, C.G., Pimentel, M., Buhn, B., 2009. Neoproterozoic magmatism and high-grade metamorphism in the Goiás Massif: new LA-MC-ICMPS U-Pb and Sm-Nd data and implications for collisional history of the Brasília Belt. Precambrian Research 172, 67-79.

De Paolo, D. J., 1981. Neodymium isotopes in the Colorado front range and crust-mantle evolution in the Proterozoic. Nature 291, 193-196.

De Wit, M.J., Hart, R.A., 1993. Earth's earliest continental lithosfere, hydrothermal flux and crustal recycling. Lithos 30, 309-335.

Dostal, J., Strong, D.F., Jamieson, R.A., 1980; Trace element mobility in the mylonite zone within the ophiolite aureole, St. Anthony Complex, Newfoundland. Earth and Planetary Science Letters 49, 188-192.

Dostal, J. and Mueller, W.U., 1997. Komatiite flooding of rifted Archean rhyolite arc complex: geochemical signature and tectonic significance of Stoughton-Roquemaire Group, Abitibi greenstone belt, Canada. Journal of Geology 105, 545-563.

Dostal, J. and Mueller, W.U., 2004. Komatiite geochemistry. In: Eriksson, P.G., Altermann, W., Nelson, D.R., Mueller, W.U. and Catuneamu, O. (Eds.), The Precambrian Earth: Tempos and Events. Elsevier, Amsterdam, pp. 290-298.

Floyd, P.A., 1989. Geochemical features of intraplate oceanic plateau basalts. In: Saunders, A.D., Norry, M.J. (Eds.), Magmatism in the Ocean Basins. Geol. Soc. Spec. Publ. London, 42, pp. 313-345. 
Fortes, P.T.F.O., 1996. Metalogênese dos depósitos auríferos Mina III, Mina Nova e Mina Inglesa, greenstone belt de Crixás, GO. Tese de Doutorado, Instituto de Geociências, Universidade de Brasília, 176 pp.

Fortes, P.T.F.O., Pimentel, M.M., Santos, R.V., Junges, S., 2003. Sm-Nd study of the Crixás greenstone belt, Brazil: implications for the age of deposition of the upper sedimentary rocks and associated Au mineralization. Journal of South American Earth Sciences 16, 503-512.

Ferreira Filho, C.F., Nilson A.A., Naldrett A.J., 1992. The Niquelândia mafic-ultramafic complex, Goiás, Brazil: A contribution to the ophiolite x stratiform controversy based on new geological and structural data. Precambrian Research 59, 125-143.

Ferreira-Filho, C.F., Kamo, S.L., Fuck, R.A., Krogh, T.E., Naldrett, A.J., 1994. Zircon and rutile $\mathrm{U} / \mathrm{Pb}$ geochronology of the Niquelândia layered mafic and ultramafic intrusion, Brazil: constraints for the timing of magmatism and high grade metamorphism. Precambrian Research 68 (3-4), 241-255.

Furnes, H., Dilek, Y., de Wit, M.J., 2015. Precambrian greenstone sequences represent different ophiolite types. Gondwana Research 27, 649-685.

Gao, S., Rudnick, R.L., Yuan, H.L., Liu, X.M., Liu, Y.S., Xu, W.L., Lin, W.L., Ayers, J., Wang, X.C., Wang, Q.H., 2004. Recycling lower continental crust in the North China craton. Nature 432, 892-897.

Gioia, S.M.C.L., Pimentel, M.M., 2000. The Sm-Nd isotopic method in the geochronology laboratory of the University of Brasília. Anais da Academia Brasileira de Ciências 72 (2), 19245.

Gutscher, M.-A., Spakman, W., Bijwaard, H., Engdahl, E.R., 2000. Geodynamics of flat subduction: seismicity and tomographic constraints from the Andean margin. Tectonics 19 (5), 814-833.

Hargraves, R.B., 1986. Faster spreading or greater ridge length in the Archaean. Geology 14, 750-752.

Hart, S.R., Erlank, A.J., Kable, E.J.D., 1974. Sea-floor basalt alteration: some chemical and isotopic effects. Contributions to Mineralogy and Petrology 44, 219-230.

Herzberg, C., 1992. Depth and degree of melting of komatiites. Journal of Geophysical Research 97, 4521-4540.

Hollings, P., 2002. Archean Nb-enriched basalts in the northern Superior Province. Lithos 64, $1-14$.

Hollings, P. and Kerrich, R., 2000. An Archean arc basalt-Nb-enriched basalt-adakite association: the $2.7 \mathrm{Ga}$ confederation assemblage of the Birch-Uchi greenstone belt, superior province. Contributions to Mineralogy and Petrology 139, 208-226. 
Howkesworth, C.J., Gallagher, K., Hergt, J.M., McDetmott, F., 1993. Mantle and slab contributions in arc magmas. Annual Review of Earth and Planetary Sciences 21, 175-204.

Jackson, S. E., Pearsona, N. J., Griffina, W.L., Belousova, E. A., 2004. The application of laser ablation-inductively coupled plasma-mass spectrometry to in situ $\mathrm{U}-\mathrm{Pb}$ zircon geochronology. Chemical Geology 211, 47-69.

Jahn, B.M., Glikson, A.Y., Peucat, J.-J., Hickman, A.H., 1981. REE geochemistry and isotopic data of Archaean silicic volcanics and granitoids from the Pilbara Block, western Australia: implications for the early crustal evolution. Geochimica et Cosmochimica Acta 45, 1633-1652.

Johnston, A.D. and Wyllie, P.J., 1989. The system tonalite-peridotite- $\mathrm{H}_{2} \mathrm{O}$ at $30 \mathrm{kbar}$, with applications to hydridization in subduction zone magmatism. Contribution to Mineralogy and Petrology 102, 257-264.

Jost, H. \& Oliveira, A.M., 1991. Stratigraphy of the greenstone belts, Crixás region, Goiás, Central Brazil. Journal of South American Earth Sciences 4, 201 -214.

Jost, H., Oliveira, A.M., Vargas, M.C., 1992. Petrography, geochemistry and structural control of trondhjemitic intrusions in greenstone belts of the Crixás region, Central Brazil. In: SBG, Congresso Brasileiro de Geologia, 37, São Paulo. Anais, v. 1. pp. 43-44.

Jost, H., Pimentel, M.M., Fuck, R.A., Danni, J.C., Heaman, L., 1993. Idade U-Pb do Diorito Posselândia, Hidrolina, Goiás. Revista Brasileira de Geociências 23, 352-355.

Jost, H., Kuyumjian, R.M., Freitas, A.L.S., Costa, A.L.L., Nascimento, C.T.C., Vasconcelos, F.M., Galotti, L., Martins, M.C.A., Carvalho, M.N., Condé, V.C., 1995. Geologia da porção norte do Greenstone Belt de Guarinos, GO. Revista Brasileira de Geociências 25, 51-60.

Jost, H., Fuck, R.A., Dantas, E.L., Rancan, C.C., Rezende, D.B., Santos, E., Portela, J.F., Mattos, L., Chiarini, M.F.N., Oliveira, R.C., Silva, S.E., 2005. Geologia e geocronologia do Complexo Uvá, Bloco Arqueano de Goiás. Revista Brasileira de Geociências 35, 559-572.

Jost, H., Dussin, I.A., Chemale Jr., F., Tassinari, C.C.G., Junges, S., 2008. U-Pb and Sm-Nd constraints for the Paleoproterozoic age of the metasedimentary sequences of the Goiás Archean greenstone belts. South Am. Symp. Isotope Geology, 6, San Carlos de Bariloche, Argentina, Proceedings, 4 pp.

Jost, H., Chemale Jr., F., Dussin, I.A., Tassinari, C.C.G., Martins, R., 2010. A U-Pb zircon Paleoproterozoic age for the metasedimentary host rocks and gold mineralization of the Crixás greenstone belt, Goiás, Central Brazil. Ore Geol. Reviews 37, 127-139.

Jost, H., Rodrigues, V.G., Carvalho, N.J., Chemale Jr., F., Marques, J.C., 2012. Estratigráfica e geocronologia do greenstone belt de Guarinos, Goiás. Geol. USP, Sér. cient., São Paulo 12 (2), 3-48.

Jost, H., Chemale Jr., F., Fuck, R.A., Dussin, R.A., 2013. Uvá complex, the oldest orthogneisses of the Archean Paleoproterozoic terrane of central Brazil. Journal of South American Earth Sciences 47, 201-212. 
Jost, H., Carvalho, M.J., Rodrigues, V.G., Martins, R., 2014. Metalogênese dos greenstone belts de Goiás. In: Silva, M.G., Neto, M.B.R., Jost, H., Kuyumjian, R.M. (Orgs.), Metalogênese das províncias tectônicas brasileiras, Belo Horizonte, CPRM, pp. 141-168.

Junges, S.L., Dantas, E.L., Pimentel, M.M., Laux, J.H., 2002. Idades U-Pb de granitos sin- a tardi-tectônicos do Arco Magmático de Mara Rosa, Goiás. SBG-Núcleo Nordeste, Congresso Brasileiro de Geologia, vol. 41. João Pessoa, Anais, pp. 312.

Junges, S.L., Pimentel, M.M., Dantas, E.L., Laux, J.H., 2003. New ID-TIMS U-Pb ages in the western portion of the Mara Rosa Arc: Two hundred million years of arc building. South American Symposium on the Isotope Geology, vol. 4. Salvador, Short Papaers 1, pp. 198-201.

Kamber, B.S., Ewart, A., Collersin, K.D., Bruce, M.C., McDonald, G.D., 2002. Fluid-mobile trace elemento constraints on the role of slab melting and implications for Archean crustal growth models. Contributions to Mineralogy and Petrology 144, 38-56.

Kay, R.W., Kay, S.M., 2002. Andean adakites: three ways to make them. Acta Petrologica Sinica 18, 303-311.

Kelemen, P.B., Hanghøj, K., Greene, A.R., 2003. One View of the Geochemistry of Subduction-Related Magmatic Arcs, with Emphasis on Primitive Andesite and Lower Crust. Treatise on Geochemistry, 3. Elsevier, pp. 593-659.

Kepezhinskas, P., Defant, M.J. and Drummond, M.S., 1995. Na metasomatism in the island.arc mantle by slab melt-peridotite interaction: evidence from mantle xenoliths in the North Kamchatka Arc. Journal of Petrology 36, 1505-1527.

Kepezhinskas, P., Defant, M.J. and Drummond, M.S., 1996. Progressive enrichment of island arc mantle by melt-peridotite interaction inferred from Kamchatka xenoliths. Geochimica Cosmochimica Acta 60, 1217-1229.

Kerr, A.C., Tarney, J., Marriner, G.F., Nivia, A., Saunders, A.D., 1997. The CaribbeanColumbian cretaceous igneous province: the internal anatomay of na oceanic plateau. In: Mahoney, J.J., Coffin, M. (Eds.), Large Igneous Provinces: Continental, Oceanic, and Planetary Flood Volcanism. AGU Geophysical Monographs, vol. 100, pp. 123-144.

Kerrich, R. and Fryer, B.J., 1979. Archean precious metal hydrothermal systems Dome Mine, Abitibi greenstone belt. II. REE and oxygen isotope relations. Canadian Journal of Earth Sciences 16, 440-458.

Kerrich, R., Wyman, D.A., Fan, J. and Bleeker, W., 1998. Boninite series: low-Ti tholeiite associations from the $2.7 \mathrm{Ga}$ Abitibi greenstone belt. Earth Planetary Science Letters 164, 303-316.

Kerrich, R. and Manikyamba, C., 2012. Contemporaneous eruption of Nb-enriched basalts-Kadakites-Na-adakites from the $2.7 \mathrm{Ga}$ Penakacherla terrane: implications for the subduction zone processes and crustal growth in the eastern Dharwar craton, India.Canadian Journal of Earth Sciences 49, 615-636. 
Khanna, T.C., Sesha Sai, V.V., Bizimis, M., Krishna, A.K., 2015. Petrogenesis of basalt-high$\mathrm{Mg}$ andesite-adakite in the Neoarchean Veligallu greenstone terrane: Geochemical evidence for a rifted back-arc crust in the eastern Dharwar craton, India. Precambrian Research 258, 260-277.

Klötzli, U., Klötzli, E., Günes, Z., Košler, J., 2009. Accuracy of Laser Ablation U-Pb Zircon Dating: Results from a Test Using Five Different Reference Zircons. Geostandards Geoanalytical Research 33, 5-15.

Kopp, R.E., Kirschvink, J.L., Hilburn, I.A., Nash, C.Z., 2005. The Paleoproterozoic snowball Earth: A climate disaster triggered by the evolution of oxygenic photosynthesis. Proceedings of the National Academy of Sciences of the United States of America 102, 11131-11136.

Kusky, T.M., Windley, B.F., Safonova, I., Wakita, K., Wakabayashi, J., Polat, A., Santosh, M., 2013. Recognition of ocean plate stratigraphy in accretionary orogens through Earth history: a record of 3.8 billion years of sea floor spreading, subduction, and accretion. Gondwana Research 24, 501-547.

Kuyumjian, R. M. \& Teixeira, N. A., 1982. Um novo tipo de estrutura em lavas ultramáficas: greenstone belt de Crixás, GO. Revista Brasileira de Geociências 12, 572-577.

Laux, J.H., Pimentel, M.M., Dantas, E.L., Armstrong, R., Junges, S.L., 2005. Two neoproterozoic crustal accretion events in the Brasília Belt, central Brazil. Journal of South American Earth Sciences 18, 183-198.

Ludden, J.N., Gélinas, L., Trudel, P., 1982. Archean metavolcanic from the Rouyn-Noranda district, Abitibi greenstone belt, Québec. 2. Mobility of trace elements and petrogenetic constraints. Canadian Journal of Earth Sciences 19, 2276-2287.

Ludwig, K.R., 2003. User's Manual for Isoplot/Ex version 3.00-A Geochronology Toolkit for Microsoft Excel, No. 4. Berkeley Geochronological Center Special Publication, 70 pp.

Mahoney, J.J., Jones, W.B., Freu, F.A., Salters, V.J.M., Pyle, D.G., Davies, H.L., 1995. Geochemical characteristics of lavas from Broken Ridge, the Naturaliste Plateau and southernmost Kerguielen Plateau: Cretaceous plateau volcanism in the southeast India Ocean. Chemical Geology 120, 315-345.

Manikyamba, C., Khanna, T.C., 2007. Crustal growth processes as illustrated by the Neoarchaean intraoceanic magmatism from Gadwal greenstone belt, Eastern Dhawar Craton, India. Gondwana Research 11, 476-491.

Manikyamba, C., Kerrich, R., Khanna, T.C., Subba Rao, D.V., 2007. Geochemistry of adakites and rhyolites from Gadwal greenstone belt, India: implications on their tectonic setting. Canadian Journal of Science 44, 1517-1535.

Manikyamba, C., Kerrich, R., Khanna, T.C., Satyanarayanan, M., Krishna, A.K., 2009. Enriched and depleted arc basalts, with high-Mg andesites and adakites: a potential paired 
arc-backarc of the 2.7 Ga Hutti greenstone terrane, India. Geochimica Cosmochimica Acta 73, 1711-1736.

Martin, H., Chauvel, C., Jahn, B.M., 1983. Major and trace element geochemistry and crustal evolution of granodioritic Archaean rocks from eastern Finland. Precambrian Research 21, 159-180.

Martin, H., 1987. Petrogenesis of Archaean trondhjemites, tonalites and granodiorites from eastern Finland: major and trace element geochemistry. Journal of Petrology 28 (5), 921-953.

Martin, H., 1999. The adakitic magmas: modern analogues of Archaean granitois. Lithos 46 (3), 411-429.

Martin, H., Smithies, R.H., Rapp, R., Moyen, J.-F., Champion, D., 2005. Na overview of adakite, tonalite-trondhjemite-granodiorite (TTG), and sanukitoid: relationships and some implications for crustal evolution. Lithos 79, 1-24.

McCulloch M.T., Gamble, A.J., 1991. Geochemical and geodynamical constraints on subduction zone magmatism. Earth Planetary Science Letters 102, 358-374.

Melezhik, V.A., Huhma, H., Condon, D.J., Fallick, A.E., Whitehouse, M.J., 2007. Temporal constraints on the Paleoproterozoic Lomagundi-Jatuli carbon isotopic event. Geology 35, 655.

Middlemost, E.A.K., 1994. Naming materials in magma/igneous rock system. Earth Science Reviews 37, 215-224.

Moraes, R. de \& Fuck, R.A., 2000. Ultra-high-temperature metamorphism in Central Brazil: the Barro Alto complex. Journal of Metamorphic Geology 18 (4), 345-358.

Murphy, J.B., Hynes, A.J., 1986. Contrasting secondary mobility of Ti, P, Zr, Nb and Y in two metabasaltic suítes in the Appalachians. Canadian Journal of Earth Sciences 23, 11381144.

Nestbitt, R.W., Sun, S.S., Purvis, A.C., 1979. Komatiites: Geochemistry and Genesis. Can. Mineral 17, 165-186.

Parman, S.W., Grove, T.L., Dann J.C., 2001. The production of Barberton komatiites in an Archean subduction zone. Geophysical Research Letters 28, 2513-2516.

Parman, S.W., Grove, T.L., 2004. Petrology and geochemistry of Barberton komatiites and basaltic komatiites: evidences of Archean fore-arc magmatism. In: Kusky, T.M. (Ed.), Precambrian Ophiolites and Related Rocks. Developments in Precambrian Geology, vol. 13, pp. 539-565.

Parman, S.W., Grove, T.L., Dann, J.C., De Wit, M.J., 2004. A subduction origin for komatiites and cratonic lithospheric mantle. South African Journal of Geology 107, 107-118.

Pearce, J.A., 1982. Trace element characteristics of lavas from the destructive plate boundaries. In: Thorpe, R.S. (Ed.), Andesites. John Wiley and Sons, pp. 525-548. 
Pearce, J.A., 2003. Supra-subduction zone ophiolites: the search for modern analogues. In: Dilek, Y., Newcomb, S. (Eds.), Ophiolite Concept and the Evolution of Geological Thought.

Pearce, J.A., 2008. Geochemical fingerprinting of oceanic basalts with applications to ophiolite classification and the search for Archean oceanic crust. Lithos 100, 14-48.

Pearce, J.A., 2014. Geochemical fingerprinting of the Earth's oldest rocks. Geology 42, 175 176. Geological Society of America Special Paper 373, pp. 269-293.

Pearce, J.A., Peate, D.W., 1995. Tectonic implications of the composition of volcanic arc magmas. Annual Review of Earth and Planetary Sciences 23, 251-285.

Pearce, J.A., Thirlwall, M.F., Ingram, G., Murton, B.J., Arculus, R.J., Van der Laan, S.R., 1992. Isotopic evidence for the origin of boninites and related rocks drilled in the Izu-Bonin (Ogasawara) foreac, Leg 125. In: Fryer, P., Pearce, J.A., Stokking, L.B. et al. Proceedings of the Ocean Drilling Program, Scientific Results 125, 237-261.

Pearce, J.A., Sterm, R.J., Bloomer, S.H., Fryer, P., 2005. Geochemical mapping of the Mariana arc-basin system: implications for the nature and distribution of subduction componentes. Geochem. Geophys. Geosyst. 6, 2004GC000895.

Perfit, M.R., Gust, D.A., Bence, A.E., Arculus, R.J., Taylor, S., 1980. Geochemical characteristics of island.-arc basalts: implications of mantle sources. Chemical Geology 30, 227-256.

Percival, J.A., Stern, R.A., Rayner, N., 2003. Archean adakites from the Ashuanipi complex, eastern Superior Province, Canada: geochemistry, geochronology, and tectonic significance. Contribution to Mineralogy and Petrology 145, 265-280.

Pimentel, M.M., Heaman, L., Fuck, R.A., 1991. U-Pb zircon and sphene geochronology of late Proterozoic volcanic arc rock units from southwestern Goiás, central Brazil. Journal of South American Earth Sciences 4, 329-339.

Pimentel, M.M. and Fuck, R.A., 1992. Neoproterozoic crustal accretion in Central Brazil. Nature 20 (4), 375-379.

Pimentel, M.M., Whitehouse, M.J., Vianna, M.G., Fuck, R.A., Machado, N., 1997. The Mara Rosa arc in the Tocantins Province: further evidence for Neoproterozoic crustal accretion in central Brazil. Precambrian Research 81, 299-310.

Pimentel, M.M., Fuck, R.A., Jost, H., Ferreira Filho, C.F., Araújo, S.M., 2000. The basement of the Brasilia Fold Belt and Goiás Magmatic Arc. In: Cordani, U.G., Milani, E.J., Thomaz Filho, A., Campos, D.A. (Eds.), Tectonic Evolution of South America, 31st International Geological Congress, pp. 195-230.

Pimentel, M.M., Jost, H., Fuck, R.A., Armstrong, R.A., Dantas, E.L., Potrel, A., 2003. Neoproterozoic anatexis of $2.9 \mathrm{Ga}$ old granitoids in the Goiás-Crixás block, Central Brazil: 
evidence from new SHRIMP U-Pb data and Sm-Nd isotopes. Geologia USP, Série Científica $3,1-12$.

Pimentel, M.M., Jost, H., Fuck, R.A., 2004. O embasamento da Faixa Brasília e o Arco Magmático de Goiás. In: Mantesso-Neto, V., Bartorelli, A., Carneiro, C.D.R., Neves, B.B.B. (Eds.), Geologia do Continente Sul-Americano: evolução da obra de Fernando Fávio Marques de Almeida. Beca Produções Culturais Ltda, São Paulo, pp. 356-368.

Piuzana, D., Pimentel, M.M., Fuck, R.A., Armstrong, R., 2003 Neoproterozoic magmatism and high-grade metamorphism in the Brasília Belt, central Brazil: regional implications of SHRIMP U-Pb and Sm-Nd geochronological studies. Precambrian Research 125, 245-273.

Polat, A., Kerrich, R., Wyman, D.A., 1998. The late Archean Schreiber-Hemlo and White River-Doyohessarah greenstone belts. Superior Province: collages of oceanic plateaus, oceanic arcs, and subduction-accretion complexes. Tectono-physics 289, 295-326.

Polat, A., Hofmann, A.W., 2003. Alteration and geochemical patterns in the 3.7-3.8 Ga Isua greenstone belt, West Greenland. Precambrian Research 126, 197-218.

Polat, A., Kerrich, R., 2000. Archean greenstone magmatism and the continental growthmantle evolution connection: constraints from Th-U-Nb-LREE systematics of the $2.7 \mathrm{Ga}$ Wawa subprovince, Superior Province, Canada. Earth Planetary Science Letters 175, 41-54.

Polat, A., Kerrich, R., 2001. Magnesian andesites, Nb-enriched basalt-andesites, and adakites from late Archean $2.7 \mathrm{Ga}$ Wawa greenstone belts, Superior Province, Canada: Implications for late Archean subduction zone petrogenetic processes. Contribution to Mineralogy and Petrology 141, 36-52.

Polat, A., Kerrich, R., 2004. Precambrian arc associations: boninites, adakites, magnesian andesites, and Nb-enriched basalts. In: T.M. Kusky (Ed.), Precambrian Ophiolites and Related Rocks, Amsterdam, pp. 567-597.

Polat, A., Kerrich, R., 2006. Reading the geochemical fingerprints of Archean hot subduction volcanic rocks: evidence for accretion and crustal recycling in a mobile tectonic regime. In: Benn, K., Mareschal, J.C., Condie, K.C. (Eds.), Archean Geodynamics and Environments. AGU Geophysics Monograph Series, 164. 189-213.

Polat, A., 2009. The geochemistry of Neoarchean (ca. $2700 \mathrm{Ma}$ ) tholeiitic basalts, transitional to alcaline basalts, and gabbros, Wawa Subprovince, Canada: Implications for petrogenetic and geodynamic processes. Precambrian Research 168, 83-105.

Profumo, J.J.L., 1993. Alteração hidrotermal das rochas ultramáficas e máficas do greenstone belt de Goias Velho (GO). Dissertação de Mestrado, Instituto de Geociências, Universidade de Brasília, Brasília, 143 pp.

Prouteau, G., Scaillet, B., Pichavant, M., Maury, R., 2001. Evidence for mantle metasomatism by hydrous silicic melts derived from subducted oceanic crust. Nature 410, 197-200. 
Puchtel, I.S., Hofmann, A.W., Mezger, K., Jochum, P.K., Scipansky, A.A., Samsanov, A.V., 1998. Oceanic plateau model for continental crustal growth in the Archean: a case study from the Kostomuksha greenstone belt, NW Baltic Shield. Earth Planetary Science Letters 155, 57 74.

Queiroz, C.L., 2000. Evolução Tectono-Estrutural dos Terrenos Granito-Greenstone Belt de Crixás, Brasil Central. Tese de Doutorado, Instituto de Geociências, Universidade de Brasília, $209 \mathrm{pp}$.

Queiroz, C.L., Jost, H., Silva, L.C., McNaughton, N.J., 2008. U-Pb SHRIMP and Sm-Nd geochronology of granite-gneiss complexes and implications for the evolution of the central Brazil Archean terrain. Journal of South American Earth Sciences 26, 100-124.

Rapp, R.P., Shimizu, N., Norman, M.D., Applegate, G.S., 1999. Reaction between slabderived melts and peridotite in the mantle wedge: experimental constraints at $3.8 \mathrm{GPa}$. Chemical Geology 160, 335-356.

Regan, M.K., Gill, J.B., 1989. Coexisting calc-alkaline and high-niobium basalts from Turrialba volcano,Costa Rita: implications for residual titanates in arc magma sources. Journal of Geophysical Research 94, 4619-4633.

Resende, M.G. \& Jost, H., 1994. Redefinição da Formação Aimbé, greenstone belt de Guarinos, Goiás, e sua interpretação paleogeográfica e paleotectônica. Boletim de Geociências do Centro-Oeste 17, 49-56.

Resende, M.G. \& Jost, H., 1995a. Petrogênese de formações ferríferas e metahidrotermalitos da Formação Aimbé, Grupo Guarinos (Arqueano), Goiás. Revista Brasileira de Geociências $25,41-50$.

Resende, L. \& Jost, H., 1995b. Características estratigráficas e petrográficas da sequência metassedimentar do greenstone belt de Pilar de Goiás. SBG Goiânia, Revista Brasileira de Geociências do Centro-Oeste 18 (1/2), 66-83.

Resende, M.G., Jost, H., Osborne, G. A., Mol, A. G., 1998. Stratigraphy of the Goiás and Faina greenstone belts, Central Brazil: a new proposal. Revista Brasileira de Geologia 28, 77 94.

Resende, M.G., Jost, H., Lima, B.E.M., Teixeira, A.A., 1999. Proveniência e idades-modelo Sm-Nd de rochas siliciclásticas arqueanas dos greenstone belts de Faina e Santa Rita, Goiás. Revista Brasileira de Geologia 29, 281-290.

Rodrigues, V.G., 2011. Geologia do depósito aurífero do Caiamar, greenstone belt de Guarinos: um raro depósito associado a albitito sódico. Dissertação de Mestrado, Instituto de Geociências, Universidade de Brasília, Brasília, 79 pp.

Ross, P.-S., and Bédard, J.H., 2009. Magmatic affinity of modern and ancient subalkaline volcanic rocks determined from trace-element discriminant diagrams. Canadian Journal of Earth Sciences 46, 823-839. 
Sabóia, L.A., 1979. Os greenstone belts de Crixás e Goiás, GO. SBG, Núcleo Centro-Oeste, Boletim Informativo 9, 44-72.

Sajona, F.G., Maury, R.C., Bellon, H., Cotton, J. and Defant, M.J., 1996. High field strenght elements enrichment of Pliocene-Pleistocene island arc basalts, Zamboanga Peninsula, Western Mindanao (Philippines). Journal of Petrology 37, 693-726.

Santos R.V., Oliveira C.G., Souza V.H.V., Carvalho M.J., Andrade T.V., Souza H.G.A. 2008. Correlação isotópica baseada em isótopos de Carbono entre os greenstone belts de Goiás. In: SBG, Congr. Bras. Geol., 44, Curitiba, Volume de Resumos, pg. 52.

Santos, M, M., 2015. Deesenvolvimento de padrões de zircão para geocronologia U-Pb e análises isotópicas de Hf por Laser Abaltion ICP-MS. Dissertação de Mestrado, UFOP, Ouro Preto, $115 \mathrm{p}$.

Saunders, A.D., Norry, M.J., Tarney, J., 1988. Origin of MORB and chemically-depleted mantle reservoirs: trace element constraints. Journal of Petrology (Special Lithosphere Issue), 415-445.

Saunders, A.D., Norry, M.J., Tarney, J., 1991. Fluid influence on the trace element compositions of subduction zone magmas. Philosophical transactions: physical sciences and engineering. Royal Society of London 335, 377-392.

Seer, H.J., Brod, A.J.A., Fuck, R.A., Pimentel, M.M., Boaventura, G.R., Dardenne, M.A., 2001. Grupo Araxá em sua área tipo: um fragmento de crosta oceânica neoproterozóica na Faixa de Dobramentos Brasília. Revista Brasileira de Geociências 31 (3), 385-396.

Sen, C. and Dunn, T., 1994. Experimental modal metasomatism of a spinel lherzolite and the production of amphibole-bearing peridotite. Contribution to Mineralogy and Petrology 119, 422-432.

Sláma, J., Košler, J., Condon, D.J., Crowley, J.L., Gerdes, A., Hanchar, J.M., Horstwood, M.S.A., Morris, G.A., Nasdala, L., Norberg, N., Schaltegger, U., Schoene, B., Tubrett, M.N., Whitehouse, M.J., 2008. Plešovice zircon - a new natural reference material for U-Pb and $\mathrm{Hf}$ isotopic microanalysis. Chemical Geology 249, 1-35.

Shchinpasky, A.A., Samsonov, A.V., Bibikova, E.V., Babarina, I.I., Konilov, A.N., Slabunov, A.I., Bogina, M.M., 2004. Boninite hosting partial subduction zone ophiolite sequences from the north Karelian greenstone belt, NE Baltic Shield, Russia. In: Kusky, T.M. (Ed.), Precambrian Ophiolites and Related Rocks. Elsevier, Amsterdam, pp. 425-486.

Shirey, S.B., Hanson, G.N., 1984. Mantle derived Archaean monzodiorites and trachyandesites. Nature 310, 222-224.

Strieder, A. and Nilson, A.A., 1992. Melange Ofiolítica nos Metassedimentos Araxá de Abadiânia (GO) e Implicações Tectônicas Regionais. Revista Brasileira de Geociências 22 (2), 204-215. 
Smithies, R.H., Champion, D.C., Van Kranendonk, M.J., Howard, H.M., Hickman, A.H., 2005. Modern-style subduction processes in the Mesoarchaean: geochemical evidence from the 3.12 Ga Whundo intraoceanic arc. Earth and Planetary Science Letters 231, 221-237.

Sun, S.S., McDonough, W.F., 1989. Chemical and Isotopic systematics of oceanic basalts, implications for mantle composition and processes. In: Saunders, A.D., Norry, M.J. (Eds.), Magmatism in the Ocean Basins. Geological Society of London Special Publication 42. Blackwell Scientific Publication, UK, pp. 313-345.

Tassinari, C.C.G., Jost, H., Santos, J.C., Nutman, A.P., Bennell, M.R., 2006. Pb and Nd isotope signatures and SHRIMP U-Pb geochronological evidence of paleoproterozoic age for Mina III gold mineralization, Crixás District, Central Brazil. 5th South American Symposium on Isotope Geology, Punta Del Este, Uruguay, Short Papers Volume pp. 527-529.

Tatsumi, Y. and Ishizaka, K., 1982. Magnesian andesite and basalt from Shodo-Shima Island, southwest Japan, and their bearing on the genesis of calc-alkaline. Litho 15, 161-172.

Tatsumi, Y. and Nakamura, N., 1986. Composition of aqueous fluid from serpentinite in the subducted lithosphere. Geochemical Journal 20, 191-196.

Tatsumi, Y., Hamilton, D.L. and Nesbitt, R.W., 1986. Chemical characteristics of fluid phase released from a subducted lithosphere and origin of arc magmas: evidence from high-pressure experiments and natural rocks. Journal of Volcanology and Geothermal Research 29, 293309.

Taylor, S.R., McLennan, S.M., 1985. The Continental Crust: its Composition and Evolution. Blackwell, Oxford, pp. 312.

Teixeira, A.S., 1981. Geologia da região de Goiás-Faina. SBG, Simpósio Geologia CentroOeste, Atas, Goiânia, pp. 344-360.

Teixeira, N.A., Saboia, L.A., Ferreira, M.C.B., Teixeira, A.S., Castro, J.H.G., 1981. Estruturas e texturas das lavas ultrabásicas e básicas do greenstone belt de Crixás, Goiás, Brasil. SBG, Núcleo do Centro-Oeste, Boletim Informativo 10, 33-87.

Toledo, C.L.B., Silva, A.M. et al., 2014. Projeto Faina-Goás: Mapeamento geológico em escala 1:25.000 dos greenstone belts Faina e Serra de Santa Rita.

Ujike, O., Goodwin, A.M., Shibata, T., 2007. Geochemistry and origin of Archean volcanic rocks from the Upper Keewantin assemblage (ca. 2.7 Ga), Lake of the Woods Greenstone Belt, Western Wabigoon Subprovince, Superior Province, Canada. Island Arc 16, 191-207.

Xie, Q., Kerrich, R. and Fan, J., 1993. HFSE/REE fractionations recorded in the three komatite-basalt sequence, Archean Abititi belt: implications for multiple plume sources and depht. Geochimica Cosmochimica Acta 57, 4111-4118. 
Yogodzinski, G.M., Volynets, O.N., Koloskov, A.V., Matvenkov, V.V., 1994. Magnesian andesites and subduction component in a strongly calc-alkaline series at Piip volcano, far western Aleutians. Journal of Petrology 35, 163-204.

Wade, J.A., Plank, T., Stern, R.J., Tollstrup, D.L., Gill, J.B., O Leary, J.C., J.M., Moore, R.B., Woodhead., J.D., Trusdell, F.A., Fischer, T.P., Hilton, D.R., 2005. The May 2003 eruption of Anatahan Volcano, Mariana Islands: geochemical evolution of a silicic Island-Arc volcano. Journal of Volcanology and Geothermal Research 146, 139-170.

Wang, Q., Xu, J.F., Jian, P., Bao, Z.W., Zhao, Z.H., Li, C.F., Xiong, X.L., Ma, J.L., 2006. Petrogenesis of adakitic porphyries in an extensional tectonic setting, Dexing, South China: implications for the genesis of porphyry copper mineralization. Journal of Petrology 47, 119144.

Wang, Q., Wyman, D.A., Xu, J.F., Jian, P., Zhao, Z.H., Li, C.F., Xu, W., Ma, J.L., He, B., 2007. Early Cretaceous adakitic granites in the Northern Dabie Complex, central China: implications for partial melting and delamination of thickened lower crust. Geochimica et Cosmochimica Acta 71, 2609-2636.

Wiedenbeck, M., Allé, P., Corfu, F., Griffin, W.L., Meier, M., Oberli, F., Von Quadt A., Roddick, J.C., Spiegel W., 1995. Three natural zircon standards for U-Th-Pb, Lu-Hf, trace element and REE analyses. Geostandards Newsletter 19, 1-23.

Winchester, J.A. and Floyd, P.A., 1977. Geochemical discrimination of different magma series and their differentiation products using immobile elements. Chemical Geology 20, 325343.

Wyman, D.A., Ayer, J.A., J.R. Devaney, J.R., 2000. Niobium-enriched basalts from the Wabigoon subprovince, Canada: evidence for adakitic metasomatism above na Archean subduction zone. Earth Planetary Science Letters 179, 21-30. 